\title{
Japan: IOSCO Objectives and Principles of Securities Regulation- Detailed Assessment of Implementation
}

This paper was prepared based on the information available at the time it was completed in August, 2012. The views expressed in this document are those of the staff team and do not necessarily reflect the views of the government of Japan or the Executive Board of the IMF.

The policy of publication of staff reports and other documents by the IMF allows for the deletion of market-sensitive information.

\author{
Copies of this report are available to the public from \\ International Monetary Fund • Publication Services \\ $70019^{\text {th }}$ Street, N.W. • Washington, D.C. 20431 \\ Telephone: (202) 623-7430 • Telefax: (202) 623-7201 \\ E-mail: publications@imf.org Internet: http://www.imf.org
}

\section{International Monetary Fund Washington, D.C.}


FinANCIAL SECTOR ASSESSMENT PROGRAM

\section{JAPAN}

IOSCO OBJECTIVES AND PRINCIPLES OF SECURITIES

REGULATION

DETAILED ASSESSMENT OF

IMPLEMENTATION

August 2012

INTERNATIONAL MONETARY FUND

MONETARY AND CAPITAL MARKETS DEPARTMENT 


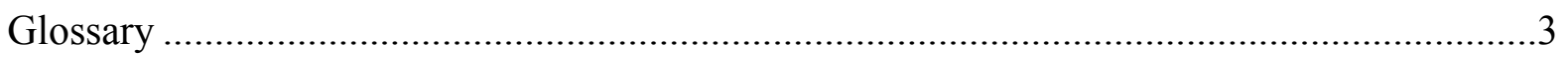

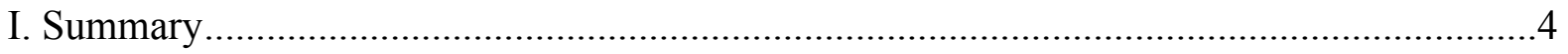

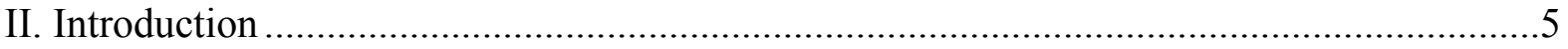

III. Information and Methodology Used for the Assessment ……...........................................5

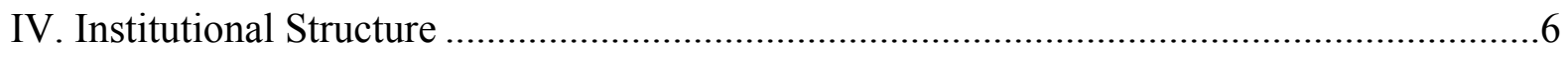

V. Basic Legal Framework for Market Participants .................................................................

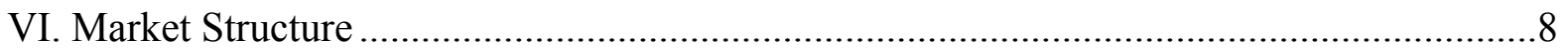

VII. Preconditions for effective securities regulation .........................................................10

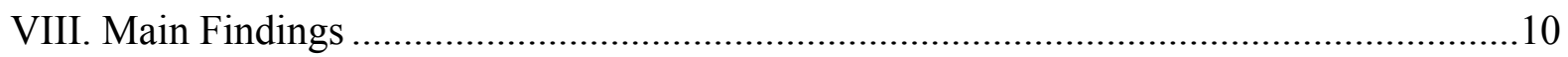

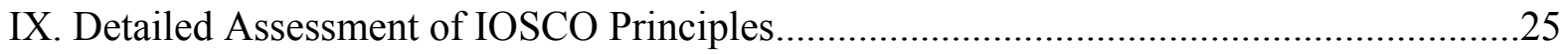

Tables

1. Summary Implementation of the IOSCO Principles-Detailed Assessments ....................13

2. Recommended Action Plan to Improve Implementation of the IOSCO Principles .............22

3. Detailed Assessment of the Implementation of the IOSCO Principles ................................26 


\section{GLOSSARY}

ADR

ASBJ

BAC

BOJ

CIS

CPA

CPAA

CPAAOB

DICJ

FIBO

FIEA

GAAP

IMBO

IOSCO

ITAJ

ITIC

JSDA

JSIAA

OSBM

OSE

OTC

$\mathrm{MoF}$

MoFS

$\mathrm{MoU}$

MMoU

NAV

PM

PTS

SESC

SRO

TSE

Type II FIA
Alternative Dispute Resolution

Accounting Standards Board of Japan

Business Accounting Council

Bank of Japan

Collective Investment Schemes

Certified Public Accountant

Certified Public Accountant Act

Certified Public Accounting and Auditing Oversight Board

Deposit Insurance Corporation of Japan

Financial Instruments Business Operator

Financial Instruments Exchange Act

Generally Accepted Accounting Principles

Investment Management Business Operator

International Organization of Securities Commissions

Investment Trust Association of Japan

Investment Trust and Investment Corporations Act

Japan Securities Dealers Association

Japan Securities Investment Advisers Association

Office of Securities Business Monitoring

Osaka Stock Exchange

Over the counter

Minister of Finance

Minister of Financial Services

Memorandum of Understanding

IOSCO Multilateral Memorandum of Understanding

Net Asset Value

Prime Minister

Proprietary Trading System

Securities Exchange and Surveillance Commission

Self Regulatory Organization

Tokyo Stock Exchange

Type II Financial Instruments Association 


\section{SUMmary}

1. The legal and regulatory framework for the securities market in Japan exhibits a high level of implementation of the International Organization of Securities Commissions (IOSCO) Principles. In particular, there is a robust legal framework that provides extensive powers to the Financial Services Agency (FSA) to supervise regulated entities, to investigate breaches of securities laws and regulations, as well as to cooperate both domestically and internationally. In addition, the FSA has made changes in its organizational structure to upgrade its capacity to identify, monitor, and mitigate systemic risk.

2. However, ongoing supervision of securities firms should be strengthened. First, the FSA should develop a more robust framework to identify and assess the scale and scope of risk posed by individual firms that could also serve as a tool to determine the intensity of regulatory intervention (including on-site inspections). Vis-á-vis investor protection, the Securities Exchange and Surveillance Commission (SESC) should intensify the coverage of its inspection program for smaller firms, as conduct issues cannot be easily captured through off-site reporting. This could be accomplished through a combination of additional institution-based inspections, thematic reviews, and/or random inspections.

3. In addition, the FSA should consider reviewing its enforcement program to ensure proper balance between different type of regulatory measures at its disposal, from orders for improvement to suspensions and cancellations of registration. Also, the authorities should consider reviewing the current framework for administrative money penalties to (i) ensure that the amount of the penalties is sufficient to ensure a deterrent effect; as well as (ii) to expand the type of misconducts to which administrative money penalties could be applied.

4. From an organizational perspective, FSA governance arrangements and resources should continue to be strengthened. Mechanisms should be explored to ensure that the FSA can hire and retain expert staff across the different departments of the organization, including for example by reviewing the salary scale. In this context, the FSA should review whether current resources are sufficient to ensure the robustness of its supervisory program. The authorities should also explore ways to enhance FSA legal independence.

5. Finally, efforts to implement the new principles should continue, in particular in connection with the identification of emerging and systemic risk. The creation of the Office of Securities Business Monitoring (OSBM) is a step in the right direction. However, it is important that some type of arrangement be in place to more comprehensively and systematically identify and assess risks and determine the need for regulatory intervention. 


\section{INTRODUCTION}

6. An assessment of the level of implementation of the IOSCO Principles in the Japanese securities market was conducted from November 28-December 16, 2011, as part of the Financial Sector Assessment Program (FSAP) by Ms. Ana Carvajal, Monetary and Capital Markets Department (MCM) and Mr. Martin Kinsky (external expert). An initial IOSCO assessment was conducted in 2003. Since then, significant changes have taken place in the Japanese market, in terms of market development and upgrading of the regulatory framework. In addition, IOSCO approved a new set of principles in 2010, and a revised methodology in 2011.

\section{INFORMATION AND METHODOLOGY USED FOR THE ASSESSMENT}

7. The assessment was conducted based on the IOSCO Principles and Objectives of Securities Regulation approved in 2010, and the methodology adopted in 2011. As has been the standard practice, Principle 38 was not assessed due to the existence of a separate standard for securities settlement systems. A technical note on the oversight framework for systemically important financial market infrastructures was delivered during this mission. The assessment did not cover commodities derivatives exchanges or other derivatives exchanges where the underlying asset is not a security.

8. The IOSCO methodology requires that assessors not only look at the legal and regulatory framework in place, but at how it has been implemented in practice. The recent global financial crisis has reinforced the need for assessors to take a critical look at and to make a judgment about supervisory practices, to determine whether they are effective enough. Among others, such a judgment involves a review of the inspection programs for different types of intermediaries, the cycle, scope and quality of inspections as well as how the agency follows-up on findings, including the use of enforcement actions.

9. The assessors relied on: (i) a self-assessment developed by the FSA; (ii) the review of relevant laws and reports available in English; (iii) meetings with staff from the FSA, the SESC, the Certified Public Accounting and Auditing Oversight Board (CPAAOB), and the Bank of Japan (BOJ); as well as (iv) meetings with market participants, including issuers, securities firms, fund managers, exchanges, external auditors, credit rating agencies, the Japanese Securities Dealers Association (JSDA), the Investment Trust Association of Japan (ITAJ), the Japanese Institute of Certified Public Accountants (JICPA), and law firms. The limited availability of information in English was a challenge; however, to some extent, gaps were filled through the discussions with the authorities and market participants, although review of supervisory files could not be conducted in an optimal manner.

10. The assessors want to thank the FSA and the BOJ for their full cooperation as well as their willingness to engage in very candid conversations regarding the regulatory and supervisory framework in Japan. The assessors also want to extend their appreciation to all other public authorities and market participants with whom they met. 


\section{InSTITUTIONAL STRUCTURE}

11. The regulation and supervision of the Japanese securities markets are responsibilities of the FSA, SESC, and the CPAAOB. The nature of these entities differs: the FSA is an agency within the Cabinet, while the SESC and the CPAAOB are boards within the FSA, but to which the Financial Instruments Exchange Act (FIEA) afforded a high degree of independence vis-à-vis the FSA.

\section{These agencies exercise delegated authority, as the responsibility for regulation} and supervision of securities markets is assigned to the Prime Minister (PM) by the FIEA. Such act delegates all authority and functions in connection with the regulation and supervision of securities markets to the FSA except functions excluded by a Cabinet Ordinance. Current exceptions are limited, mostly circumscribed to the licensing of exchanges and the authorization of associations. The FIEA prescribes a second level of delegation, in this case of the authority of the FSA in the SESC, to which it entrusts the authority to request reports from regulated entities and conduct on-site inspections and investigations. Finally, the CPA Act delegates to the CPAAOB the oversight of auditors. From an operational perspective responsibilities are distributed as follows-the FSA is responsible for policy, off-site monitoring, and imposition of enforcement actions. The SESC carries out onsite inspections and investigations. Based on the results, the SESC may make a recommendation on enforcement actions to the FSA. The CPAAOB oversees the quality control program developed by JICPA, carries out inspections on auditors, and as a result of such inspections, the CPAAOB may make a recommendation for enforcement actions to the FSA.

13. A third level of delegation is to the local finance bureaus. The FIEA authorizes the FSA and the SESC to delegate their monitoring and inspection functions to the local finance bureaus. In practice, the FSA and the SESC entrust to the local finance bureaus the review of prospectus and periodic information of issuers; the review of tender offer documents; the registration of financial instruments business operators (FIBOs); and the off-site monitoring and on-site inspections of FIBOs whose capital is less than $¥ 12$ billion.

\section{Several types of self regulatory organizations (SROs) coexist and perform}

important self regulatory functions. Pursuant to the FIEA, three different types of entities can perform self regulatory functions: the exchanges, associations and SROs, which are entities that can only be constituted by exchanges. In practice in addition to the exchanges, there are several more entities performing important SRO functions-the Tokyo Stock Exchange (TSE) SRO, the JSDA, and the ITAJ. There are two more associations- the Japan Securities Investment Advisers Association (JSIAA) and the Type II Financial Instruments Firms Association (Type II FIA). The JSIAA has some rulemaking functions in connection with investment advisers, and has subject them to off-site reporting; however it does not conduct on-site inspections on them nor exercise enforcement functions-although it can withdraw membership. Finally the Type II FIA has self regulatory functions in connection 
with Type II FIBOs; but is of very recent creation. Therefore this assessment has not covered these two associations.

\section{BASic Legal Framework for MARKet Participants}

\section{The main laws applicable to securities markets are the Financial Instruments} Exchange Act (FIEA) and the Investment Trust and Investment Corporations Act (ITIC).

16. Issuers of securities that are offered to the public are required to notify the FSA and file a registration statement. They are also required to submit an annual report, and either a quarterly report (for listed issuers) or a semiannual report (for non-listed issuers). Issuers are also required to notify a list of corporate events to the FSA. In addition, the TSE has established a principle of timely disclosure of corporate actions which requires disclosure to the exchange of any event that could have a material effect on investors' decisions.

\section{Collective Investment Schemes (CIS) that are offered to the public are also} required to file their offering documents with the FSA. CIS can be constituted as trusts or corporations, in both cases the law requires that they be managed by a financial instruments business operator (FIBO) registered as an investment management business operator (IMBO).

\section{The provision of securities activities in Japan requires registration as a FIBO.}

There are four main types of FIBOs: Type I, which is essentially a broker dealer which can trade in a wide array of securities including stocks, bonds, shares of CIS, derivatives, etc.; Type II, which is a broker-dealer that can only trade in a very limited category of securities (those not included in the list of authorized securities for Type I and which are commonly referred to as "illiquid" securities); IMBO which is an asset manager; and an investment advisory firm, which can provide investment advisory services. Registered financial institutions (such as banks, cooperatives, and insurance companies) can also provide a limit number of securities markets services to retail investors, mainly related to the distribution of government debt and CIS. The FSA has established a system of consolidated supervision for securities firms with assets equal or above $¥ 1$ trillion.

19. Two different types of regulated markets coexist: exchanges and proprietary trading facilities (PTS). Exchanges require a license which is granted by the MoFS on behalf of the PM (PM) while Proprietary Trading System (PTS) must be registered as a Type I FIBO. A trading volume limit of 10 percent is set up on PTS (Article 1 of the Cabinet Order for Enforcement of the FIEA). 


\section{MARKet Structure}

\section{Equity markets}

20. A total of 2,900 companies are listed on any of the six exchanges that operate in Japan. Out of such number, 2,280 were listed on the Tokyo Stock Exchange (TSE). The TSE is the main equity exchange in Japan, with a market capitalization of roughly US\$3,634,790 million as of March 31, 2011. Publicly listed companies are dominated by industrial (including telecommunication and services) and consumer goods companies. Large caps account for 85 percent of market capitalization, though they amount to only one third of the number of listed companies. There are currently 12 foreign companies listed in Japan. The number of new listed companies had decreased overtime but increased in 2011. In 2010, 26 new companies were listed in the TSE, while 68 delisted.

\begin{tabular}{|c|c|c|c|c|c|c|c|}
\hline & $\begin{array}{c}\text { Listed } \\
\text { companies }\end{array}$ & $\begin{array}{l}\text { Listed in } \\
\text { one } \\
\text { exchange }\end{array}$ & $\begin{array}{c}\text { Listed in } \\
\text { multiple } \\
\text { exchanges }\end{array}$ & $\begin{array}{l}\text { Five stock } \\
\text { exchanges }\end{array}$ & $\begin{array}{l}\text { Four stock } \\
\text { exchanges }\end{array}$ & $\begin{array}{l}\text { Three stock } \\
\text { exchanges }\end{array}$ & $\begin{array}{l}\text { Two stock } \\
\text { exchanges }\end{array}$ \\
\hline Tokyo & 2,280 & 1,552 & 728 & 24 & 12 & 81 & 611 \\
\hline Osaka & 1,745 & 1,188 & 557 & 24 & 12 & 78 & 443 \\
\hline Nagoya & 341 & 101 & 240 & 24 & 11 & 62 & 143 \\
\hline Fukuoka & 129 & 38 & 91 & 24 & 10 & 17 & 40 \\
\hline Sapporo & 76 & 21 & 55 & 24 & 3 & 5 & 23 \\
\hline Total & 3,647 & 2,900 & 747 & 24 & 12 & 81 & 630 \\
\hline
\end{tabular}

21. The TSE and the London Stock Exchange recently established a joint venture called Tokyo AIM, a new Tokyo equity based market for growing companies that is only open to professional investors. The market is still at an early stage. Tokyo AIM is also considering a debt securities market for professional investors only.

i) Note-The TSE plans to integrate TOKYO AIM into the Tokyo Stock Exchange effective July 1, 2012, and re-brand the TOKYO AIM market as 'TOKYO PRO Market.'

\section{Bond markets}

22. In recent years, Japanese companies have issued increasing amounts of corporate bonds, even though the size of this market remains small compared to other advanced economies. For 2010 , the total amount of bond issuance was $¥ 198,439$ billion, out of which only 4.8 percent were corporate bonds, municipal bonds amount to 3.9 percent, while Japanese government bonds (JGBs) make up for 83.6 percent. 
23. Trading of debt is mostly conducted in the over the counter (OTC) markets. Outside of OTC, the TSE is the main securities exchange in Japan, though the number of companies with listed debt is small compared to equities. No straight bonds are listed on the TSE, except for certain government debt bonds. Some convertible bonds are currently listed (as of November 30, 2010, the number of issuers was 37, the number of listed securities was 39 and the total amount was $¥ 1,239$ billion).

\section{Collective investment schemes}

24. As of end 2010 the total amount of assets under management (AUM) held by investment trusts amounted to $¥ 98$ trillion. Of this amount, $¥ 63$ trillion was invested in publicly offered investment trusts, roughly $¥ 4$ trillion in real estate investment trusts and $¥ 31$ trillion in privately placed investment trusts. Of the assets invested in publicly offered investment trusts, $¥ 52$ trillion were invested in stock investment trusts, $¥ 9$ trillion in bond investment trusts and $¥ 2$ trillion in MMF. The major securities firms, as well as most of the major banks, are the largest CIS managers.

\section{Securities intermediaries}

25. There are currently 322 Type I FIBOs operating in Japan, out of which 22 are foreign firms (not incorporated). The majority of them are small firms with simple business models, and still retail oriented. However, there are a few large firms with complex business models (e.g., including proprietary trading and derivatives portfolios). There are currently 16 securities companies subject to consolidated supervision. A subgroup of them is subject to more intense monitoring and supervision, based on an assessment of their business models and potential systemic implications. In their case supervision (off and onsite) is assigned to a dedicated unit, the OSBM. Currently 19 firms have presence overseas. The main overseas cities where they operate are New York, London, Singapore, and Hong Kong.

26. There are other intermediaries providing services in the market. In addition to Type I FIBOs, there are 1,293 Type II, 1,122 Investment Advisory and Agency Business and 322 IMBOs, as of November 2011.

\section{Trading platforms}

27. There are six exchanges operating in Japan-the TSE, the Osaka Stock Exchange (OSE), the Nagoya Stock Exchange, the Fukuoka Stock Exchange, the Sapporo Stock Exchange and the Tokyo AIM. However, only the TSE and the OSE have significant trading volumes. On the cash side, the TSE accounts for roughly 90 percent of trading volumes, while the OSE is the main market in connection with derivatives. A merger between these two exchanges has recently been agreed, with completion expected by 2013 . In addition, there are five PTS that trade equity, government debt, and corporate debt; but their trading volumes are not significant. 


\section{PRECONDITIONS FOR EFFECTIVE SECURITIES REGULATION}

28. Market participants highlighted the need to further strengthen corporate governance, through the inclusion of additional independent directors and the constitution of strong, independent bodies (such as a system of committees) to support

the oversight function of the board. All other preconditions appear to be largely in place. In particular, foreign issuers can tap the markets under similar conditions to domestic issuers. Foreign corporations can register as financial instruments business operators, with the same requirements than domestic corporations and there are no barriers for foreign investors to invest in the domestic market. The company law is modern and it is easy to constitute a corporation in Japan - incorporation typically takes less than a week. The insolvency framework includes rehabilitation procedures. Out of court proceedings can be worked out, and guidelines exist in this regard. The judiciary system is perceived as impartial. The prosecution office has created specialized offices in Tokyo, Japan, and Osaka, Japan, to deal with financial crime, but participants commented that courts might lack expertise. Accounting and auditing standards do not have major differences from international standards.

\section{MaIn FindingS}

29. Principles for the regulator: Responsibilities for the supervision of securities markets lies in the FSA, the SESC, and the CPAAOB. Certain features of the legal framework raise concerns in regard to their independence; however, in practice there is no evidence of day-to-day interference from the government. In the areas of their competencies, such agencies have been provided with broad powers vis-à-vis regulated entities, although the FSA cannot impose money penalties except in connection with a limited number of misconducts. The FSA has taken important steps to strengthen its capacity to identify and monitor emerging and systemic risk.

30. Principles for SROs: There are a number of SROs currently active and most have a long history of operation. They are subject to "authorization" and must meet criteria that address issues such as capacity, management of conflict of interest, fair treatment of members, and confidentiality. The FSA has enforcement powers over them. The FSA has developed a system of oversight tailored to each SRO that appears to be working well.

31. Principles for enforcement: Supervision of securities firms requires further strengthening. First, the FSA has not yet developed a framework to identify and determine the scale and scope of risks of individual firms and determine the intensity of regulatory intervention (including on-site inspections). In addition, the coverage of the on-site inspection program is limited, especially for smaller Type I and IMBOs as well as for Type II and investment advisors - most of which are inspected only by cause. In connection with enforcement, the assessors observed that the FSA is making more use of stronger measures, such as suspensions, in addition to orders for improvement on which it has traditionally 
relied. In such context, it is important that the FSA periodically reviews its strategy towards enforcement. Criminal convictions have been secured, but commuted sentences can limit the effect of deterrence.

32. Principles for issuers: Issuers of public offering are subject to disclosure obligations at the moment of registration and on a periodic and on-going basis that are in line with the IOSCO Principles. The FSA and the SESC have a system to review offering documents as well as periodic reports, which helps to ensure compliance by issuers with their disclosure obligations. Basic rights of shareholders are imbedded in company law. Certain additional protections are provided by the FIEA, in particular the requirement for a mandatory tender offer under certain conditions. There are notification obligations for substantial holdings. Holdings of insiders must be included in the disclosure documents but a system of timely notification of transactions carried out by them is not in place. Financial statements must be prepared according to local GAAPs, which are broadly consistent with IFRS.

\section{Principles for auditors, credit rating agencies and other information service} providers: A system of quality control for auditors is in place, which involves reviews by JICPA (the professional body) under the oversight of the CPAAOB. Such system is also complemented with direct examinations by the CPAAOB. Auditors are required to be independent of the entities they audit. Issuers' mechanisms to monitor auditors' independence require strengthening. Credit rating agencies are registered by the FSA, and are subject to ongoing supervision through reporting and on-site inspections. There is a framework in place for sell-side analysts to address conflicts of interest, which is based on disclosure.

34. Principles for collective investment schemes: Managers and distributors of CIS are required to register with the FSA. Registration requirements for managers (who must register as IMBOs) include capital requirements, fit and proper requirements and organizational requirements or deposits for operation. The SESC does not have a policy to inspect newly registered CIS managers within a short timeframe after registration. The current risk-based approach ensures regular on-site inspections for CIS managers, although the SESC should further strengthen the inspection program for CIS managers especially if the managed CIS is offered to the public and is subject to similar disclosure obligations to an issuer. Assets must be entrusted to a separate custodian. There is no obligation that the custodian be independent; however, custodians (trust banks) are subject to regulation and supervision by the FSA. Assets must be valued at fair value. ITAJ has developed guidance on valuation of assets, including illiquid assets. Conditions of suspensions of redemptions must be disclosed in the offering documents. Suspensions of redemptions are notified to the FSA.

35. Principles for securities intermediaries: Financial instruments business may only be carried on in Japan by entities registered by the FSA and that comply with registration requirements, which include minimum capital, fit and proper and organizational requirements. The SESC does not have a policy to inspect newly registered FIBOs within a 
short timeframe after registration. Ongoing capital requirements apply only to Type I FIBOs, which must comply and report a capital ratio similar to Basel II. Reporting requirements are extensive for Type I FIBOs. Smaller intermediaries are not necessarily subject to external audit. The current risk-based approach ensures regular inspection of larger Type I FIBOs and IMBOs by the FSA, which is complemented by JSDA/TSE inspections and ITAJ inspections. Longer cycles apply to smaller Type I and IMBOs, Type II and investment advisors are inspected mainly by cause. The FSA has not developed a plan to deal with the failure of a securities firm, but experiences of how past failures were handled have been documented.

36. Principles for secondary markets: Exchanges and PTS are the only secondary markets that can trade securities and each must comply with criteria set down by FSA. The SROs are responsible for ensuring orderly trading, while the SESC is responsible for market surveillance for purposes of detecting unfair trading practices - in such function, it is supported by the exchanges. There has been active enforcement of the requirements prohibiting unfair trading practices. CCPs manage exposures on a daily basis and have powers to request members to post additional margin. Default procedures are known to members. Price limits apply in both the cash and derivatives and circuit breakers apply to derivatives trading if there is excessive volatility. Naked short selling is prohibited. 
Table 1. Japan FSAP_Summary Implementation of the IOSCO Principles

\begin{tabular}{|c|c|c|}
\hline Principle & Grade & Findings \\
\hline $\begin{array}{l}\text { Principle } 1 \text {. The responsibilities of the Regulator } \\
\text { should be clear and objectively stated. }\end{array}$ & FI & $\begin{array}{l}\text { The mandate of the FSA, the SESC, and the } \\
\text { CPAAOB are established by law. A cabinet } \\
\text { ordinance defines the functions that are still retained } \\
\text { by the PM. From an operational perspective the } \\
\text { structure is complex as several functions are } \\
\text { delegated into the local finance bureaus. There do } \\
\text { not appear to be major gaps; however certain } \\
\text { functions are still retained by the PM. There do not } \\
\text { appear to problems with level playing field. } \\
\text { Mechanisms for cooperation in particular between } \\
\text { the FSA and the SESC have improved over time } \\
\text { fostered by informal arrangements such as rotation, } \\
\text { and more formal arrangements such as meetings at } \\
\text { senior level. }\end{array}$ \\
\hline $\begin{array}{l}\text { Principle } 2 \text {. The Regulator should be operationally } \\
\text { independent and accountable in the exercise of its } \\
\text { functions and powers. }\end{array}$ & BI & $\begin{array}{l}\text { Certain features of the legal framework might pose a } \\
\text { risk to the independence of the FSA (including the } \\
\text { SESC and CPAAOB), in particular (i) the legal } \\
\text { nature of the FSA and the fact that the scope of its } \\
\text { functions is defined by cabinet order, rather than by } \\
\text { law; (ii) the fact that its budget can (and has) been } \\
\text { adjusted by the MoF; and (iii) the involvement in } \\
\text { important matters of the MoFS. However, there is no } \\
\text { evidence of interference in day-to-day functions by } \\
\text { the MoFS. By practice there is a "term limit" for the } \\
\text { Commissioner as he/she steps down every two to } \\
\text { three years and, at the same time, there is a strong } \\
\text { framework of accountability vis-à-vis the } \\
\text { Government and the public. The FSA and the SESC } \\
\text { prepare annual reports, and the accounts of the FSA } \\
\text { have to be audited by the Audit Board of Japan. }\end{array}$ \\
\hline $\begin{array}{l}\text { Principle } 3 \text {. The Regulator should have adequate } \\
\text { powers, proper resources and the capacity to perform } \\
\text { its functions and exercise its powers. }\end{array}$ & PI & $\begin{array}{l}\text { The civil service system poses challenges to the } \\
\text { retention of experts. The level of resources allocated } \\
\text { to securities markets might be affecting the coverage } \\
\text { of the inspection program and can have an impact on } \\
\text { the overall effectiveness of enforcement. The FSA } \\
\text { conducts strategic planning and has basic } \\
\text { mechanisms to ensure that functions are adequately } \\
\text { discharged. The FSA is active on promoting investor } \\
\text { education. }\end{array}$ \\
\hline
\end{tabular}




\begin{tabular}{|c|c|c|}
\hline $\begin{array}{l}\text { Principle } 4 \text {. The Regulator should adopt clear and } \\
\text { consistent regulatory processes. }\end{array}$ & FI & $\begin{array}{l}\text { The FSA has adopted a public consultation process } \\
\text { for the development of regulations. Requirements for } \\
\text { registration are established by Law and Cabinet } \\
\text { Ordinance, and are published on the website. A } \\
\text { broad set of information including supervisory and } \\
\text { enforcement policies and annual reports are also } \\
\text { available in the website. Recommendations on } \\
\text { enforcement and sanctions imposed (except those } \\
\text { related to financial soundness) are public. } \\
\text { Individuals can seek redress in the judicial tribunals } \\
\text { against acts of the FSA. In the cases of denial of a } \\
\text { license, cancellation of a license, or the imposition } \\
\text { of enforcement actions, a due process has to be } \\
\text { followed. }\end{array}$ \\
\hline $\begin{array}{l}\text { Principle } 5 \text {. The staff of the Regulator should observe } \\
\text { the highest professional standards, including } \\
\text { appropriate standards of confidentiality. }\end{array}$ & FI & $\begin{array}{l}\text { The FSA staff is subject to the duties of loyalty, } \\
\text { fairness and confidentiality. The FSA has issued } \\
\text { detailed guidance in connection with securities } \\
\text { transactions. An internal office monitors compliance } \\
\text { with such obligations. In the past, administrative } \\
\text { actions have been imposed on staff who have } \\
\text { violated such obligations. Cooling off periods exist. }\end{array}$ \\
\hline $\begin{array}{l}\text { Principle } 6 \text {. The Regulator should have or contribute } \\
\text { to a process to monitor, mitigate and manage } \\
\text { systemic risk, appropriate to its mandate. }\end{array}$ & BI & $\begin{array}{l}\text { The FSA has created two offices to be able to better } \\
\text { monitor systemic risk: the Office of Market Analysis } \\
\text { and the Office of Securities Business Monitoring. In } \\
\text { particular the latter engages in active monitoring of } \\
\text { large complex firms. A framework to more } \\
\text { comprehensively and systematically identify } \\
\text { systemic risk is needed. Continuation of cooperation } \\
\text { between the FSA and the BOJ in the context of crisis } \\
\text { management and resolution of weak firms is } \\
\text { encouraged. }\end{array}$ \\
\hline $\begin{array}{l}\text { Principle } 7 . \text { The Regulator should have or contribute } \\
\text { to a process to review the perimeter of regulation } \\
\text { regularly. }\end{array}$ & BI & $\begin{array}{l}\text { The FSA has not singled out a specific office to deal } \\
\text { with emerging risks and review of the perimeter of } \\
\text { regulation. However the offices mentioned in } \\
\text { Principle } 6 \text { contribute to such function, as well as the } \\
\text { off and on-site monitoring of FIBOs, CIS, and } \\
\text { market infrastructure. Other informal mechanisms } \\
\text { such as meetings of senior officials help to identify } \\
\text { sources of risk. Usually, on an annual basis, the FSA } \\
\text { makes proposals to the Diet for changes to the FIEA } \\
\text { to address weaknesses identified through all the } \\
\text { mechanisms described above. A framework to more } \\
\text { comprehensively and systematically identify } \\
\text { emerging risks is needed. }\end{array}$ \\
\hline
\end{tabular}




\begin{tabular}{|c|c|c|}
\hline $\begin{array}{l}\text { Principle } 8 \text {. The Regulator should seek to ensure that } \\
\text { conflicts of interest and misalignment of incentives } \\
\text { are avoided, eliminated, disclosed or otherwise } \\
\text { managed. }\end{array}$ & FI & $\begin{array}{l}\text { The legal and regulatory framework in place requires } \\
\text { regulated entities (FIBOs, IMBOs, auditors, and sell } \\
\text { side analysts) to establish policies, procedures, and } \\
\text { internal controls to properly address conflict of } \\
\text { interest. Such obligations are monitored via onsite } \\
\text { inspections. Issuers are required to provide } \\
\text { disclosure to the market, which is monitored via the } \\
\text { system of review of periodic information. In } \\
\text { particular, in connection with structured products, } \\
\text { the FSA introduced changes to its regulatory } \\
\text { framework to address potential misalignment of } \\
\text { incentives. }\end{array}$ \\
\hline $\begin{array}{l}\text { Principle } 9 . \text { Where the regulatory system makes use } \\
\text { of SROs that exercise some direct oversight } \\
\text { responsibility for their respective areas of } \\
\text { competence, such SROs should be subject to the } \\
\text { oversight of the Regulator and should observe } \\
\text { standards of fairness and confidentiality when } \\
\text { exercising powers and delegated responsibilities. }\end{array}$ & FI & $\begin{array}{l}\text { Several entities perform self-regulatory functions, } \\
\text { including the JSDA, the ITAJ, the TSE SRO and the } \\
\text { exchanges. They all require "approval" based on } \\
\text { requirements concerning their capacity to operate, } \\
\text { their rules, the management of conflicts of interest } \\
\text { and confidential information. The FSA has } \\
\text { appropriate powers to oversee the SROs. All of the } \\
\text { SROs are subject to reporting obligations tailored to } \\
\text { their functions. Frequent onsite inspections of } \\
\text { TSE/OSE are carried out but less so for ITAJ/JSDA. } \\
\text { On-site inspections are complemented by regular } \\
\text { communication such as calls and periodic meetings } \\
\text { at different levels of the organizations. }\end{array}$ \\
\hline $\begin{array}{l}\text { Principle } 10 \text {. The Regulator should have } \\
\text { comprehensive inspection, investigation and } \\
\text { surveillance powers. }\end{array}$ & FI & $\begin{array}{l}\text { The FSA has comprehensive powers to request } \\
\text { reports and conduct inspections on regulated entities. }\end{array}$ \\
\hline $\begin{array}{l}\text { Principle } 11 \text {. The Regulator should have } \\
\text { comprehensive enforcement powers. }\end{array}$ & BI & $\begin{array}{l}\text { The FSA has been given the power to impose } \\
\text { enforcement actions on regulated entities including } \\
\text { orders for improvement, suspensions for not more } \\
\text { than six months and cancellations of registrations. It } \\
\text { can also seek the imposition of cease and desist } \\
\text { orders from a district court on any person who has } \\
\text { violated the FIEA. Administrative penalties, } \\
\text { however, can only be imposed for limited categories } \\
\text { of misconduct. In addition, in some cases the level of } \\
\text { penalties is low and therefore casts doubts on their } \\
\text { deterrent effects. }\end{array}$ \\
\hline
\end{tabular}




\begin{tabular}{|c|c|c|}
\hline $\begin{array}{l}\text { Principle } 12 \text {. The regulatory system should ensure an } \\
\text { effective and credible use of inspection, investigation, } \\
\text { surveillance and enforcement powers and } \\
\text { implementation of an effective compliance program. }\end{array}$ & PI & $\begin{array}{l}\text { The coverage of the inspection program (including } \\
\text { inspections by the JSDA and ITAJ) is robust for } \\
\text { larger Type I FIBOs and IMBOs. The coverage for } \\
\text { smaller Type I and IMBOs is more limited, and } \\
\text { Type II and Investment Advisors are inspected } \\
\text { mainly by cause. The SESC does not make } \\
\text { substantive use of horizontal reviews, nor random } \\
\text { inspections, and there are no inspections associated } \\
\text { with the registration process. As a result small firms } \\
\text { might go uninspected for long periods of time, which } \\
\text { could pose risks to investor protection. The FSA } \\
\text { seeks to balance such risk via off-site monitoring, } \\
\text { mainly through annual reporting, and other ad-hoc } \\
\text { reporting obligations (notifications). However, the } \\
\text { findings from the inspections carried out by the } \\
\text { SESC show that material problems are found in this } \\
\text { segment of small firms. The FSA is showing more } \\
\text { use of stronger measures such as suspensions, in } \\
\text { addition to the "traditional" orders for improvement. } \\
\text { Enforcement in connection with unfair trading } \\
\text { practices appears to be active, as money penalties } \\
\text { have been imposed. Criminal convictions have been } \\
\text { secured, but commuted sentences are common. }\end{array}$ \\
\hline $\begin{array}{l}\text { Principle } 13 \text {. The Regulator should have authority to } \\
\text { share both public and non-public information with } \\
\text { domestic and foreign counterparts. }\end{array}$ & FI & $\begin{array}{l}\text { The FSA is empowered by law to share public and } \\
\text { non-public information with domestic and foreign } \\
\text { regulators. Domestic regulators must have } \\
\text { equivalent confidentiality obligations to the FSA. } \\
\text { Foreign regulators must be able to share information } \\
\text { with the FSA. The information can only be used for } \\
\text { regulatory purposes although for criminal trials a } \\
\text { special procedure can be used to enable release. Staff } \\
\text { is bound by law to observe confidentiality. }\end{array}$ \\
\hline $\begin{array}{l}\text { Principle 14. Regulators should establish information } \\
\text { sharing mechanisms that set out when and how they } \\
\text { will share both public and non-public information } \\
\text { with their domestic and foreign counterparts. }\end{array}$ & FI & $\begin{array}{l}\text { Informal arrangements to share information apply } \\
\text { domestically particularly with the BOJ, and intensive } \\
\text { cooperation takes place in connection with large } \\
\text { complex securities firms. By law the FSA can share } \\
\text { information with overseas regulators and is a } \\
\text { signatory to the IOSCO MMoU. Bilateral } \\
\text { arrangements (by way of exchange of letters) to } \\
\text { share information have been signed with numerous } \\
\text { overseas regulators. Special arrangements for a } \\
\text { supervisory college for one large regulated entity are } \\
\text { operating. }\end{array}$ \\
\hline $\begin{array}{l}\text { Principle } 15 \text {. The regulatory system should allow for } \\
\text { assistance to be provided to foreign Regulators who } \\
\text { need to make inquiries in the discharge of their } \\
\text { functions and exercise of their powers. }\end{array}$ & FI & $\begin{array}{l}\text { FSA regularly assists foreign regulators in obtaining } \\
\text { information for regulatory purposes. Under the } \\
\text { IOSCO MMoU no request for assistance has been } \\
\text { refused. }\end{array}$ \\
\hline
\end{tabular}




\begin{tabular}{|c|c|c|}
\hline $\begin{array}{l}\text { Principle } 16 . \text { There should be full, accurate and } \\
\text { timely disclosure of financial results, risk and other } \\
\text { information that is material to investors' decisions. }\end{array}$ & BI & $\begin{array}{l}\text { Issuers of public offerings must submit a registration } \\
\text { statement to the FSA. They are also required to } \\
\text { submit periodic reports on a semi-annual or quarterly } \\
\text { basis (the latter if they are also listed). They must } \\
\text { report material events. The FSA reviews all } \\
\text { registration statements, and has developed } \\
\text { mechanisms to review periodic reports, which } \\
\text { include both off-site reviews as well as on-site } \\
\text { inspections. However, municipal bonds that are } \\
\text { offered to the public are not subject to such } \\
\text { disclosure obligations. }\end{array}$ \\
\hline $\begin{array}{l}\text { Principle } 17 \text {. Holders of securities in a company } \\
\text { should be treated in a fair and equitable manner. }\end{array}$ & BI & $\begin{array}{l}\text { The Company Act provides a general framework for } \\
\text { shareholders' rights. A mandatory tender offer must } \\
\text { be launched if after the acquisition the offeror would } \\
\text { acquire more than one-third (five in certain } \\
\text { situations) of the securities of a listed company. } \\
\text { Substantial holdings must be disclosed, as well as } \\
\text { changes in holdings. Insiders' holdings must be } \\
\text { disclosed in the disclosure documents (registration } \\
\text { statement, annual and semiannual or quarterly } \\
\text { report), but there is no system of timely notification } \\
\text { of their transactions. }\end{array}$ \\
\hline $\begin{array}{l}\text { Principle } 18 \text {. Accounting standards used by issuers to } \\
\text { prepare financial statements should be of a high and } \\
\text { internationally acceptable quality. }\end{array}$ & FI & $\begin{array}{l}\text { Annual financial statements of issuers of public } \\
\text { offerings must be audited according to local GAAPs. } \\
\text { There are currently no material differences between } \\
\text { Japanese GAAPs and IFRS. The FSA has developed } \\
\text { mechanisms that seek to ensure compliance by } \\
\text { issuers with accounting standards, including } \\
\text { mandatory audit as well as its own program of off- } \\
\text { site and on-site monitoring of periodic information } \\
\text { submitted by issuers. }\end{array}$ \\
\hline $\begin{array}{l}\text { Principle } 19 \text {. Auditors should be subject to adequate } \\
\text { levels of oversight. }\end{array}$ & FI & $\begin{array}{l}\text { There are qualifications for auditors. JICPA } \\
\text { undertakes quality control reviews of auditors on a } \\
\text { three year cycle (every two years for the four largest } \\
\text { firms). Auditors that do not satisfy the quality } \\
\text { control are included in an unsatisfactory list and } \\
\text { cannot conduct audits of listed companies. The } \\
\text { CPAAOB oversees the work carried out by JICPA, } \\
\text { and undertakes its own inspections of auditors. The } \\
\text { FSA has the power to impose regulatory measures } \\
\text { on JICPA as well as on auditors. }\end{array}$ \\
\hline $\begin{array}{l}\text { Principle } 20 \text {. Auditors should be independent of the } \\
\text { issuing entity that they audit. }\end{array}$ & BI & $\begin{array}{l}\text { Independence of external auditors is required by law. } \\
\text { Non audit services are restricted. Rotation every } \\
\text { seven years (and cooling off for two years) of the } \\
\text { lead engagement team for large and listed companies } \\
\text { is required by law. Five year rotation (and five years } \\
\text { cooling off) applies where an audit firm has } 100 \text { or } \\
\text { more listed company clients. Governance } \\
\text { arrangements to monitor auditors' independence } \\
\text { require strengthening. }\end{array}$ \\
\hline
\end{tabular}




\begin{tabular}{|c|c|c|}
\hline $\begin{array}{l}\text { Principle } 21 \text {. Audit standards should be of a high and } \\
\text { internationally acceptable quality. }\end{array}$ & FI & $\begin{array}{l}\text { Financial statements in public offering and listing } \\
\text { documents must be prepared based on local auditing } \\
\text { standards. These are the auditing standards set by the } \\
\text { BAC (advisory body within the FSA) supplemented } \\
\text { by JICPA's Implementation guidelines (both not } \\
\text { finalized until after public comments considered). } \\
\text { There are no material differences between local } \\
\text { standards and IAS. }\end{array}$ \\
\hline $\begin{array}{l}\text { Principle } 22 \text {. Credit rating agencies should be subject } \\
\text { to adequate levels of oversight. The regulatory system } \\
\text { should ensure that credit rating agencies whose } \\
\text { ratings are used for regulatory purposes are subject to } \\
\text { registration and ongoing supervision. }\end{array}$ & FI & $\begin{array}{l}\text { CRAs whose ratings are to be used for regulatory } \\
\text { purposes require recognition by the FSA as an } \\
\text { external credit assessment institution (ECAI). } \\
\text { Recognition criteria are in line with the IOSCO } \\
\text { Principles. There is a separate registration process } \\
\text { under the FIEA for any CRA, whether its ratings are } \\
\text { to be used for regulatory purposes or not. } \\
\text { Registration requirements are in line with the } \\
\text { IOSCO principles. In practice, all CRAs used for } \\
\text { regulatory purposes have registered with the FSA } \\
\text { under the FIEA. The FSA subjects them to periodic } \\
\text { reporting and the SESC carries out inspections on } \\
\text { them. }\end{array}$ \\
\hline $\begin{array}{l}\text { Principle } 23 \text {. Other entities that offer investors } \\
\text { analytical or evaluative services should be subject to } \\
\text { oversight and regulation appropriate to the impact } \\
\text { their activities have on the market or the degree to } \\
\text { which the regulatory system relies on them. }\end{array}$ & FI & $\begin{array}{l}\text { The JSDA has developed a specific framework in } \\
\text { connection with sell-side analysts, which is based on } \\
\text { disclosure in the corresponding research of potential } \\
\text { conflict of interests. }\end{array}$ \\
\hline $\begin{array}{l}\text { Principle } 24 \text {. The regulatory system should set } \\
\text { standards for the eligibility, governance, organization } \\
\text { and operational conduct of those who wish to market } \\
\text { or operate a collective investment scheme. }\end{array}$ & BI & $\begin{array}{l}\text { CIS managers must register as IMBOs with the FSA } \\
\text { and distributors of CIS must register as FIBOs. } \\
\text { Requirements are described under Principle 29. The } \\
\text { FSA does not have the policy to inspect newly } \\
\text { registered CIS managers within a short timeframe } \\
\text { after registration. IMBOs that manage CIS are } \\
\text { subject to periodic inspections, although the } \\
\text { supervisory approach should be strengthened. }\end{array}$ \\
\hline $\begin{array}{l}\text { Principle } 25 \text {. The regulatory system should provide } \\
\text { for rules governing the legal form and structure of } \\
\text { collective investment schemes and the segregation } \\
\text { and protection of client assets. }\end{array}$ & BI & $\begin{array}{l}\text { The ITIC authorizes two legal forms for CIS: trust } \\
\text { and corporations. For CIS of public offering } \\
\text { registration documents as well as the prospectus } \\
\text { must include detailed information on the legal form } \\
\text { and rights of investors. The ITIC requires that assets } \\
\text { be entrusted to a separate custodian-usually a trust } \\
\text { bank. There is no requirement that the custodian be } \\
\text { of a different group, although general obligations for } \\
\text { appropriate management of conflict of interest apply } \\
\text { and custodians (trust banks) are subject to } \\
\text { supervision by the FSA. Resolution of CIS requires } \\
\text { investors' approval. }\end{array}$ \\
\hline
\end{tabular}




\begin{tabular}{|c|c|c|}
\hline $\begin{array}{l}\text { Principle } 26 \text {. Regulation should require disclosure, as } \\
\text { set forth under the principles for issuers, which is } \\
\text { necessary to evaluate the suitability of a collective } \\
\text { investment scheme for a particular investor and the } \\
\text { value of the investor's interest in the scheme. }\end{array}$ & FI & $\begin{array}{l}\text { CIS of public offering must submit an "offering" } \\
\text { document to the FSA for registration. The local } \\
\text { finance bureaus conduct review of the registration } \\
\text { documents. ITAJ has developed detailed rules } \\
\text { concerning the content of the prospectus which are } \\
\text { aimed to ensure the comparability of information } \\
\text { available to investors. Material changes have to be } \\
\text { approved by investors. }\end{array}$ \\
\hline $\begin{array}{l}\text { Principle } 27 \text {. Regulation should ensure that there is a } \\
\text { proper and disclosed basis for asset valuation and the } \\
\text { pricing and the redemption of units in a collective } \\
\text { investment scheme. }\end{array}$ & FI & $\begin{array}{l}\text { The FIEA requires fair valuation. ITAJ regulations } \\
\text { require mark-to-market (MTM) valuation for liquid } \\
\text { assets and independent valuation for illiquid assets. } \\
\text { Net asset value (NAV) has to be calculated on a } \\
\text { daily basis, and subscription and redemption prices } \\
\text { have to be available to investors in the website of } \\
\text { ITAJ. Pursuant to regulations from ITAJ pricing } \\
\text { errors must be covered by the IMBO. Suspensions of } \\
\text { redemptions are notified immediately to the FSA } \\
\text { which would have the power to ask for additional } \\
\text { information and ask for lifting of suspension. }\end{array}$ \\
\hline $\begin{array}{l}\text { Principle 28. Regulation should ensure that hedge } \\
\text { funds and/or hedge funds managers/advisers are } \\
\text { subject to appropriate oversight. }\end{array}$ & FI & $\begin{array}{l}\text { The FIEA requires registration as an IMBO of any } \\
\text { entity who manages CIS regardless of their nature. } \\
\text { As a result, managers of hedge funds (HFs) must } \\
\text { register with the FSA. Registration requirements are } \\
\text { the same as for any other FIBO. Currently the FSA } \\
\text { does not require specific information on the HFs } \\
\text { themselves beyond the annual fund monitoring; } \\
\text { however it would have the powers to do so } \\
\text { according to the FIEA as well as to share this } \\
\text { information with other regulators in the same } \\
\text { conditions described in Principle } 13 \text {. }\end{array}$ \\
\hline $\begin{array}{l}\text { Principle } 29 \text {. Regulation should provide for minimum } \\
\text { entry standards for market intermediaries. }\end{array}$ & BI & $\begin{array}{l}\text { Only firms registered as a FIBO with the FSA can } \\
\text { conduct financial instruments business. Minimum } \\
\text { entry requirements apply including minimum } \\
\text { capital/deposits, "fit and proper" officers, adequate } \\
\text { internal controls and risk management and } \\
\text { sufficiency of resources. Registration is done by the } \\
\text { local Finance Bureau in accordance with FIEA and } \\
\text { FSA guidelines. The SESC does not have the policy } \\
\text { to conduct on-site inspections on newly registered } \\
\text { FIBOs within a short time frame after registration. }\end{array}$ \\
\hline
\end{tabular}




\begin{tabular}{|c|c|c|}
\hline $\begin{array}{l}\text { Principle } 30 \text {. There should be initial and ongoing } \\
\text { capital and other prudential requirements for market } \\
\text { intermediaries that reflect the risks that the } \\
\text { intermediaries undertake. }\end{array}$ & PI & $\begin{array}{l}\text { Initial minimum net assets or deposits for operations } \\
\text { apply to FIBOs. On an ongoing basis only Type I } \\
\text { must maintain a capital ratio formula (similar to } \\
\text { Basel II) with monthly/quarterly/annual reporting to } \\
\text { the FSA. Other FIBOs are only required to maintain } \\
\text { the minimum capital at registration, and submit an } \\
\text { annual business report, which includes financial } \\
\text { statements. External audit of financial statements is } \\
\text { only required for large companies. Type I FIBOs are } \\
\text { required to submit a report from an external auditor } \\
\text { on segregation of assets of clients to the JSDA. }\end{array}$ \\
\hline $\begin{array}{l}\text { Principle } 31 \text {. Market intermediaries should be } \\
\text { required to establish an internal function that delivers } \\
\text { compliance with standards for internal organization } \\
\text { and operational conduct, with the aim of protecting } \\
\text { the interests of clients and their assets and ensuring } \\
\text { proper management of risk, through which } \\
\text { management of the intermediary accepts primary } \\
\text { responsibility for these matters. }\end{array}$ & PI & $\begin{array}{l}\text { By law, a FIBO must have internal controls, legal } \\
\text { and compliance functions (independent from sales or } \\
\text { asset management) and risk management } \\
\text { procedures. However, in practice the independence } \\
\text { of such functions requires strengthening in particular } \\
\text { in smaller firms. FIBOs have information obligations } \\
\text { vis-à-vis clients, and suitability requirements apply. } \\
\text { Clients' assets must be segregated and Type I FIBOs } \\
\text { must have this control externally audited on an } \\
\text { annual basis. On-site inspections are concentrated in } \\
\text { the larger Type I FIBOs and IMBOs. The coverage } \\
\text { for smaller Type I and IMBOs is limited, and Type } \\
\text { II FIBOs and Investment Advisors are inspected } \\
\text { mainly by cause. The SESC does not make } \\
\text { substantive use of horizontal reviews, nor random } \\
\text { inspections. }\end{array}$ \\
\hline $\begin{array}{l}\text { Principle } 32 \text {. There should be procedures for dealing } \\
\text { with the failure of a market intermediary in order to } \\
\text { minimize damage and loss to investors and to contain } \\
\text { systemic risk. }\end{array}$ & BI & $\begin{array}{l}\text { Early warning applies for Type I FIBOs, along with } \\
\text { prompt corrective action. Large complex securities } \\
\text { firms are under closer monitoring through the } \\
\text { OSBM. Resolution of securities firms is governed by } \\
\text { the general regime for corporations, including for } \\
\text { large complex firms. Under rehabilitation procedures } \\
\text { the FSA can request the appointment of an } \\
\text { administrator. The FSA has not developed a general } \\
\text { procedure manual to deal with the insolvency of a } \\
\text { large complex firm, but experience of dealing with } \\
\text { previous (significant) failures has been fully } \\
\text { documented by FSA, which is functioning as a } \\
\text { guiding document. Stress testing by CCPs has been } \\
\text { undertaken at FSA request. }\end{array}$ \\
\hline $\begin{array}{l}\text { Principle } 33 \text {. The establishment of trading systems } \\
\text { including securities exchanges should be subject to } \\
\text { regulatory authorization and oversight. }\end{array}$ & FI & $\begin{array}{l}\text { Exchanges and PTS require minimum capital, } \\
\text { appropriate technology systems and their rules must } \\
\text { be vetted before approval. PTS can only be } \\
\text { established by Type I FIBOs and require an } \\
\text { independent expert IT report. }\end{array}$ \\
\hline
\end{tabular}




\begin{tabular}{|c|c|c|}
\hline $\begin{array}{l}\text { Principle } 34 \text {. There should be ongoing regulatory } \\
\text { supervision of exchanges and trading systems which } \\
\text { should aim to ensure that the integrity of trading is } \\
\text { maintained through fair and equitable rules that strike } \\
\text { an appropriate balance between the demands of } \\
\text { different market participants. }\end{array}$ & FI & $\begin{array}{l}\text { The SESC, exchanges, and the FIBOs in their } \\
\text { condition of operators of PTS conduct market } \\
\text { surveillance. The FSA authorizes changes to rules } \\
\text { and maintains close supervision of operations by } \\
\text { way of reports, ongoing dialogue and inspections. } \\
\text { PTS provide monthly and annual reports to the FSA, } \\
\text { as well as on an ad-hoc basis if they detect evidence } \\
\text { of market manipulation. }\end{array}$ \\
\hline $\begin{array}{l}\text { Principle } 35 \text {. Regulation should promote transparency } \\
\text { of trading. }\end{array}$ & FI & $\begin{array}{l}\text { Bids, offers, and trade information are made publicly } \\
\text { available for exchanges ( } 95 \text { percent of all trading) } \\
\text { and PTS. Electronic platforms for dark pools do not } \\
\text { appear to be a cause of concern. Internalization and } \\
\text { block trades are permitted and must be reported to } \\
\text { exchanges. }\end{array}$ \\
\hline $\begin{array}{l}\text { Principle } 36 \text {. Regulation should be designed to detect } \\
\text { and deter manipulation and other unfair trading } \\
\text { practices. }\end{array}$ & FI & $\begin{array}{l}\text { Administrative and criminal penalties apply for } \\
\text { unfair trading practices, including market } \\
\text { manipulation, false rumors and insider dealing. } \\
\text { There is active market surveillance by the SESC and } \\
\text { the exchanges. Administrative penalties have been } \\
\text { imposed and criminal convictions have been } \\
\text { secured. }\end{array}$ \\
\hline $\begin{array}{l}\text { Principle } 37 \text {. Regulation should aim to ensure the } \\
\text { proper management of large exposures, default risk } \\
\text { and market disruption. }\end{array}$ & FI & $\begin{array}{l}\text { Exposures of the larger complex firms are under } \\
\text { intense monitoring by the OSBM. The CCPs } \\
\text { monitor clearing members' positions on a daily } \\
\text { basis. If a participant's exposure becomes a concern, } \\
\text { the CCP has the power to request additional } \\
\text { collateral. Further transactions will be prohibited and } \\
\text { outstanding positions will closed out if this does not } \\
\text { occur. There are clear procedures in the event of } \\
\text { default which are available to members. Price limits } \\
\text { apply to both the cash and derivatives and circuit } \\
\text { breakers apply to derivatives trading if there is } \\
\text { excessive volatility. Naked short selling is } \\
\text { prohibited. }\end{array}$ \\
\hline $\begin{array}{l}\text { Principle } 38 \text {. Securities settlement systems and } \\
\text { central counterparties should be subject to regulatory } \\
\text { and supervisory requirements that are designed to } \\
\text { ensure that they are fair, effective and efficient and } \\
\text { that they reduce systemic risk. }\end{array}$ & N/A & \\
\hline \multicolumn{3}{|c|}{$\begin{array}{l}\text { Fully Implemented (FI), Broadly Implemented (BI), Partly Implemented (PI), Not Implemented (NI), Not } \\
\text { Applicable (NA) }\end{array}$} \\
\hline
\end{tabular}




\section{Table 2. Japan FSAP-Recommended Action Plan to Improve Implementation of the IOSCO Principles}

\begin{tabular}{|c|c|}
\hline Principle & Recommended Action \\
\hline Principle 1 & $\begin{array}{l}\text { The FSA and the SESC are encouraged to continue exploring } \\
\text { mechanisms to strengthen cooperation at the operational level and work } \\
\text { towards seamless functioning of off-site monitoring and on-site } \\
\text { inspections. }\end{array}$ \\
\hline Principle 2 & $\begin{array}{l}\text { The authorities should strengthen the independence of the FSA by such } \\
\text { initiatives as: (i) assigning all functions related to securities markets to } \\
\text { it via law; and (ii) exploring mechanisms to secure sufficient funding. } \\
\text { In addition, vis-à-vis accountability the authorities should assess the } \\
\text { benefits of formalizing the current practice of term limits for the } \\
\text { Commissioner. }\end{array}$ \\
\hline Principle 3 & $\begin{array}{l}\text { 1) The authorities should explore mechanisms to ensure that the } \\
\text { organization can retain sufficient experts across the organization, } \\
\text { including by reviewing salary conditions. } \\
\text { 2) The FSA should review resources allocated to securities markets, } \\
\text { in particular to on-site inspections. } \\
\text { 3) The FSA is encouraged to continue strengthening internal control } \\
\text { mechanisms to ensure that functions are adequately discharged. }\end{array}$ \\
\hline Principles 6 and 7 & $\begin{array}{l}\text { The FSA should consider developing arrangements that allow it to } \\
\text { more systematically identify, prioritize and determine the scale and } \\
\text { scope of risks coming from different entities/activities/products of the } \\
\text { financial markets that could serve as the basis for determining whether } \\
\text { and what type of regulatory intervention is needed. }\end{array}$ \\
\hline Principle 11 & $\begin{array}{l}\text { The authorities should consider reviewing the administrative money } \\
\text { penalty system to (i) ensure that the amount of the penalties provide a } \\
\text { deterrent effect and (ii) to expand its coverage to any violation of the } \\
\text { FIEA or the ITIC. }\end{array}$ \\
\hline Principle 12 & $\begin{array}{l}\text { 1) The FSA and SESC should consider complementing the current } \\
\text { system of expert judgment with a framework that allows them to } \\
\text { better determine the risks posed by individual firms, which could } \\
\text { serve as an input to determine the intensity of regulatory } \\
\text { intervention, including on-site inspections. } \\
\text { 2) The SESC should review and expand the coverage of the } \\
\text { inspection program in particular for smaller firms, Type II and } \\
\text { investment advisors (e.g., through more institution based } \\
\text { inspections, more use of horizontal reviews, and/or more use of } \\
\text { random inspections). } \\
\text { 3) The FSA should consider periodically reviewing the strategy } \\
\text { towards enforcement to ensure proper balance between different } \\
\text { types of measures. }\end{array}$ \\
\hline Principle 16 & $\begin{array}{l}\text { A legal reform should be pursued to subject municipal bonds that are } \\
\text { offered to the public to the disclosure regime set forth in the FIEA. } \\
\text { Alternatively more clarity as to the existence of a government } \\
\text { guarantee is encouraged. }\end{array}$ \\
\hline
\end{tabular}




\begin{tabular}{|c|c|}
\hline Principle & Recommended Action \\
\hline Principle 17 & $\begin{array}{l}\text { 1) A legal reform should be pursued to require "insiders" to notify to } \\
\text { the FSA and disclose to the public transactions made, in addition to } \\
\text { the current mechanism of disclosure through periodic reports. } \\
\text { 2) The FSA should consider extending tender offer provisions to on } \\
\text { the market transactions. }\end{array}$ \\
\hline Principle 19 & $\begin{array}{l}\text { 1) The CPAAOB should continue to keep under review the } \\
\text { sufficiency of JICPA's resources. } \\
\text { 2) Ensuring robust enforcement should also be continuously } \\
\text { monitored. }\end{array}$ \\
\hline Principle 20 & $\begin{array}{l}\text { The authorities should explore mechanisms to strengthen issuers' } \\
\text { governance arrangements for the selection of auditors, and monitoring } \\
\text { of auditors' independence, by for example requiring special reports } \\
\text { from auditors on their actions to ensure independence and requiring an } \\
\text { independent body of the issuer to review such reports, and follow up } \\
\text { with auditing firms when necessary. }\end{array}$ \\
\hline Principle 24 & $\begin{array}{l}\text { Refer to the recommended actions of Principle } 12 \text { (1) (2) and Principle } \\
29 .\end{array}$ \\
\hline Principle 25 & $\begin{array}{l}\text { The FSA should consider the imposition of additional safeguards in } \\
\text { connection with custody carried out by entities of the same group. }\end{array}$ \\
\hline Principle 29 & $\begin{array}{l}\text { The FSA/SESC should consider enhancing the registration process for } \\
\text { FIBOs for example, by including a policy of on-site inspection of } \\
\text { newly registered entities }\end{array}$ \\
\hline Principle 30 & $\begin{array}{l}\text { 1) The FSA should consider more frequent reporting for FIBOs other } \\
\text { than Type I in connection with their capital position and activities. } \\
\text { 2) The FSA should expand external auditing requirements to all } \\
\text { securities firms that hold clients assets. }\end{array}$ \\
\hline Principle 31 & $\begin{array}{l}\text { 1) The authorities should consider strengthening the requirements for } \\
\text { "independence" of the internal control and audit functions in } \\
\text { securities intermediaries, especially the smaller ones. } \\
\text { 2) Refer to the recommended actions of Principle } 12 \text { (2). }\end{array}$ \\
\hline Principle 32 & $\begin{array}{l}\text { 1) The authorities should document a contingency plan to be followed } \\
\text { in the event of an intermediary's failure. The plan should include } \\
\text { the type of regulatory actions necessary to protect investors from } \\
\text { loss and manage the situation. } \\
\text { 2) The authorities should continue discussing with other domestic } \\
\text { authorities, such as the BOJ, how to cooperate in the case of } \\
\text { financial crisis management, including the management of weak } \\
\text { financial institutions. In such context the authorities could consider } \\
\text { to elaborate contingency plans further. In addition, the authorities } \\
\text { are encouraged to develop a resolution plan for large complex } \\
\text { securities firms. }\end{array}$ \\
\hline Principle 33 & $\begin{array}{l}\text { The authorities should consider including as part of the licensing } \\
\text { criteria for exchanges a detailed IT systems assessment on the } \\
\text { robustness of the systems, either by internal expert staff or by an } \\
\text { independent external expert with the appropriate knowledge and } \\
\text { experience on exchange electronic trading systems. }\end{array}$ \\
\hline Principle 35 & $\begin{array}{l}\text { The FSA should consider the development of regulations concerning } \\
\text { the treatment of dark pools. }\end{array}$ \\
\hline
\end{tabular}




\begin{tabular}{|l|l|}
\hline \multicolumn{1}{|c|}{ Principle } & \multicolumn{1}{c|}{ Recommended Action } \\
\hline Principle 37 & The FSA should consider the introduction of a large traders report. \\
\hline
\end{tabular}

\section{Authorities' response}

37. The Japanese authorities welcome the opportunity to be assessed as the first jurisdiction under the new IOSCO Principles and Objectives published in 2010, and the methodologies published in September 2011. The authorities also wish to express their sincere appreciation to the IMF and its experienced assessors for the dedication, time, and resources committed to this assessment. It provided the authorities with an opportunity to comprehensively review their regulatory and supervisory framework through their selfassessments and dialogue with the IMF.

38. The authorities welcome the overall assessment by the IMF that they have achieved a high level of compliance with the IOSCO Principles. The recommendations made by the IMF are generally well received. While some initiatives toward reform have already been taken since the time of the assessment, the authorities will thoroughly take into account these recommendations in their continuous efforts to strengthen their capacities for better regulation and supervision.

39. However, the authorities find that the Methodologies need to be improved further to enable more risk-based assessments with more emphasis on the outcome, not on the form of policy action. Presently, the methodologies provide only a single set of policy actions to be in compliance with each principle, irrespective of a country's risk profile or differences in the effectiveness of the policies depending on the country's circumstances. For example, full compliance with Principle 30 would not be achieved until all market intermediaries holding client assets are subject to external audit, regardless of their risk profile. The authorities maintain that, although external audit would be useful, other measures could also achieve the same objectives. The authorities believe that an excessive emphasis on the form of regulation and supervision could lead to a box-ticking approach which does not lead to the desired outcomes of enhancing market integrity and efficient markets, as well as to ensure financial stability. The authorities will continue to work with the IOSCO and the IMF for further improvement of the methodologies. 


\section{Detailed ASSESSMENT OF IOSCO PRINCIPLES}

40. The purpose of the assessment is primarily to ascertain whether the legal and regulatory securities market requirements of the country and the operations of the securities regulatory authorities in implementing and enforcing these requirements in practice meet the standards set out in the IOSCO Principles. The assessment is to be a means of identifying potential gaps, inconsistencies, weaknesses and areas where further powers and/or better implementation of the existing framework may be necessary and used as a basis for establishing priorities for improvements to the current regulatory scheme.

41. The assessment of the country's observance of each individual Principle is made by assigning to it one of the following assessment categories: fully implemented, broadly implemented, partly implemented, not implemented, and not applicable. The IOSCO assessment methodology provides a set of assessment criteria to be met in respect of each Principle to achieve the designated benchmarks. The methodology recognizes that the means of implementation may vary depending on the domestic context, structure, and stage of development of the country's capital market and acknowledges that regulatory authorities may implement the Principles in many different ways.

- A principle is considered fully implemented when all assessment criteria specified for that Principle are generally met without any significant deficiencies.

- A principle is considered broadly implemented when the exceptions to meeting the assessment criteria specified for that Principle are limited to those specified under the broadly implemented benchmark for that Principle and do not substantially affect the overall adequacy of the regulation that the Principle is intended to address.

- A principle is considered partly implemented when the assessment criteria specified under the partly implemented benchmark for that principle are generally met without any significant deficiencies.

- A principle is considered not implemented when major shortcomings (as specified in the not implemented benchmark for that Principle) are found in adhering to the assessment criteria specified for that Principle.

- A principle is considered not applicable when it does not apply because of the nature of the country's securities market and relevant structural, legal and institutional considerations. 


\section{Table 3. Detailed Assessment of Implementation of the IOSCO Principles}

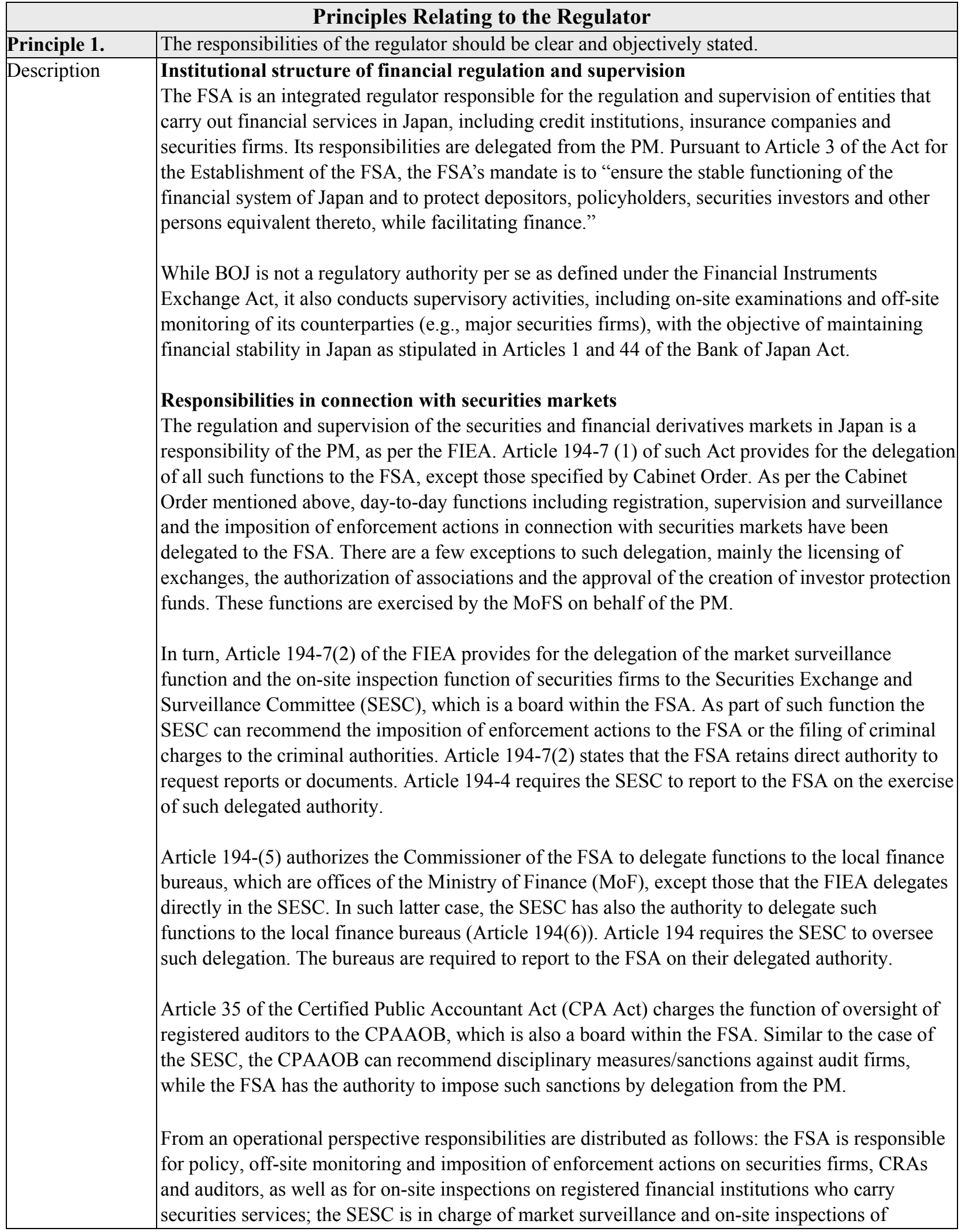


securities firms and the CPAAOB of auditors' oversight. Both the SESC and the CPAAOB can carry out inspections and investigations for purposes of recommending enforcement actions to the FSA. The local finance bureaus conduct the review of securities registration statements and periodic information submitted by issuers, as well as offering documents for tender offers; the registration of financial instruments business operators (FIBOs); and the off-site monitoring and on-site inspections of FIBOs which have capital of less than $¥ 12$ million.

Finally several entities coexist and perform important self-regulatory functions in the securities markets. Their functions are not delegated from the authority of the FSA/SESC, except for the registration of sales representatives which has been delegated by the FSA to the JSDA. However they are required to enforce their rules and oversee their compliance by members. Therefore they are considered SROs for the purposes of Principle 9.

\section{Interpretation}

The FSA can interpret the laws it administers (mainly the FIEA and ITIC) through no action letters and public comments (which allow the public to consult the FSA about the interpretation of financial laws in general, without the need for a particular case in which the law would be applied). In general responses are given within 30 days and inquiries and responses are released on the FSA website.

\section{Gaps or overlaps}

The majority of the functions required for day to day supervision have been delegated to the FSA, the SESC or the CPAAOB. A few functions are still retained by the PM, as indicated above.

In practice, there do not appear to be major overlaps between the FSA, the SESC and the CPAAOB, although the FSA retains authority to request documents and reports on functions exercised by the SESC. Some level of overlap exists vis-à-vis the SROs, in particular in regard to inspections.

There appears to be a level playing field in the provision of securities market activities. Banks and other financial institutions are allowed to conduct certain securities markets activities in connection with retail investors (mainly distribution of collective investment schemes and government securities). In the provision of such activities they are subject to the FIEA and its regulations in connection with the conduct of business issues. In practice in its inspections the FSA does review consumer protection issues and enforcement measures have been imposed on some banks in connection with conduct issues.

\section{Cooperation}

Arrangements for cooperation have been established between the FSA and the SESC. Sharing the same building and a policy of staff rotation fosters informal cooperation and exchange of information. Also, from a legal perspective there is no material obstacle for the sharing of information between the FSA and the SESC.

At an operational level, FSA staff informed that exchange of information from the off-site monitoring (FSA) to the on-site inspections teams (SESC) occurs whenever staff deems it necessary. For example, the FSA shares with the SESC the findings from its off-site monitoring, which the SESC uses as an input to prepare the annual inspections program for issuers and FIBOs. FSA staff also indicated that the flow of information from the banking units to the securities units of the FSA (and the SESC) has also increased over time. In particular in the context of on-site inspections of financial groups, increasingly the two organizations seek to coordinate inspections 


\begin{tabular}{|c|c|}
\hline & $\begin{array}{l}\text { of respectively the banks and the securities firms, and share inspection reports when they deem it } \\
\text { necessary. For the more complex firms, the creation of the OSBM has ensured seamless } \\
\text { cooperation, by incorporating into one unit both off and onsite supervision, with staff from both } \\
\text { the FSA and the SESC. } \\
\text { At a senior level, there are periodic meetings which are attended by executives from the FSA, } \\
\text { SESC and CPAAOB, at least once a week. Also the FSA dedicates a senior officer of director } \\
\text { general class to coordinate all functions related with securities markets and arrange meetings in } \\
\text { various levels. In some cases, SROs are invited to such coordination meetings. } \\
\text { Different mechanisms have been established for coordination with SROs, which are discussed } \\
\text { under Principle } 9 \text {. }\end{array}$ \\
\hline Assessment & Fully Implemented \\
\hline Comments & $\begin{array}{l}\text { The division of responsibilities between the FSA and the SESC increases the need for cooperation } \\
\text { as seamless interaction between off site monitoring and on-site inspections of securities firms is } \\
\text { critical for effective supervision. In addition, exchange of information between banking inspectors } \\
\text { and SESC inspectors enhances the ability of the institution to determine the existence of } \\
\text { widespread conduct issues. Conversations with the FSA and the SESC staff and market } \\
\text { participants lead to conclude that cooperation between the FSA and the SESC has evolved over } \\
\text { time and it is now at a satisfactory level. The authorities are encouraged to consider whether a } \\
\text { similar approach to that used in connection with the OSBM could be extended to other areas of the } \\
\text { organization. }\end{array}$ \\
\hline Principle 2. & $\begin{array}{l}\text { The regulator should be operationally independent and accountable in the exercise of its functions } \\
\text { and powers. }\end{array}$ \\
\hline Description & $\begin{array}{l}\text { Delegated authority and possibility of interference } \\
\text { The FSA, the SESC and the CPAAOB exercise functions in relation to the regulation and } \\
\text { supervision of securities markets as per delegation from the authority of the PM. The scope of } \\
\text { such delegation is defined by a cabinet order. Currently, a few functions (i.e., licensing of } \\
\text { exchanges, authorization of associations and approval of investor protection funds) are retained by } \\
\text { the PM, but exercised by the MoFS on behalf of the PM. FSA staff indicated that the scope of such } \\
\text { delegation has not changed over time. In addition, if changes were to be made, the corresponding } \\
\text { cabinet order would need to be consulted with the government council and a public consultation } \\
\text { would also take place. In connection with functions still retained by the PM, the MoFS is bound by } \\
\text { the legal framework, which establishes the authorization/licensing criteria, and its decisions are } \\
\text { subject to appeal. In addition, FSA staff indicated that in practice the MoFS takes a decision based } \\
\text { on a recommendation of the FSA, and that the MoFS has never taken a different decision from that } \\
\text { recommended by the FSA. } \\
\text { Legal nature of the agencies } \\
\text { The nature of the "agencies" differs. In the first case, the FSA is an agency within the Cabinet. } \\
\text { This means that it is still part of the government, but according to FSA staff, empowered with a } \\
\text { high degree of operational independence in the discharge of its functions. FSA staff indicated that } \\
\text { from a constitutional perspective only a government agency can have enforcement authority. FSA } \\
\text { staff also indicated that other agencies such as the Japan Fair Trade Association and the Consumer } \\
\text { Protection Agency, which need a high degree of independence, have been established with the } \\
\text { same structure as the FSA. In turn, the SESC and the CPAAOB are boards within the FSA; } \\
\text { however by law with a high degree of independence from the FSA since their respective heads, the } \\
\text { Commissioners, are directly appointed by the PM, as is the case for the head of the FSA. } \\
\text { FSA staff indicated that the role of the MoFS, who is commonly referred as the head of the FSA, }\end{array}$ \\
\hline
\end{tabular}


is to be the channel of accountability of the FSA to the government. In such role the MoFS is active on policy discussions (including not only regulation, but also enforcement policies, or inspection policies); but does not interfere on decisions in individual cases.

\section{Stable source of funding}

Regulated entities do not need to contribute to the financing of the FSA. The FSA (including the SESC and the CPAAOB) is funded via the central government budget. Every year the Commissioner of the FSA proposes the amount to be given to the FSA to the MoF. In practice adjustments (decreasing the amount) have been made to the initial proposal submitted by the FSA; however staff emphasized that the final budget allocated to the FSA has been the result of a negotiation between the FSA and the MoF. In addition FSA staff highlighted that the level of resources and staff of the FSA (including the SESC and the CPAAOB) has not suffered cuts overtime.

\section{Terms of appointment}

The FSA is headed by a Commissioner. The Commissioner of the FSA is a civil servant. The law does not stipulate a fixed period for such the appointment.

Article 75 of the NPSA prohibits the dismissal, demotion or placement in administrative leave of the Commissioner of the FSA unless under due cause. Due cause includes mental illness diagnosed by two doctors or poor performance. FSA staff indicated that there has been no precedent where the Commissioner has been demoted, placed on administrative leave or dismissed by the PM. If such a case were to happen, the National Public Service Act requires the reason to be clear and thus staff informed that it would be expected that such reasons be disclosed. FSA staff indicated that it has been the practice that the Commissioner steps down every two to three years, in July at the beginning of the fiscal year, to be substituted by a younger official.

The SESC is headed by one chairman and two commissioners. The CPAAOB is headed by one chairman and up to nine commissioners who must have an understanding and knowledge of matters concerning CPAs. The Commissioners of both the SESC and the CPAAOB are appointed by the PM and are approved by both Diet houses. FSA staff indicated that the Commissioners are not necessarily selected from the current staff. By law they are under fixed term appointment of three years and can be reelected. During their tenure they cannot be demoted unless with due cause.

\section{Accountability}

The FSA is accountable to the National Diet as any other government agency. By law such accountability takes place mainly through the MoFS. While not required by law, the FSA produces an annual report on the discharge of its functions that strengthens accountability. By law, the SESC also produces a report on the authority delegated to it.

By law the financial statements of the FSA have to be audited by the Audit Board of Japan, as is the case for any other administrative agency. The statements along with the audit report are submitted to the Diet.

\section{Transparency}

The FSA and the SESC each disseminate a significant amount of information in regard to its processes, procedures and decisions on individual cases via its website. In particular, the general policy towards regulation, the general policy for inspections, the general policy for administrative actions, and the inspections manuals are included in the website; and so are no-action letters and public comments. 


\begin{tabular}{|c|c|}
\hline & $\begin{array}{l}\text { The SESC makes public the recommendations for regulatory actions that it has submitted to the } \\
\text { FSA and to the criminal authorities. In turn, the FSA discloses regulatory actions taken against } \\
\text { individuals and firms including enforcement actions and orders for improvement directed to } \\
\text { regulated entities - except for orders related to financial soundness which are not disclosed. In } \\
\text { such releases the FSA specifies the facts and the legal basis for the actions taken. } \\
\text { The annual reports of the FSA and the SESC are available in the website and so are reports from } \\
\text { the CPAOB on its findings regarding reviews of auditors. } \\
\text { Finally the website also contains copies of relevant laws. The most important laws (such as the } \\
\text { FIEA) and policy documents are available in English and so are the annual reports of the SESC. } \\
\text { Individual redress } \\
\text { A person or firm subject to a particular action can request a review of the action to the authority. In } \\
\text { addition, it can bring an administrative lawsuit to the court. Also, under the Administrative } \\
\text { Procedure Act, when a registration is cancelled, or an enforcement action is to be imposed, the } \\
\text { affected party has the right to receive notice and a hearing (Article } 13 \text { of the APA). } \\
\text { Confidentiality } \\
\text { Confidentiality obligations are stipulated for information on individuals and information on } \\
\text { corporations under the Information Disclosure Act (Article 5). }\end{array}$ \\
\hline Assessment & Broadly Implemented \\
\hline Comments & $\begin{array}{l}\text { Questions } 1,2,3 \text {, and } 5 \text {, of the methodology require the regulator to be independent, by looking at } \\
\text { different features of the system from the governance structure, and funding arrangements to } \\
\text { whether evidence of interference in daily decisions can be found. } \\
\text { In the case of Japan, several features of the legal framework might pose a threat to FSA's } \\
\text { independence and its ability to carry out its functions effectively: } \\
\text { - The legal nature of the agency and the fact that the scope of such authority is defined by } \\
\text { cabinet order rather than by law (as a cabinet order defines the functions that are retained by } \\
\text { the PM). } \\
\text { The fact that the initial budget proposal of the FSA has been subject to adjustments during the } \\
\text { process of discussion with the MoF. } \\
\text { The fact that functions can be (and in fact are) delegated to the local finance bureaus, which } \\
\text { are part of the MoF. } \\
\text { The fact that certain functions are retained by the PM. } \\
\text { In addition, the lack of a term limit for the Commissioner can weaken accountability. } \\
\text { Assessors acknowledge that the functions of the FSA have remained the same over time. } \\
\text { Functions retained by the PM are limited and there is a clear and transparent process in place. The } \\
\text { FSA and the SESC have established adequate arrangements to oversee the work carried out by the } \\
\text { local finance bureaus. There is evidence that resources have increased over time although in the } \\
\text { opinion of the assessors they are not yet at the optimal level, and therefore additional concerns } \\
\text { related to the level of resources have been reflected in Principle } 3 \text {. Finally, the assessors did not } \\
\text { find evidence of interference of the MoFS in individual decisions. As for accountability, in }\end{array}$ \\
\hline
\end{tabular}




\begin{tabular}{|c|c|c|}
\hline & \multicolumn{2}{|c|}{$\begin{array}{l}\text { practice a term limit has operated as the Commissioner steps down every two to three years and } \\
\text { there is strong accountability by way of the participation of the MoFS in policy decisions, and } \\
\text { FSA reporting. Thus, the assessors conclude that at this point in time, the legal features described } \\
\text { above have not translated into material breaches to independence. That is the reason for the grade, } \\
\text { in spite of the legal framework. Nevertheless the assessors encourage the authorities to consider } \\
\text { the legal framework further to strengthen the operational independence of the FSA. }\end{array}$} \\
\hline Principle 3. & \multicolumn{2}{|c|}{$\begin{array}{l}\text { The regulator should have adequate powers, proper resources and the capacity to perform its } \\
\text { functions and exercise its powers. }\end{array}$} \\
\hline Description & $\begin{array}{l}\text { Powers } \\
\text { The FSA together with the SESC have be } \\
\text { entities: } \\
\text { - Register entities that want to engage } \\
\text { cancel or suspend such registration, } \\
\text { - Register issues of public offering, in } \\
\text { statements } \\
\text { - Supervise regulated entities (includin } \\
\text { issuers (including off-site reporting; } \\
\text { circumstances) } \\
\text { Impose monetary penalties, for the } m \\
\text { connection with issuers, CIS and unf } \\
\text { - Seek cease and desist orders against } \\
\text { - File criminal charges and investigati } \\
\text { A few functions are still retained by the } \mathrm{F} \\
\text { investor protection funds and the authori } \\
\text { Resources } \\
\text { The FSA (including the SESC and the FS } \\
\text { universe of entities, including: }\end{array}$ & $\begin{array}{l}\text { wers in connection to regulated } \\
\text { BOs) as well as to rescind, } \\
\text { e or suspend their business } \\
\text { nendments to registration } \\
\text { a-site inspections), as well as } \\
\text { mitted under certain } \\
\text { egislation such as the FIEA in } \\
\text { the FIEA } \\
\text { ons. }\end{array}$ \\
\hline & \multicolumn{2}{|c|}{ Number of Regulated Entities under the IOSCO Assessment } \\
\hline & Issuers & 2900 \\
\hline & Type I FIBO & 322 \\
\hline & Type II FIBO & 1,293 \\
\hline & IMBO & 323 \\
\hline & Investment Advisory Business & 1,122 \\
\hline & Registered Financial Institutions & 1,136 \\
\hline & Exchanges & 6 \\
\hline & PTS & 5 \\
\hline & Credit Rating Agencies & 6 \\
\hline & \multicolumn{2}{|c|}{$\begin{array}{l}\text { As per statistics provided by the FSA from fiscal year } 2003 \text { - when the first assessment took } \\
\text { place- to FY } 2011 \text { the budget of the FSA has grown by } 40 \text { percent. The FSA and SESC increased } \\
\text { their staff each year, resulting in about } 30 \text { percent more staff in FY } 2011 \text { compared to FY } 2003 \text {. }\end{array}$} \\
\hline
\end{tabular}


FSA staff highlighted that such trend has not been the case for the rest of the government, where the number of staff has decreased by roughly 41 percent.

\begin{tabular}{|l|l|l|l|l|}
\hline FSA, SESC, CPAAOB Staff & 2002 & 2009 & 2010 & 2011 \\
\hline FSA (directly related to capital markets) & 63 & 117 & 131 & $\mathbf{1 4 5}$ \\
\hline SESC & 182 & 374 & 384 & $\mathbf{3 9 2}$ \\
\hline Coordination & 118 & 16 & 16 & 16 \\
\hline Market Surveillance & & 46 & 48 & 49 \\
\cline { 1 - 3 } Inspection & & 110 & 113 & 118 \\
\hline \begin{tabular}{lllll|} 
Civil Penalties and Disclosure \\
Documents Division
\end{tabular} & & 100 & - \\
\hline Administrative Money Penalties & & - & - & 62 \\
\hline Disclosure Statement Division & & - & - & 39 \\
\hline Investigation Division & 62 & 103 & 104 & 105 \\
\hline CPAAOB & - & 55 & 58 & $\mathbf{5 7}$ \\
\hline
\end{tabular}

Information technology systems such as a "Data System for On-site and Off-site Supervision" and an "Off-site Monitoring System" have been developed in order to store and use data and materials submitted from financial institutions in an efficient manner. In addition all information from issuers is received electronically and entered into a database called EDINET, which is accessible to the public.

\section{Capacity to hire and retained qualified staff}

FSA staff is mostly composed of civil service staff. The salaries of FSA personnel are determined and paid in accordance with the Remuneration Act. According to such Act the National Personnel Authority makes a recommendation on salaries for the whole administration based on private sector salaries (any business with more than 50 employees). However, since the reference is broader than financial sector salaries, in practice the salaries of FSA staff are not comparable with the salaries paid by the financial sector. The level of turnover is very low (less than two percent for the last three years).

Recruiting of specialists such as market experts, CPAs, and lawyers is mostly done in the form of fixed term contracts (from three to five years), and pursuant to the Act on Special Measures of Employment and Remuneration of Officials with Fixed Term of Office in the Regular Service (effective since November 27, 2000) which allows the FSA to pay them more competitive salaries. In this regard, 111 market experts, 43 CPAs and 21 lawyers have been recruited for securities related departments during the last years. By law the FSA is not able to employ staff with a fixed term for more than five years. However, FSA staff indicated that many experts initially hired on fixed term appointments and that hope to continue working for the FSA tend to be employed permanently.

\section{Training}

The FSA launched the Financial Research and Training Center in 2001, aimed at effective coordination between "research" and "training" for FSA staff. The FSA provides training at various levels corresponding to the functions/responsibilities of each division, and the experience and capacity of its staff, including highly technical programs on risk management. The training is composed of both lectures and discussions, and provides knowledge of financial inspection and supervision and case studies. Lecturers are not only from its internal staff but also academics and private sector experts, such as lawyers, and CPAs.

In addition, the FSA provides ample opportunity to its career staff by exchanging staff with 


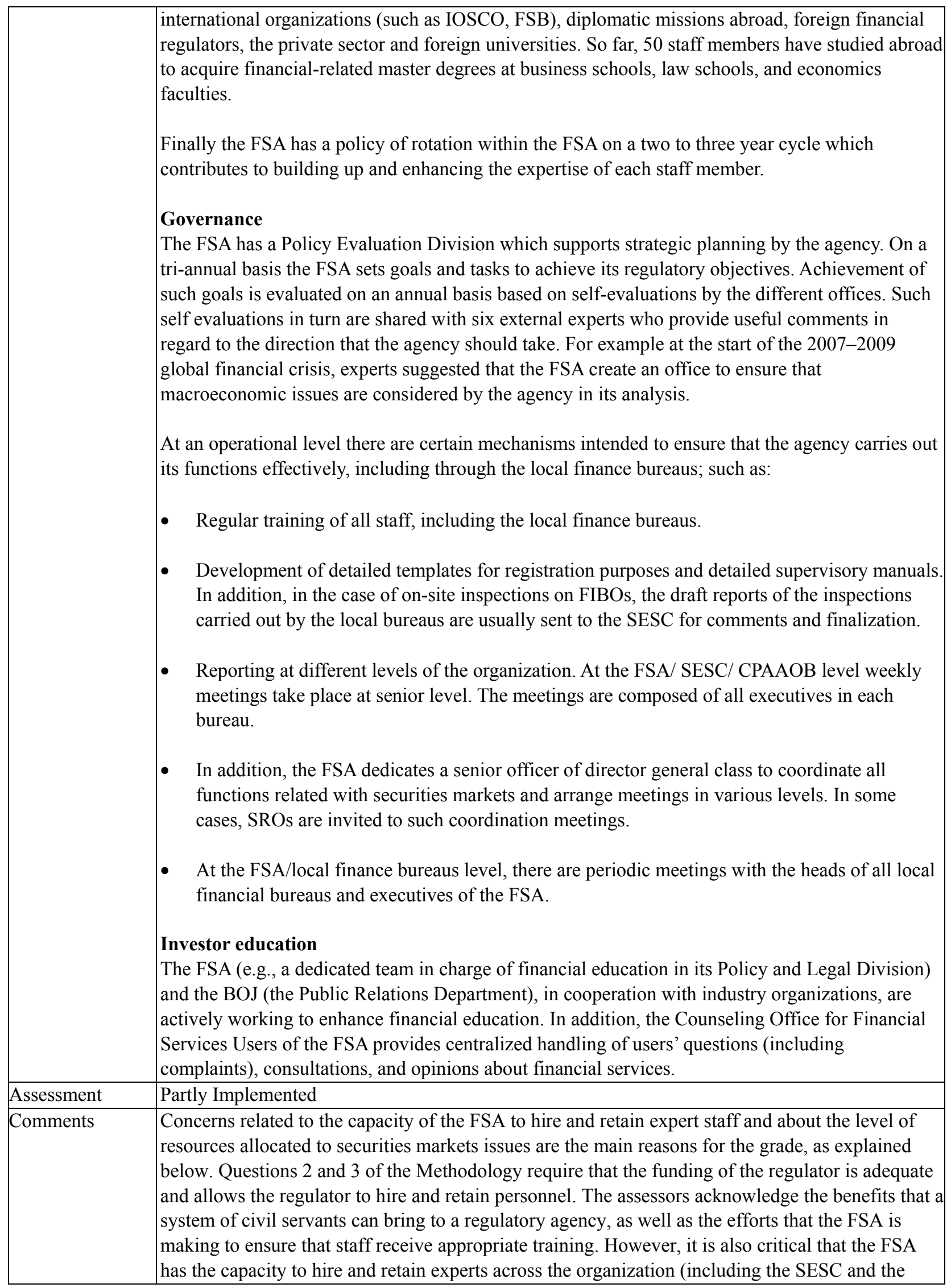




\begin{tabular}{|c|c|}
\hline & $\begin{array}{l}\text { CPAAOB). It is in this regard that the current civil service regime poses important challenges that } \\
\text { should be addressed, in particular given the complexity of the structure of the Japanese market. In } \\
\text { addition, the assessors are concerned about whether enough resources are being dedicated to } \\
\text { inspection and the effect that such allocation might have in the overall effectiveness of the } \\
\text { supervisory system. In this regard, the assessors encourage the authorities to conduct a } \\
\text { comprehensive assessment of the risks to the regulatory objectives of the FSA that could serve as a } \\
\text { basis for decisions on resources. } \\
\text { Key Question } 5 \text { requires the existence of governance arrangements to ensure that the regulator } \\
\text { effectively discharge its functions. As indicated in the description of this Principle, from an } \\
\text { operational perspective the existence of two main bodies in charge of securities markets } \\
\text { (FSA/SESC), one responsible for off-site monitoring and the other for market surveillance and on- } \\
\text { site inspections creates challenges for effective discharge of functions. Such challenges are } \\
\text { compounded by the broad delegation of functions into the local finance bureaus, as well as the use } \\
\text { of SROs for different functions. The assessors acknowledge that the FSA has established a set of } \\
\text { mechanisms that seek to address these challenges. It would be useful if additional mechanisms to } \\
\text { assess the quality of the work carried out by the different departments are developed. However this } \\
\text { issue has not been taken into consideration for the grade. } \\
\text { Finally, Key Question } 1 \text { of the Methodology requires that a regulator has sufficient powers. In the } \\
\text { context of Japan, the PM retains the licensing over exchanges, the authorization of associations } \\
\text { and of investor protection funds. In the opinion of the assessors retention of such powers has not } \\
\text { affected day to day functions, and therefore has not been taken into consideration for the grade. } \\
\text { The power to impose money penalties is limited. This issue has been discussed under Principle } 11 .\end{array}$ \\
\hline Principle 4. & The regulator should adopt clear and consistent regulatory processes. \\
\hline Description & $\begin{array}{l}\text { Consultation of regulations } \\
\text { As any other government agency, the FSA is required to follow a public comment process to } \\
\text { develop or amend regulations. The consultation process also includes cost-benefit analysis and } \\
\text { analysis of alternatives. Such analysis is done internally, although the FSA might use as input for } \\
\text { the process work done by academics and experts. At the end of the consultation process, the FSA } \\
\text { includes in the website the regulations enacted, along with an explanation/ opinion on the } \\
\text { comments provided. Furthermore, major introductions and amendments of laws and regulations } \\
\text { are released on the website with explanatory materials. } \\
\text { In addition, all government agencies including the FSA are required to respond to requests for } \\
\text { interpretation from the public on the laws and regulations they administer. Such requests are } \\
\text { analyzed by the corresponding agency and the opinion of the authority published. } \\
\text { Supervisory policies and actions } \\
\text { Laws, ordinances and regulations, which set up the requirements for licenses as well as the basis } \\
\text { for supervisory actions are published on the website of the FSA. The FSA, the SESC, and the } \\
\text { CPAAOB also disclose their Annual Plans. In addition, the Supervisory Guidelines and the } \\
\text { Inspection Manuals are publicly available on the website. } \\
\text { The SESC makes public all recommendations for regulatory actions that it submits to the FSA and } \\
\text { all prosecutions to the criminal authorities. In turn, the FSA discloses all regulatory actions } \\
\text { imposed on regulated entities, including orders for business improvement-except those related to } \\
\text { financial soundness. In such releases, the FSA specifies the facts and the legal foundation for the } \\
\text { action taken. The SESC inspection summary results are published on the SESC website to ensure } \\
\text { the transparency of program operations, fair program execution and contribution to investor } \\
\text { protection. }\end{array}$ \\
\hline
\end{tabular}




\begin{tabular}{|c|c|}
\hline & $\begin{array}{l}\text { In addition, to enhance the transparency and predictability of the action, administrative criteria and } \\
\text { case studies of regulatory actions are published. } \\
\text { Due process } \\
\text { The FSA is bound by the Administrative Procedures Act (APA), which subjects it to certain rules } \\
\text { of due process. In particular, when an adverse action is made, its reasons must be presented. The } \\
\text { APA and other related regulations do not specifically require that this be in writing. However, in } \\
\text { practice, reasons for regulatory actions are presented in writing, and notice of the inspection results } \\
\text { is provided in writing. } \\
\text { A person or firm subject to a particular action can request a review of the action to the authority. In } \\
\text { addition, it can bring an administrative lawsuit to the court. } \\
\text { Also, under the Administrative Procedure Act, when a registration is cancelled, the FIBO has the } \\
\text { right to receive notice and a hearing (Article } 13 \text { of the Administrative Procedure Act). } \\
\text { Confidentiality } \\
\text { Confidentiality obligations are stipulated for information on individuals and information on } \\
\text { corporations under the Information Disclosure Act (Article 5). }\end{array}$ \\
\hline Assessment & Fully Implemented \\
\hline Comments & \\
\hline Principle 5. & $\begin{array}{l}\text { The staff of the regulator should observe the highest professional standards, including appropriate } \\
\text { standards of confidentiality. }\end{array}$ \\
\hline Description & $\begin{array}{l}\text { Ethics guidance } \\
\text { The staff of the FSA is subject to the National Public Service Act and the National Public Service } \\
\text { Ethics Act. The NPSA requires public officials to act in the public interest (Article 96). In } \\
\text { addition, the NPSEA imposes duties of fairness and neutrality, prohibition to use a public position } \\
\text { for private interests and avoidance of any conduct that could bring distrust to citizens (Article 3). } \\
\text { The NPSEA also requires submission of certain reports by officials above a certain rank, } \\
\text { including: } \\
\text { - Gifts above ¥5,000 (Article 6) } \\
\text { Annual report on trading of shares (Article7) } \\
\text { Annual income report (Article } 8 \text { ) } \\
\text { Violations of the National Public Services Act and the National Public Service Ethics Act are } \\
\text { subject to penalty and other disciplinary actions. } \\
\text { The FSA has developed its own guidelines in connection with securities and derivatives } \\
\text { transactions. Such guidelines prohibit the sale and purchase of stocks of financial institutions } \\
\text { subject to the supervision of the FSA. For other types of securities the guidelines prohibit short } \\
\text { term transactions (six months or less), and derivative transactions. Staff is required to submit an } \\
\text { annual report on the financial transactions carried out. } \\
\text { The FSA has also developed additional guidance in connection with the management of conflicts } \\
\text { of interest. In particular there is a cool off policy in place whereby former FSA officials cannot } \\
\text { engage with the FSA in connection with applications from regulated entities for a period of three } \\
\text { years. By practice inspectors who have had a former employment relationship with a regulated } \\
\text { entity cannot be assigned to inspections of such entity. }\end{array}$ \\
\hline
\end{tabular}




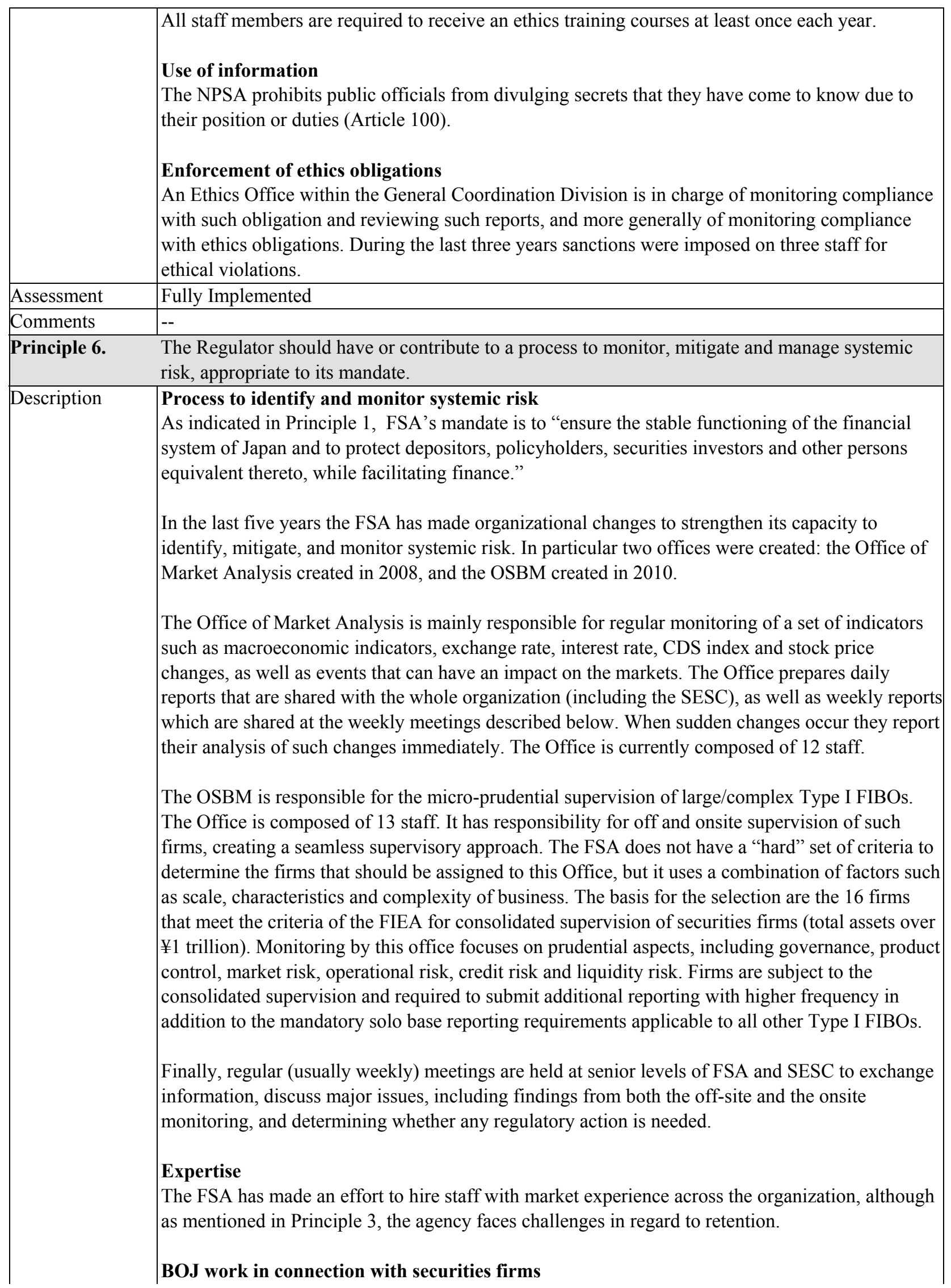


Aside from the FSA, BOJ also assumes responsibility to maintain sound financial system. One of the core purposes of BOJ, as stipulated in Article 1, Paragraph 2 of the Bank of Japan Act, is to ensure smooth settlement of funds among financial institutions, thereby contributing to the maintenance of financial system stability. BOJ conducts on-site examinations of its counterparty securities firms, as stipulated in Article 44 of the Bank of Japan Act, by dispatching examiners to the firms. There are currently 34 Type I firms with accounts at the BOJ. Overall such firms are those that participate in wholesale business and monetary operations. Based on article 44 of the BoJ Act the BoJ concludes contracts with such firms that stipulate the right of the BoJ to seek information and conduct examinations on them.

BOJ also conducts off-site monitoring, through meetings and telephone interviews with the executives and staff of the firms, as well as analyses of various documents and financial data. Off site reporting includes:

- Quarterly reports which include detailed information of different types of risk, as well as risk management; and

- Daily liquidity reports.

In addition, regular calls usually follow such reports. If the BOJ considers that there are issues of concern, it asks additional questions as well as a plan of action to address such concerns.

Financial Institutions Surveillance Division carries out monthly presentations on the major activities of the financial institutions to the policy board of the BOJ.

From a broader perspective the BOJ produces Financial System Report (FSR) biannually, with the aim of presenting a comprehensive analysis and assessment of Japan's financial stability, and facilitating communication with concerned parties.

\section{Coordination between FSA-BOJ in connection with large complex firms}

There are no memoranda of understanding for cooperation and exchange of information with the BOJ. However staff informed of the existence of a set of arrangements for cooperation including:

- Regular exchange of a list of contacts;

- Regular exchange of the schedule of inspections; and

- $\quad$ Ad-hoc meetings and calls.

In addition, Article 44 of the BOJ Act authorizes the FSA to request the BOJ for the reports of their onsite examinations on securities firms that have accounts at the BOJ. In practice, information exchanges take place on a regular basis to discuss the findings from both sides, instead of the FSA making such formal request to the BOJ.

Staff indicated that regular calls (usually monthly in "normal" times, and more frequently during "crisis" times) take place between the BOJ and the OSBM, whereby they seek each other's views in connection with the financial situation of these institutions and coordinate as necessary. Examples were provided of effective coordination and exchange of information in the context of the current European sovereign debt crisis. 


\begin{tabular}{|c|c|}
\hline & $\begin{array}{l}\text { Additional mechanism to address financial stability } \\
\text { Article } 38 \text { of the BOJ Act authorizes the BOJ on the request of the PM and the MoF to "conduct } \\
\text { the business necessary to maintain stability of the financial system, such as to provide loans to the } \\
\text { financial institution pertaining to said consultation." Such article would allow the BOJ to provide } \\
\text { financing to a securities firm which failure could give rise to financial stability concerns. Such } \\
\text { authority was used in the past in connection with the failure of Yamaichi Securities. } \\
\text { Cross border cooperation } \\
\text { A supervisory college and a crisis management group were created in } 2010 \text { for a large complex } \\
\text { firm, with the objective of fostering a comprehensive analysis of its operations. Both the FSA and } \\
\text { the BOJ participate in the college, along with the regulators from the jurisdictions where the firm } \\
\text { has major operations. The FSA and the BOJ share a set of information with the other supervisors, } \\
\text { meetings take place on an annual basis and there are also calls on a semiannual basis. In the } \\
\text { context of the crisis management group the regulators have discussed possible measures to deal } \\
\text { with crisis situations. } \\
\text { In addition, the FSA and the BOJ are members of the supervisory colleges for large investment } \\
\text { banks with operations in Japan. The foreign regulator shares information with all the members of } \\
\text { the college. The colleges meet once a year and have conference calls on a semiannual basis. }\end{array}$ \\
\hline Assessment & Broadly Implemented \\
\hline Comments & 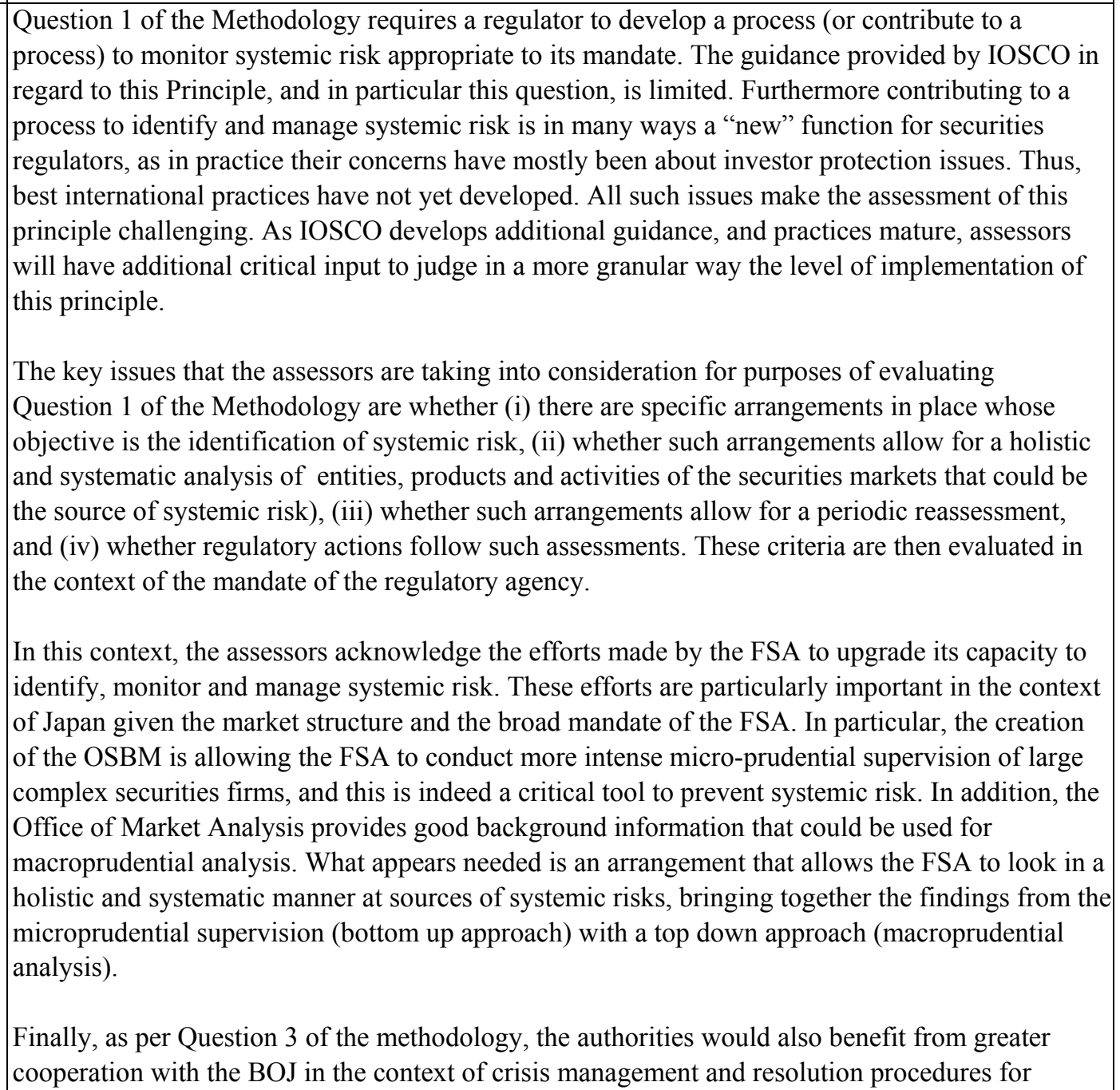 \\
\hline
\end{tabular}




\begin{tabular}{|c|c|}
\hline & systemically important institutions, including large complex securities firms. \\
\hline Principle 7. & $\begin{array}{l}\text { The Regulator should have or contribute to a process to review the perimeter of regulation } \\
\text { regularly. }\end{array}$ \\
\hline Description & $\begin{array}{l}\text { Formally there is not a unit or office singled out for reviewing the perimeter of regulation. } \\
\text { In practice the two offices described above play an important role in identifying risks coming from } \\
\text { the market (Office of Market Analysis) or from the large complex institutions (OSBM). In } \\
\text { addition, the off-site monitoring and on-site inspection functions serve as vehicles to continually } \\
\text { assess the extent to which previous assumptions about regulated entities and products, and their } \\
\text { level of risks remain valid. For example, through its analysis of findings from inspections the } \\
\text { SESC has identified areas to focus on, such as entities that are distributing products (CIS) without } \\
\text { being registered with the FSA. In such particular area, its findings have led to collaboration with } \\
\text { the police to bring injunctions against unlicensed firms that could also be involved in more serious } \\
\text { offenses such as fraud. } \\
\text { Findings from such functions have also lead to changes in regulation, and even laws. In particular } \\
\text { in regard to legal changes, the FSA submits almost every year proposals to amend FIEA and/or } \\
\text { other financial acts to the Diet. Furthermore staff informed that the Diet considers these request in } \\
\text { an expedited manner and amendments to the relevant laws are frequent. } \\
\text { Specific examples are as follows: } \\
\text { The } 2010 \text { amendment to the FIEA, introducing (i) consolidated regulation of FIBOs of a } \\
\text { certain size to overcome regulatory weaknesses, and (ii) mandatory clearing for OTC } \\
\text { derivative transactions in accordance with international regulatory discussions for OTC } \\
\text { derivatives to be implemented by } 2012 \text {. } \\
\text { The } 2011 \text { amendment to the FIEA, whereby the reasons for refusal of the registration for } \\
\text { Investment Advisory and Agency Business were improved as a result of a proposal by the } \\
\text { SESC. }\end{array}$ \\
\hline Assessment & Broadly Implemented \\
\hline Comments & $\begin{array}{l}\text { Questions 1,2, and } 3 \text { of the Methodology require regulators to have processes in place to evaluate } \\
\text { the perimeter of regulation. The assessors acknowledge that guidance by IOSCO in regard to this } \\
\text { Principle is limited, and best practices have not emerged yet. Both issues make the assessment of } \\
\text { this Principle challenging. As IOSCO develops additional guidance, and practices mature, } \\
\text { assessors will have additional critical input to judge in a more granular way the level of } \\
\text { implementation of this Principle. } \\
\text { The key issues that the assessors are taking into consideration for purposes of evaluating questions } \\
1,2 \text { and } 3 \text {, of the Methodology are whether (i) there are specific arrangements in place whose } \\
\text { objective is the review of the perimeter of regulation, (ii) whether such arrangements allow for a } \\
\text { holistic and systematic analysis of entities, products and activities of the securities markets that } \\
\text { could be the source of risks to the regulatory objectives, (iii) whether such arrangements allow for } \\
\text { periodic reassessment of risks and (iv) whether actions follow such assessments. } \\
\text { In such context, the assessors believe that the FSA is actively using its ordinary functions and } \\
\text { meetings at senior level as vehicles to identify emerging risks and address problems with the } \\
\text { perimeter of regulation. Clear examples were provided as indicated above. However, the current } \\
\text { system would benefit from the development of a more robust framework that allows the FSA to } \\
\text { identify and prioritize risks cutting across all departments and divisions, determine their potential }\end{array}$ \\
\hline
\end{tabular}




\begin{tabular}{|c|c|}
\hline & scale and scope, and thus whether there is a need for regulatory action. \\
\hline Principle 8. & $\begin{array}{l}\text { The Regulator should seek to ensure that conflicts of interest and misalignment of incentives are } \\
\text { avoided, eliminated, disclosed or otherwise managed. }\end{array}$ \\
\hline Description & 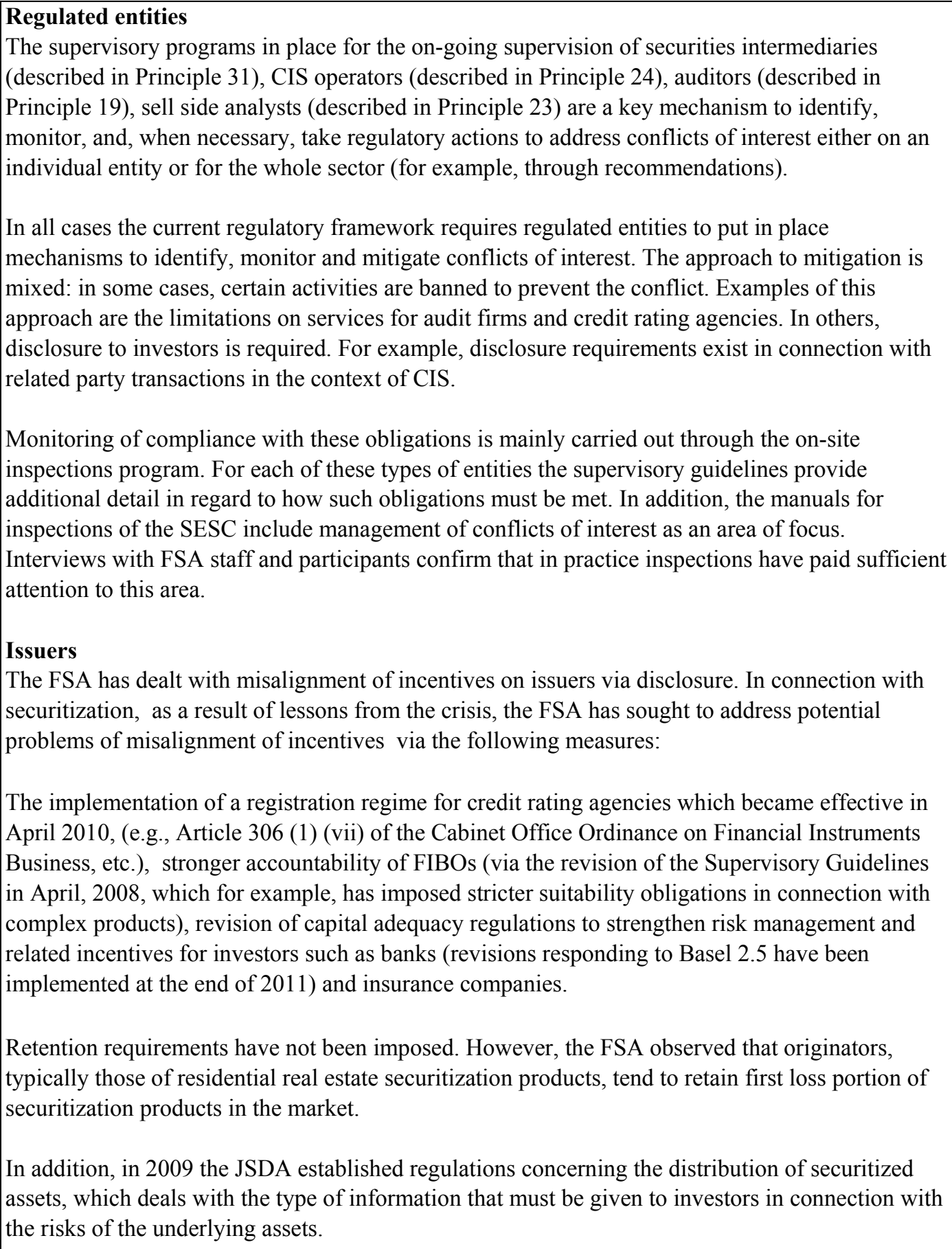 \\
\hline Assessment & Fully Implemented \\
\hline Comments & $\begin{array}{l}\text { In connection with regulated entities, requirements for management of conflict of interest are } \\
\text { imbedded throughout the IOSCO Principles, including the Principles for SROs, auditors, CRAs, } \\
\text { sell-side analysts CIS, and securities intermediaries. Given the limited guidance by IOSCO, this } \\
\text { assessment has focused on evaluating whether such requirements are in place and whether through }\end{array}$ \\
\hline
\end{tabular}




\begin{tabular}{|c|c|}
\hline & $\begin{array}{l}\text { its ordinary supervisory program the regulator seeks to ensure that they are met. } \\
\text { In connection with issuers, the assessors note a concern in the market regarding the robustness of } \\
\text { corporate governance. The FSA and the TSE are aware of such concerns, and actions have been } \\
\text { taken in recent years. In this regard, for example, the FSA strengthened disclosure requirements in } \\
\text { connection with the securities registration statement in 2010. Also, after the Olympus incident, the } \\
\text { FSA and the TSE have embarked in a review of current corporate governance requirements, as } \\
\text { well as the quality control review of auditors to determine whether additional regulatory actions } \\
\text { are needed. } \\
\text { In addition, the assessors have looked at whether there is some specific type of product where } \\
\text { misalignment of incentives is prevalent. The information provided by the FSA lead to conclude } \\
\text { that the FSA has looked actively at the securitization market to assess the degree to which } \\
\text { problems of misalignment of incentives are present and has taken regulatory measures to mitigate } \\
\text { the possibility of such problems. }\end{array}$ \\
\hline & Principles for Self-Regulation \\
\hline Principle 9. & $\begin{array}{l}\text { Where the regulatory system makes use of SROs that exercise some direct oversight responsibility } \\
\text { for their respective areas of competence, such SROs should be subject to the oversight of the } \\
\text { Regulator and should observe standards of fairness and confidentiality when exercising powers and } \\
\text { delegated responsibilities. }\end{array}$ \\
\hline Description & $\begin{array}{l}\text { Types of entities that can perform self-regulatory functions in Japan } \\
\text { Three types of entities can perform self-regulatory functions: } \\
\text { - The exchanges (licensed under FIEA Article 80). } \\
\text { Associations, which comprise two different types: one authorized under FIEA } \\
\text { Article 67-2(JSDA) and the other approved under FIEA Article } 78 \text { (ITAJ). } \\
\text { - Self-regulatory organizations established by exchanges (authorized under FIEA } \\
\text { Article 102-14). } \\
\text { In practice, self-regulatory functions are performed by the securities exchanges (Tokyo, Osaka, } \\
\text { Nagoya, Sapporo, Fukuoka, and Tokyo AIM), TSE SRO, and the associations JSDA and ITAJ, } \\
\text { although the nature of the functions differs according to the business of the members. There are } \\
\text { two additional associations: the JSIAA and the Type II FIA. The JSIAA has rulemaking functions } \\
\text { in connection with investment advisers, and has subject them to off-site reporting; however, it does } \\
\text { not conduct on-site inspections nor enforcement functions-although it can withdraw license. The } \\
\text { Type II FIFA has full self regulatory functions in connection with Type II FIBOs; but is of very } \\
\text { recent creation. Therefore the assessment has not covered these two associations. } \\
\text { Functions of each SRO are as follows: } \\
\text { - Exchanges: Listing authority, admission of members to trading which are obliged to comply } \\
\text { with business rules for access to their markets, market surveillance and inspection of members } \\
\text { (the latter two are not functions of the TSE as it has constituted a separate SRO). } \\
\text { - JSDA: A trade association which at the same time performs SRO functions related to rule } \\
\text { making, inspections, disciplinary action, and accreditation of sales representatives and } \\
\text { disclosure of trading information. Its members are Type I FIBOs and Registered Financial } \\
\text { Institutions. For members of the stock exchanges membership in the JSDA is mandatory. Sales }\end{array}$ \\
\hline
\end{tabular}


representatives' qualification is compulsory for employment and annual requalification is mandatory.

- ITAJ: A trade association with similar SRO functions to the JSDA in this case related to IMBOs. Although membership is voluntary all IMBOs are members since under FIEA members that are not part of an association would be directly overseen by the PM.

- TSE SRO: It is responsible for examination and taking disciplinary action in respect of members of TSE (the TSE Group is the only exchange to have established a separate SRO for these functions).

\section{Conditions for approval}

All three types of SROs require some form of government "approval/authorization." In all cases applications are reviewed by the FSA for compliance with the conditions set forth in FIEA. In the case of the exchanges the license is given by the MoFS on behalf of the PM, on the recommendation of the FSA. For Associations, the formal authorization or approval is granted by the Commissioner of the FSA.

The set of basic criteria for registration, authorization or approval applicable to all three types of SROs are essentially the same and include:

- Capacity to carry out the mandate, which includes requirements for adequate resources and personnel structure: (FIEA Article 82 and 102-16). Capital requirements, however, only apply to exchanges.

- Submit their articles of incorporation/operational rules and brokerage contract rules for "smooth transactions" that protect investors to the FSA (FIEA Articles 82 for exchanges, 102-16 SROs and 79-3 for associations).

- Manage conflicts of interest (FIEA Articles 87-5 for exchanges, 102-23 for SROs and 78-2 for associations).

- Manage and protect as required by law confidential information received (FIEA Articles 87-8 for exchanges and SROs and 79 for associations).

- Sanction members (FIEA Articles 87 for exchanges and SROs and 79-2 for associations).

- Fair treatment of members (FIEA Articles 87-9 for exchanges, 68 for SROs and 79-6 for associations).

- Cooperation with the regulator (FIEA Articles 153 for exchanges, 73 for SROs and 79-5 for associations).

Authorization from the FSA is required for any material change to the articles of incorporation, operational rules or brokerage contract rules (FIEA Article 149). The FSA must be notified if changes are to be made to other rules. SRO's must keep records and prepare reports as required by FIEA (FIEA Article 188).

This set of basic criteria continues to be applicable to the SRO on an ongoing basis and the FSA may take action should there be noncompliance with these provisions at any time. 


\section{Powers of the FSA over SROs}

Once approved, the FSA has the following specific powers over all SROs:

- Authority to inspect operations (FIEA Article 151)

- Ability to suspend business operations (also to dismiss executives in authority) (FIEA Article 150)

- Require reports of operations (FIEA Article 151)

- Approval of rule changes and direction to change rules (FIEA Article 149, 153)

- Issue orders for improvement (Supervisory Guidelines IV).

\section{Authority of the FSA versus SROs}

The FIEA does not delegate any of the FSA/SESC authority to the SROs, except for registration work of sales representatives (FIEA Article 64-7), thus the FSA retains full authority to exercise its powers and responsibilities. In practice the FSA has endorsed the role of SROs (mentioned specifically in the Supervisory Guidelines) and the SROs are required to enforce their rules as a matter of law.

\section{Coordination/oversight}

There are no formal MoUs in place with any of the SROs. In the opinion of the authorities such MoUs are not necessary because in all cases the nature and functions of the SROs are defined by law. From an operational perspective the authorities highlighted the existence of several arrangements to foster coordination, including regular calls, formal meetings and oversight through off- site reporting and on-site inspections, which has been tailored to the functions performed by each SRO.

\section{Exchanges}

The oversight that the FSA/SESC performs over exchanges is explained under Principle 35. One particularity of the TSE is that it transferred the majority of its SRO functions to a separate legal entity. Thus oversight by FSA in respect to SRO functions focuses on TSE SRO. The TSE however has retained responsibilities for listing and delisting. Accordingly it reports on listings and de-listings to the FSA.

\section{JSDA}

Off-site

The JSDA is required to submit several reports to the FSA/SESC

- A "Report of Actions" concerning the noncompliance of member organizations with the applicable rules and law as and when such occur.

- Results of its member inspections on a quarterly basis

- Disciplinary actions taken: reporting occurs when a sanction is imposed on a member.

- An annual report on its activities (FIEA Article 76).

In addition, according to FSA/JSDA staff there is regular contact between the JSDA and FSA officials (usually daily) concerning the various aspects of its functions including the conduct of inspections, and warnings given about operational issues. 
On site

The JSDA and the SESC meet three times a year to discuss issues relating to the supervisory program of the JSDA. In addition there is a monthly meeting at a senior level of both organizations to discuss coordination and planning of activities. This meeting is designed to ensure that the scope of the SESC inspection plan is known to the JSDA and so that there are no overlaps in the inspection program to be conducted of the participants by each organization.

In addition, the SESC conducts inspections of the JSDA's SRO responsibilities. The SESC has no specific cycle of inspections for the JSDA and the last formal in depth inspection was conducted in 2006. Such inspection lasted for approximately one month. It was a comprehensive review of the JSDA which was fully documented. The written report included relevant working papers as evidence for the findings and guidance issued by SESC at the conclusion of the inspection.

\section{ITAJ}

Off-site

The arrangements are the same for ITAJ as set above for JSDA as the same reporting obligations apply (serious events are reported as they occur) as well as annual report requirement and regular dialogue between officials.

On-site

As above, the SESC conducts inspections of ITAJ's SRO responsibilities, but the SESC has not defined an inspection cycle. The last inspection was completed in 2007 and is fully documented

SESC does not have official meetings like those described above for JSDA but the FSA, the SESC and ITAJs senior management meet once per year to discuss industry developments and exchange views. There are also discussions about specific member issues as they arise.

\section{TSE SRO}

Off-site

Similar arrangements as those described for the JSDA apply to TSE SRO. The TSE SRO reports separately to the reporting by TSE as it is a separate legal entity and has different functions. In addition, the TSE SRO must report any rule change and disciplinary action.

On-site

The SESC does not have a fixed inspection cycle for TSE SRO. The last formal in depth inspection was conducted in 2009. Such inspection lasted for 42 business days. It was a comprehensive review of the TSE SRO which was fully documented in a written report. The report included relevant working papers as evidence for the findings and guidance issued by SESC at the conclusion of the inspection.

\section{Conflict of interest}

Article 105 of the FIEA requires an exchange (stock type) to establish a self-regulating committee (deemed by FIEA to have been delegated authority on decisions relating to self-regulation services) to be composed of three or more members with a majority of outside members. The chairperson of the Committee is to preside over the affairs of the Committee and is to be elected from the outside directors. The term of office of the members of the committee is one year with reelection for a maximum of four years. Alternatively, the FIEA allows an exchange to establish a separate SRO to handle its self-regulatory functions (citation). The TSE has chosen such approach, while the other exchanges have constituted self-regulating committees.

In the case of other SROs, the FIEA does not prescribe a specific structure for self-regulatory 


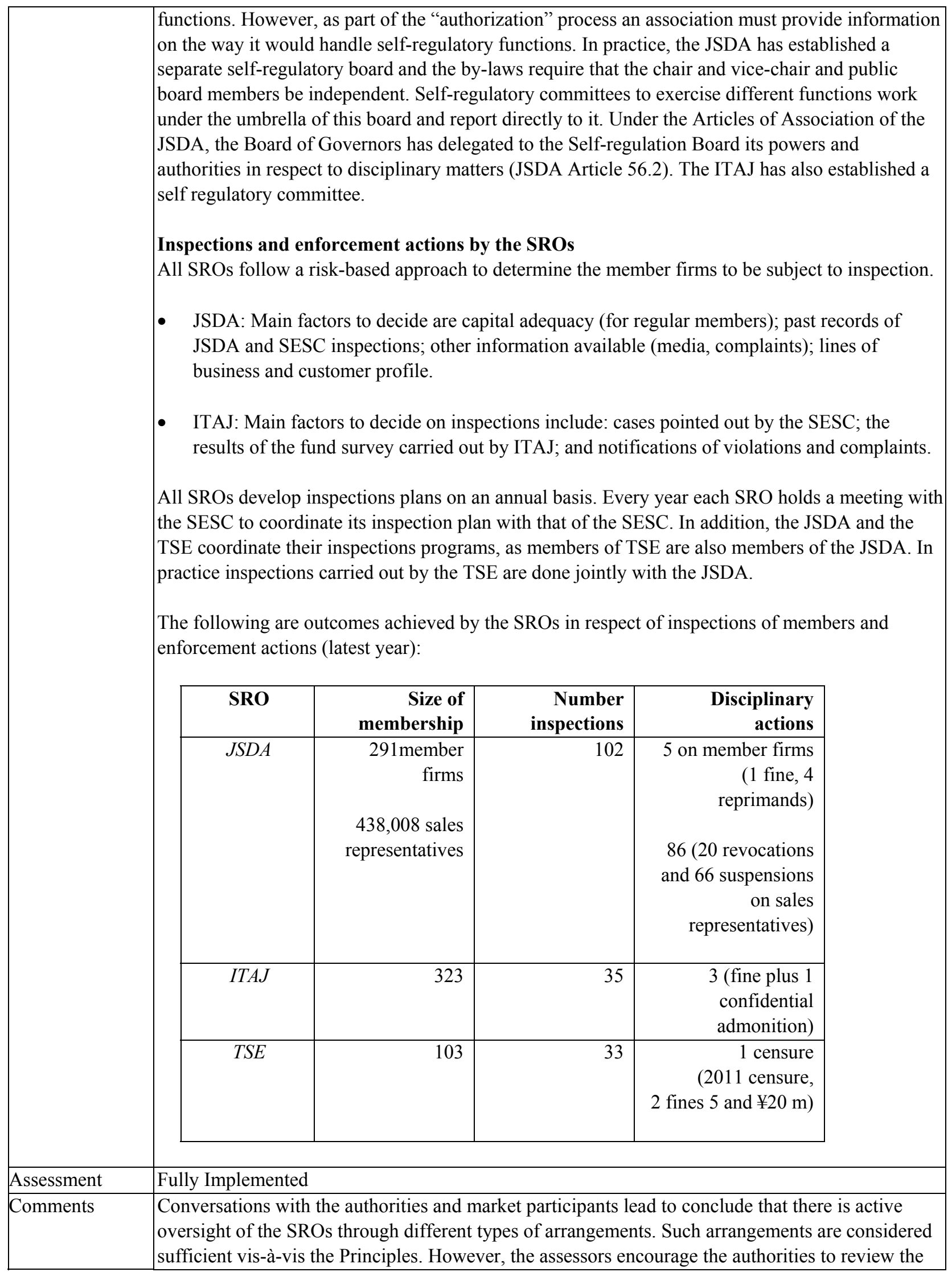




\begin{tabular}{|c|c|}
\hline & $\begin{array}{l}\text { inspection cycle for SROs. The assessors also encourage the authorities to continue to monitor the } \\
\text { way the SROs, in particular the JSDA and the ITAJ manage conflict of interests in the exercise of } \\
\text { their self-regulatory functions, and in particular in connection with the enforcement function. }\end{array}$ \\
\hline \multicolumn{2}{|r|}{ Principles for the Enforcement of Securities Regulation } \\
\hline Principle 10. & The regulator should have comprehensive inspection, investigation and surveillance powers. \\
\hline Description & $\begin{array}{l}\text { Powers over regulated entities } \\
\text { Article 56-2 in connection with Article 194-7 provides the FSA with broad supervisory powers } \\
\text { over regulated entities (FIBOs). In particular the FSA has the power to: } \\
\text { - Request reports and information (materials) from any FIBOs, as well as from the holding } \\
\text { company of a FIBO for the purposes of understanding the status of business or property of a } \\
\text { FIBO. } \\
\text { - Inspect the status of business or property of a FIBO, or the books and documents and other } \\
\text { articles of a FIBO, subsidiaries of a FIBO, or the holding company of a FIBO. The inspections } \\
\text { shall be limited to what is necessary to understand the property of a FIBO. The legal } \\
\text { framework allows for surprise inspections. } \\
\text { - Order a major shareholder of a FIBO (Type I or investment management) to submit reports or } \\
\text { materials, notifications under Article 32, or have the officials inspect documents or other } \\
\text { articles of the major shareholder. The inspections shall be limited to what is necessary to } \\
\text { understand the business of the FIBO. } \\
\text { The FIEA provides the FSA with broad powers over different types of SROs including the power } \\
\text { to: } \\
\text { - } \text { Order a parent financial institution, subsidiary financial institution of a FIBO to submit reports } \\
\text { or materials and have the officials of the FSA inspect the status of business or property, or the } \\
\text { books and documents or other articles. } \\
\text { Power over exchanges } \\
\text { Article } 151 \text { of FIEA provides the FSA with broad powers to: } \\
\text { - Order a Financial Instruments Exchange, its Subsidiary Company, an Issuer of Securities } \\
\text { listed in said Financial Instruments Exchange or a person to which the exchange has } \\
\text { outsourced services to submit reports or materials that will be helpful for understanding the } \\
\text { business or property of such Financial Instruments Exchange or its Subsidiary Company. } \\
\text { Have the officials inspect the status of the business or property, or the book and documents or } \\
\text { other articles of said Financial Instruments Exchange, Subsidiary Company or the person to } \\
\text { whom the exchange has outsourced services (with regard to said Subsidiary Company or such } \\
\text { person the inspection must be limited to what is necessary to understand the business or } \\
\text { property of the exchange). } \\
\text { ther Principle 9). }\end{array}$ \\
\hline
\end{tabular}




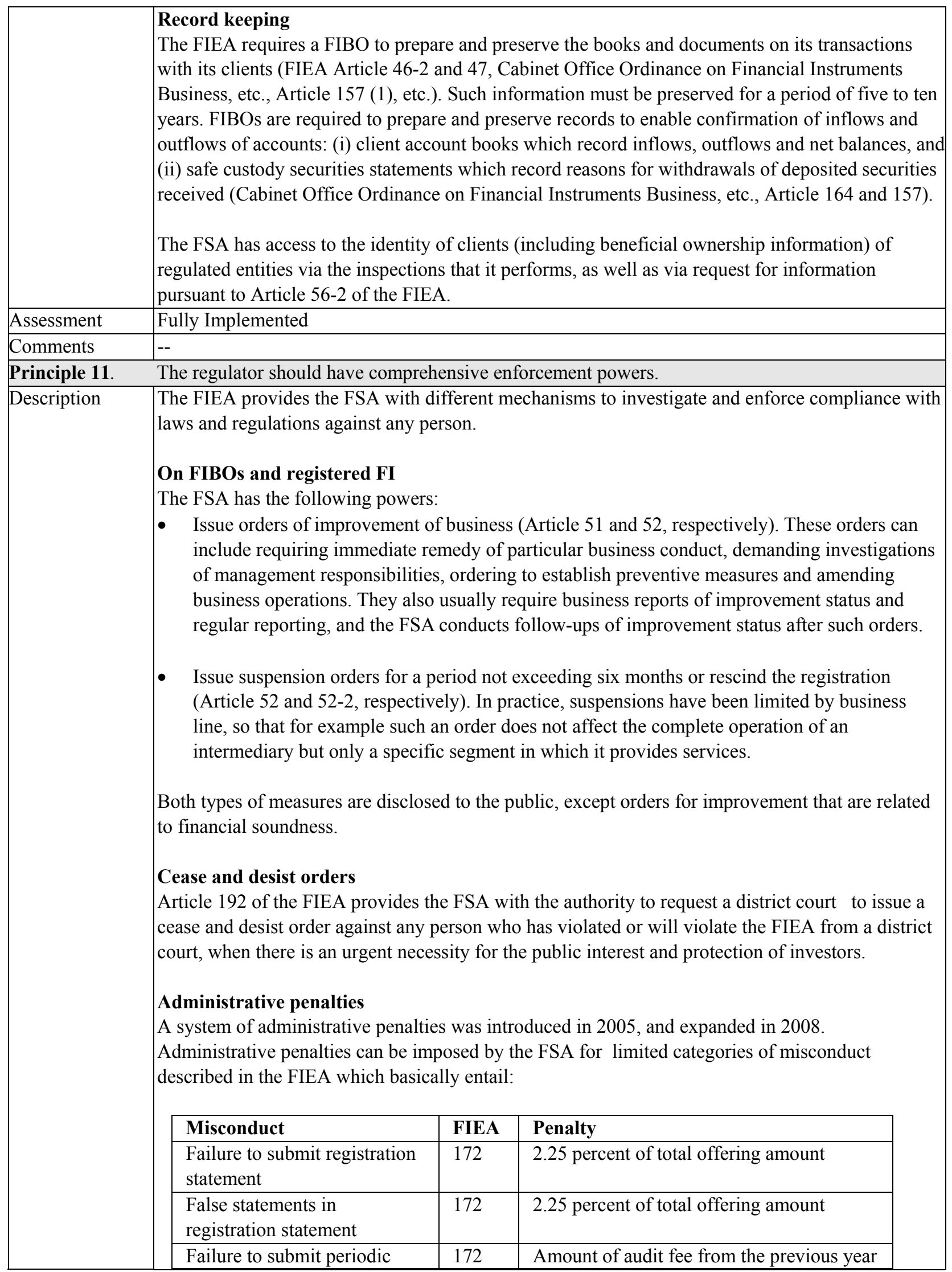




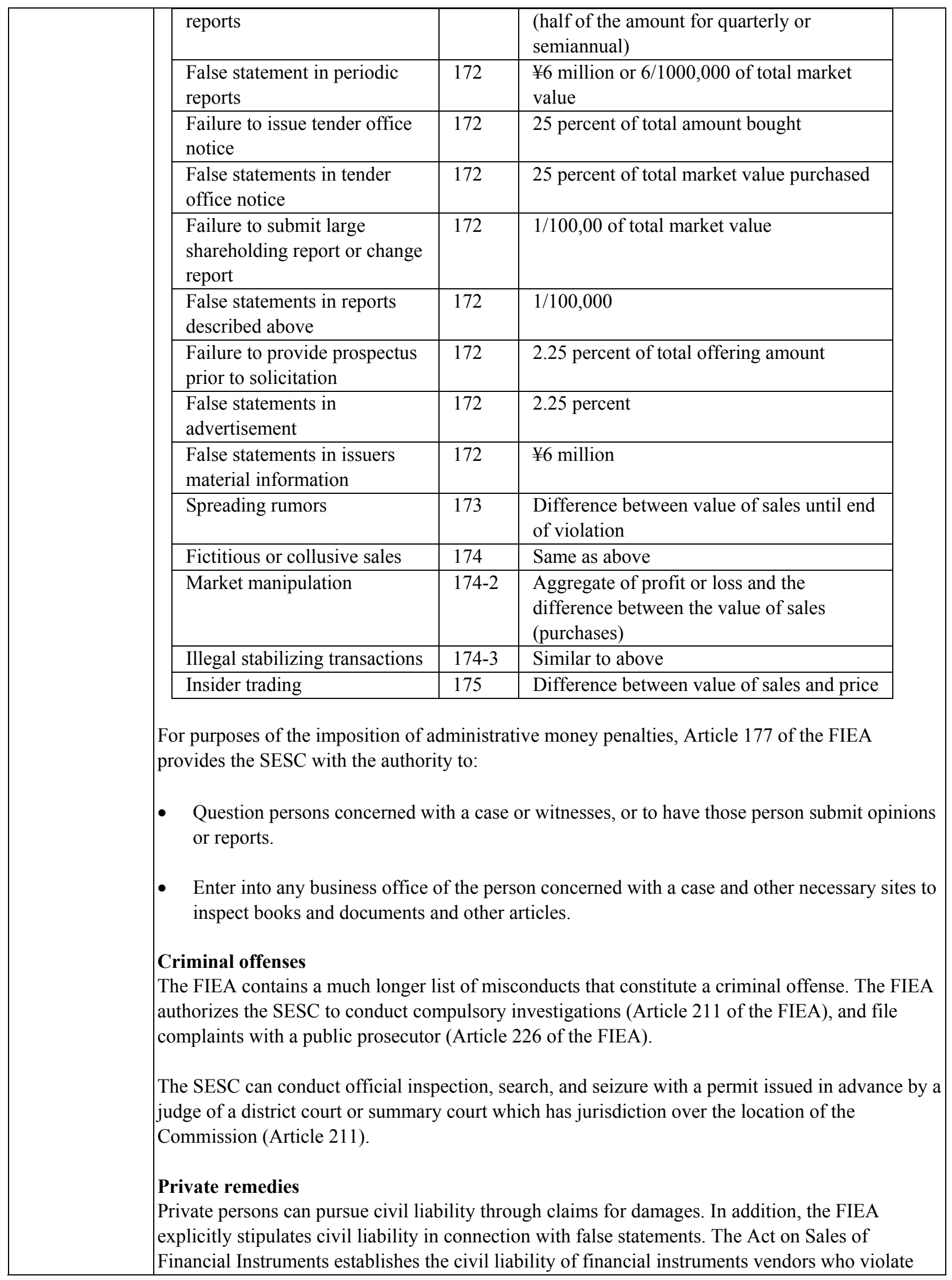




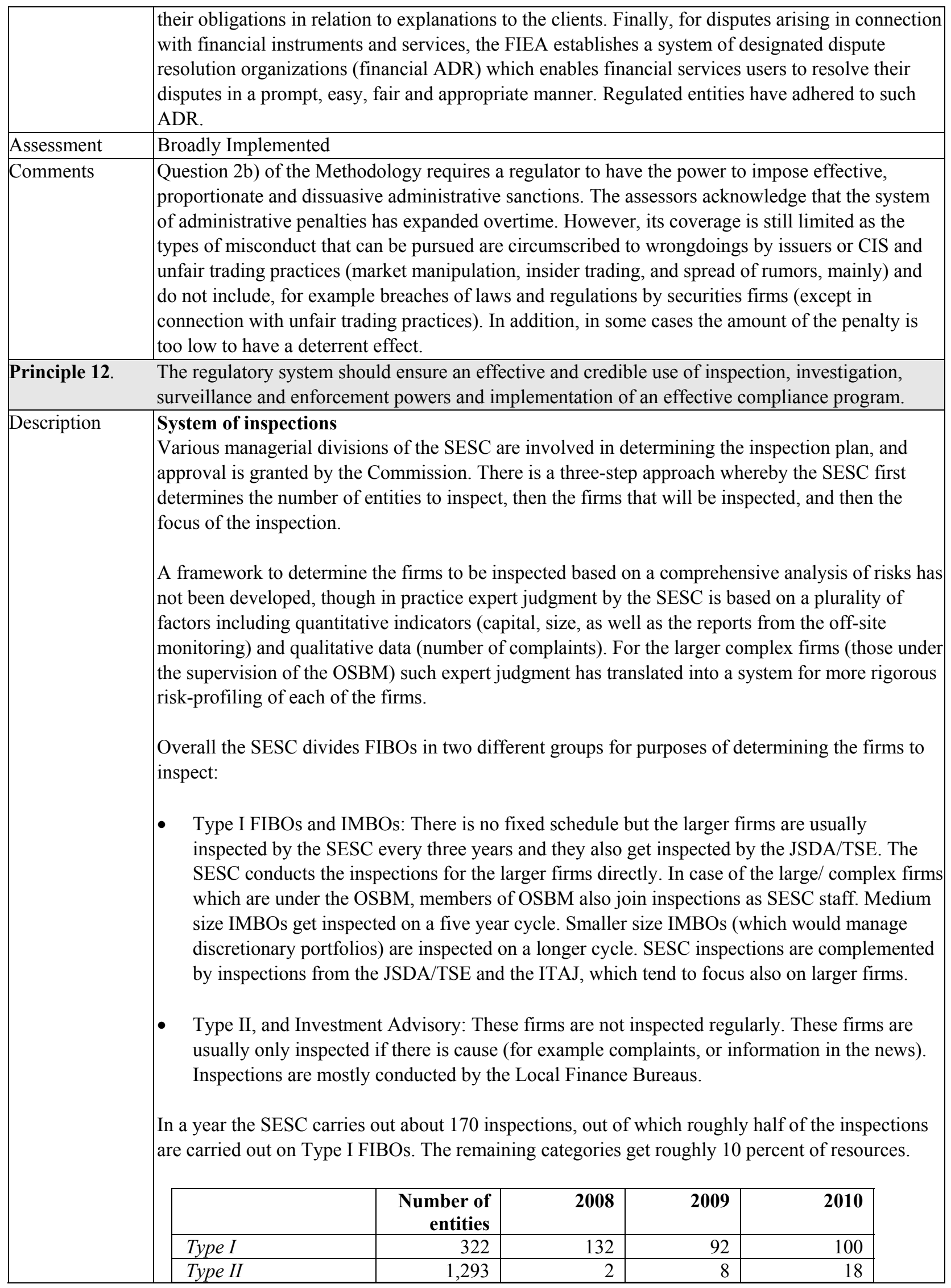




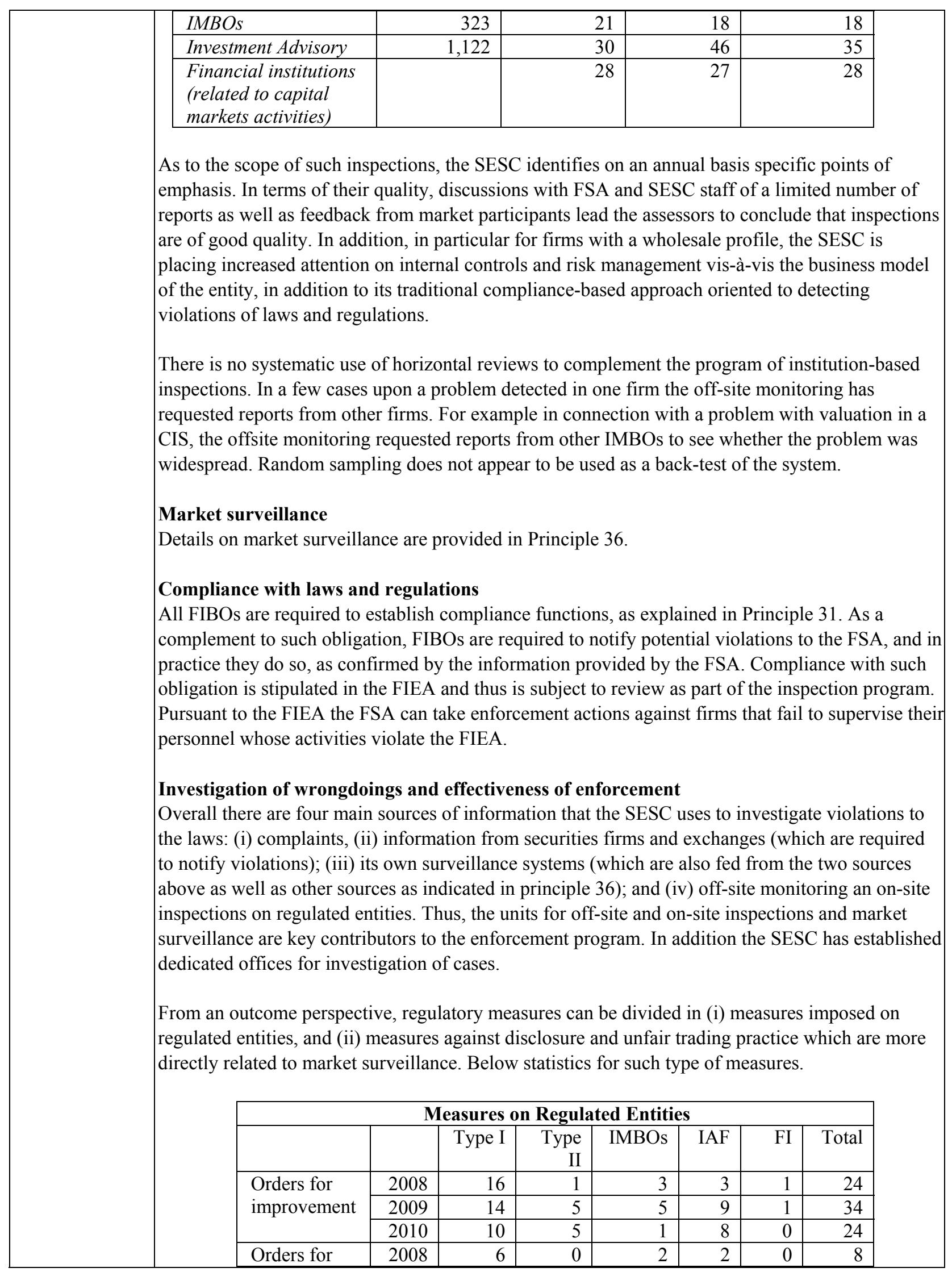




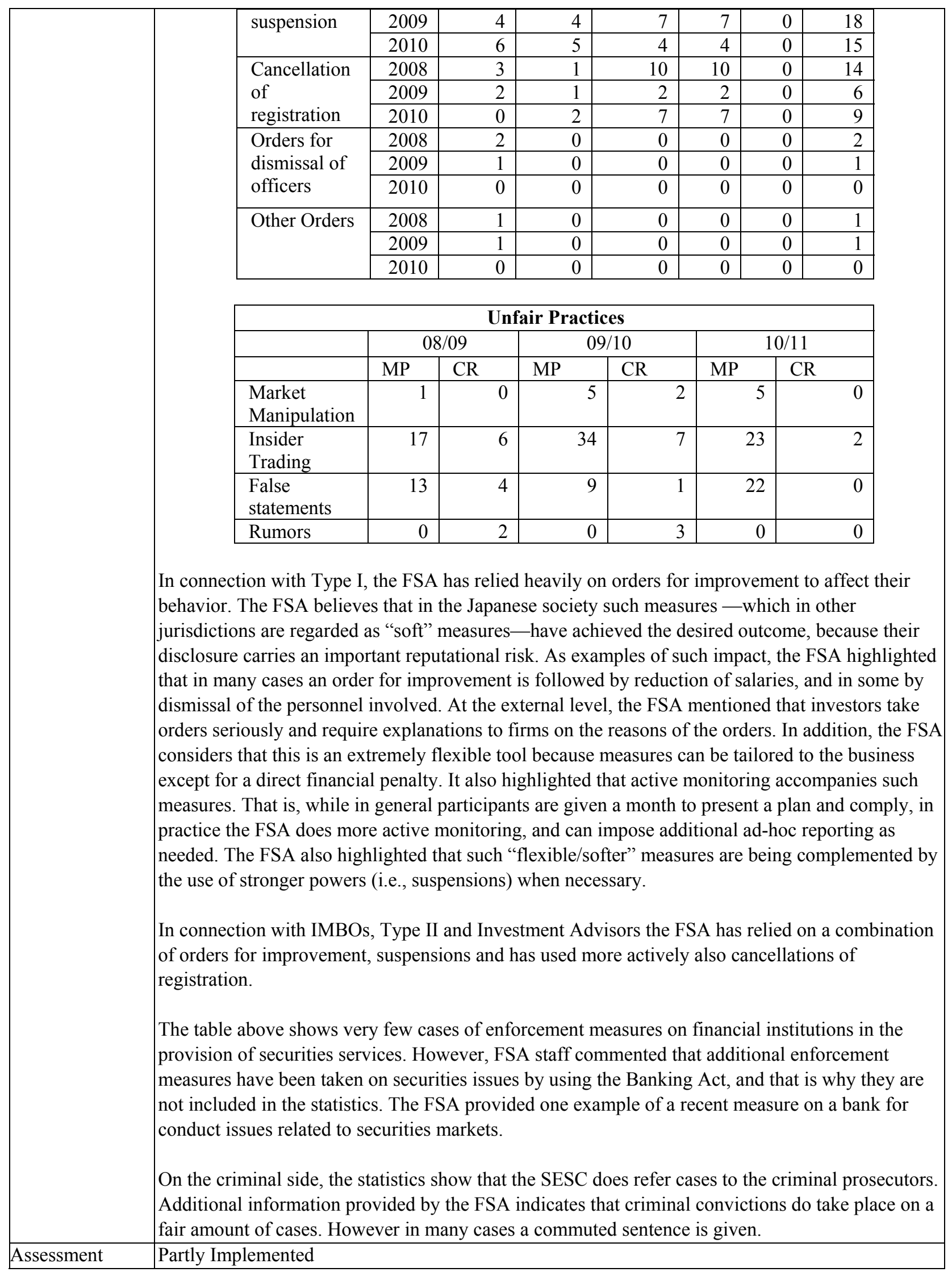




\begin{tabular}{|c|c|}
\hline Comments & 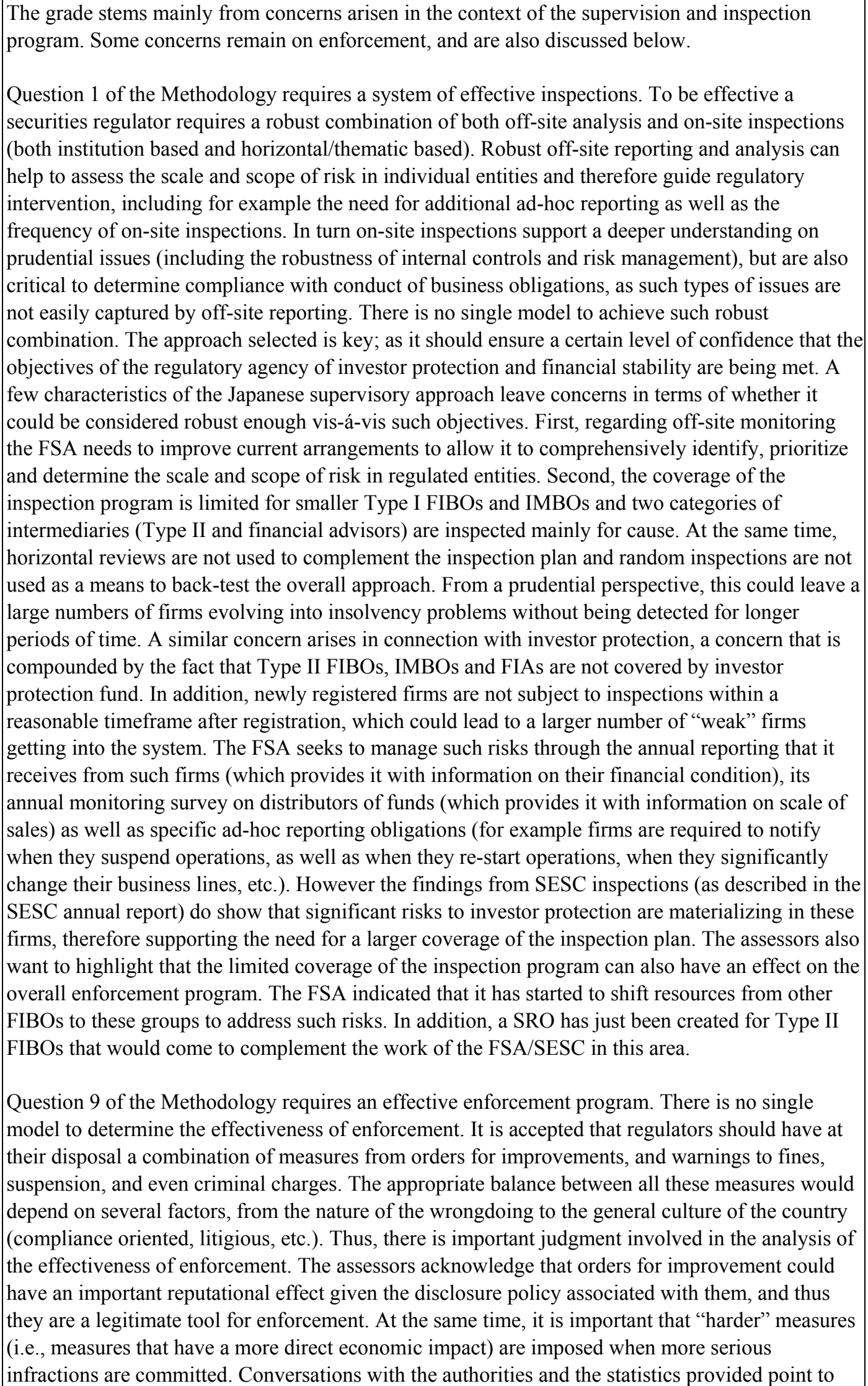 \\
\hline
\end{tabular}




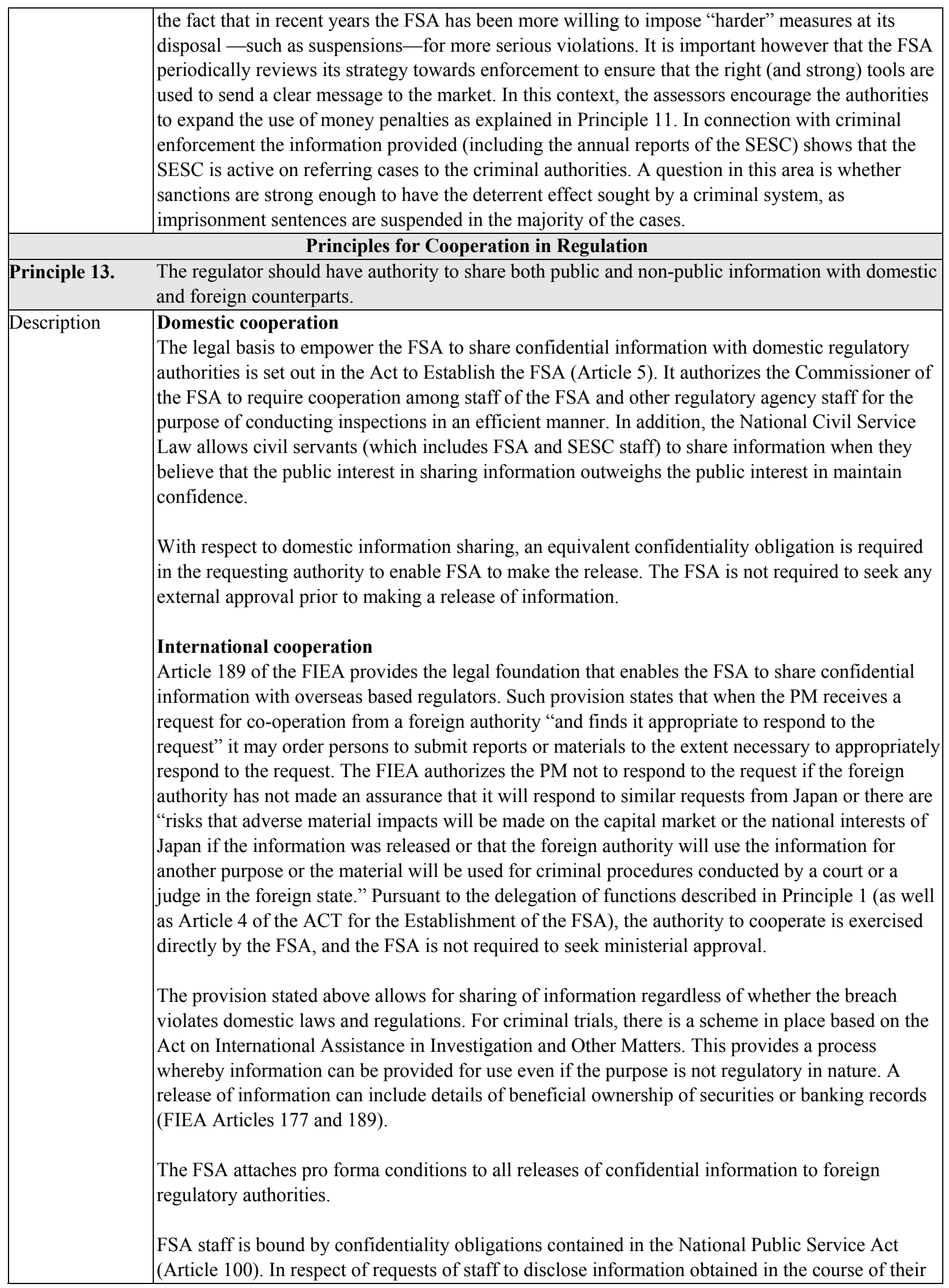




\begin{tabular}{|c|c|}
\hline & $\begin{array}{l}\text { duties to a parliamentary committee or to a civil or criminal procedure, prior consent from FSA or } \\
\text { relevant agency is required as specified in the relevant law. Information obtained by the FSA } \\
\text { pursuant to the IOSCO MMoU is kept confidential under the Information Disclosure Act. }\end{array}$ \\
\hline Assessment & Fully Implemented \\
\hline Comments & $\begin{array}{l}\text { Although the law provides the FSA with discretion to decide on requests for information from } \\
\text { foreign regulators, in practice the discretion has not been used to refuse requests. Furthermore } \\
\text { Japan has already signed the IOSCO MMoU which indicates that IOSCO consider FIEA's } \\
\text { provisions sufficient for international cooperation. }\end{array}$ \\
\hline Principle 14. & $\begin{array}{l}\text { Regulators should establish information sharing mechanisms that set out when and how they will } \\
\text { share both public and non-public information with their domestic and foreign counterparts. }\end{array}$ \\
\hline Description & 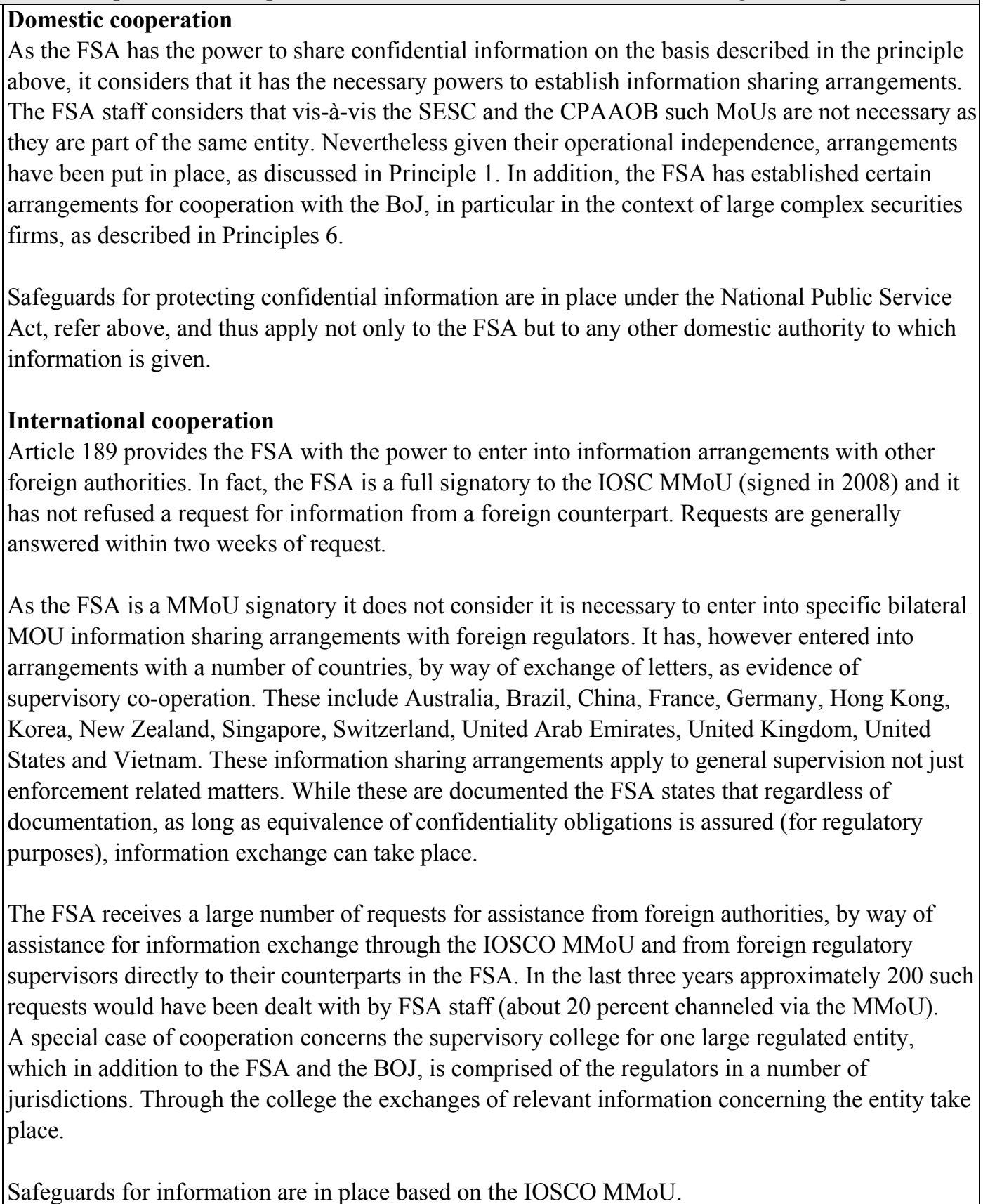 \\
\hline ssessment & \\
\hline
\end{tabular}




\begin{tabular}{|c|c|}
\hline Comments & $\mid--$ \\
\hline Principle 15. & $\begin{array}{l}\text { The regulatory system should allow for assistance to be provided to foreign regulators who need to } \\
\text { make inquiries in the discharge of their functions and exercise of their powers. }\end{array}$ \\
\hline Description & $\begin{array}{l}\text { Legal foundation } \\
\text { Article } 189 \text { of the FIEA provides the FSA with authority to give assistance to foreign regulators, } \\
\text { by collecting for them information or testimony that is not currently in its files. } \\
\text { The FSA believes that based on such provision it can (and is willing) to also provide assistance to } \\
\text { foreign regulators to obtain domestic court orders. As stated above, for criminal trials, there is a } \\
\text { scheme in place based on a mutual legal assistance treaty, pursuant to the Act on International } \\
\text { Assistance in Investigation and Other Matters. This provides a process whereby information can be } \\
\text { provided for use even if the purpose is not regulatory in nature. } \\
\text { Practice } \\
\text { As stated above, FSA is a signatory to the IOSC MMoU (signed in 2008) and it has not refused a } \\
\text { request for information from a foreign counterpart. Requests are generally answered within two } \\
\text { weeks of request. }\end{array}$ \\
\hline Assessment & Fully Implemented \\
\hline Comments & -- \\
\hline & Principles for Issuers \\
\hline Principle 16. & $\begin{array}{l}\text { There should be full, accurate and timely disclosure of financial results, risk and other information } \\
\text { that is material to investors' decisions. }\end{array}$ \\
\hline Description & $\begin{array}{l}\text { Public Offering of Securities } \\
\text { As per the FIEA a public offering or public selling of a security shall not be made unless the issuer } \\
\text { has notified and filed a securities registration statement with the FSA, when the total amount of the } \\
\text { public offering or public selling is ¥100 million (approximately US } \$ 1.275 \text { million) or over } \\
\text { (FIEA Article 4(1)). } \\
\text { Municipal securities are exempted from the public offering regime. FSA staff indicated that bonds } \\
\text { issued by the local governments are not officially guaranteed by the central government; however } \\
\text { an early warning system is in place to keep fiscal consolidation of local governments, whereby } \\
\text { local governments with deficits or debt payment ratios above a certain level must apply for } \\
\text { approval by the central government for bond or loan issuance. } \\
\text { According to Article } 5 \text { of the FIEA the securities registration statement must set out (i) matters } \\
\text { pertaining to the public offering or public selling, including terms and conditions of the security } \\
\text { and (ii) financial conditions of the group to which the issuer belongs and the issuer, other } \\
\text { important information concerning its business, and other information necessary and appropriate in } \\
\text { the public interest or for the protection of investors, including risk factors, segment information, } \\
\text { management discussion and analysis. The form of the registration statement is prescribed by } \\
\text { regulation passed under the FIEA. The basic information that such statement must contain is } \\
\text { summarized below: } \\
\text { Information concerning the securities: type, number, offer price and issue price, offering structure, } \\
\text { selling shareholders, subscription period, underwriters, total amount and use of proceeds } \\
\text { Information concerning the issuer and its corporate group: (i) an overview of the issuer’s (trends in } \\
\text { major business, history, nature of the business, affiliated companies, employees); (ii) issuer’s and } \\
\text { corporate group business (outline of results of operation, state of production, and sales; problems } \\
\text { to be resolved, risks, material contracts, research and development activities, analysis of their } \\
\text { financial conditions, operating results and cash flows); (iii) facilities of the issuer and group }\end{array}$ \\
\hline
\end{tabular}


(outline of capital investment, state of major facilities, etc.); (iv)information concerning the applicant (state of shares, dividend policy; trends in stock prices; directors and officers, corporate governance); (v) the issuer and its group financial conditions (financial statements, events subsequent to financial statements; differences in accounting principles if an issuer is a foreign company)

The FSA has the authority to request amendments (FIEA Article 9(1) and 10(1)). Accordingly, the notification made to the FSA comes into effect 15 days after the FSA has accepted the securities registration statement, or after the day of the submission of any amendment requested by the FSA (FIEA Article 8(1)). The FSA can also order the suspension of the effect of the notification if it finds that a securities registration statement contains false information that is material to investors, or lacks material information (FIEA Article 10). It also has the power to conduct on-site inspections on issuers under certain circumstances.

In addition a prospectus must be submitted to an investor before or on the moment that he/she acquires the securities (FIEA Article 15(2)). Overall such prospectus must contain the same information included in the securities registration statement (FIEA Article 15 (2)). In the case of an investment fund, a simplified prospectus must also be prepared (FIEA Article15 (2)).

\section{Periodic reports}

Annual

Issuers of securities which are (i) listed on a Financial Instruments Exchange (FIE), (ii) traded in the OTC market administered by the JSDA, or (iii) were publicly offered or publicly sold, are required to file an annual securities report with the FSA, within three months from the expiration of each business year (FIEA Article 24). Such report should include:

- The audited annual financial statements of the issuer and the group to which the issuer belongs and auditor's reports thereto; and

- Other important information concerning its business and other information necessary and appropriate in the public interest or for investor protection, including risk factors, segment information, management discussion and analysis. Thus, in addition to the financial statements the report discusses issues such as shareholders' information, corporate governance, and related party transactions.

In addition, any issuer which is required to submit the annual securities report and for which securities are listed on a securities exchange must submit a confirmation letter stating that the content of the annual report is in accordance with the FIEA (FIEA Article 24-4-2), and an internal control report which evaluates the framework for financial reporting of the issuer according to the FIEA and other relevant regulations (FIEA Article 24-4-4).

Semi annual

Any issuer which is required to file the annual securities report but not the quarterly securities report (for example an issuer of bonds which were offered to the public but are not listed) is required to file a semi-annual securities report with the FSA within three months after the expiration of a six-month period of its business year. Such report should include the financial conditions of the issuer and the group to which the issuer belongs, and other important information concerning its business. (FIEA Article 24-5 (1). Essentially such reports include the financial statements as well as any significant change from the annual report. 
Quarterly

Any issuer which is required to file the annual securities report and for which securities are listed on a securities exchange is also required to file with the FSA a quarterly securities report, within 45 days after the expiration of a three-month period of its business year. Such report should include the financial conditions of the issuer and the group to which the issuer belongs, and other important information concerning its business (FIEA Article 24-4-7 (1)). Essentially, the quarterly report is a summarized version of the annual report, where the emphasis is on the financial statements and any significant change from the previous report.

If the issuer has submitted a quarterly securities report or semiannual securities report, then in addition to the audited annual financial statements, the recent quarterly financial statements or interim financial statements are required to be included in the prospectus

Finally, the TSE also imposes on listed companies the obligation to submit a corporate governance report. The Corporate Governance Report requires information on topics such as major shareholders, number of employees, number and background of outside directors, name and background of auditors, remuneration of outside directors and operational support for outside directors, internal controls and structure of corporate governance.

\section{Material events}

An issuer required to submit an annual securities report (i.e., any issuer of a public offering) must submit to the FSA without delay an extraordinary securities report in the situations described below as well as if deemed necessary and appropriate for the public interest or protection of investors (Cabinet Office Ordinance on Disclosure of Corporate Affairs, Article 19 (1)):

- When a public offering or secondary distribution of securities issued by the issuer is made in a foreign country;

- When a private placement of securities is made in a foreign country or in Japan;

- Changes in the parent company or transfer of a major subsidiary of the issuer;

- Changes of major shareholders of the issuer;

- Major disasters or legal actions concerning the issuer; and

- Merger or other type of company reorganization.

In addition, the exchanges have established "the rule of timely disclosure" for listed companies. Under such rule, listed issuers are required to disseminate all corporate actions that can have a material impact on investors' decisions through the timely disclosure network (TDnet), the TSE online disclosure system. The exchanges have provided guidance as to the type of events that fall under the rule of timely disclosure. The exchanges have not provided additional guidance on what timely disclosure entails. The exchanges have established units that discuss beforehand material events with issuers, as a way to ensure that all information is complete.

\section{Shareholders decisions}

Listed companies are required to submit without delay an extraordinary securities report on items decided on at shareholders meetings. The report should include the results of the resolutions and number of votes for and against (Cabinet Office Ordinance on Disclosure of Corporate Affairs, 
etc., Article 19 (2) (ix)-2). In addition, a stock company is required to release minutes of the shareholder meetings, upon requests from the shareholders or debt holders (Companies Act Article 318, Ordinance for Companies Act, Article 72 (3) (ii)).

\section{Advertisement}

The FIEA stipulates that when advertisement is carried out through means different from the prospectus such means (whether in writing or in any other way) should not be misleading (FIEA Article $13(5))$.

\section{Availability of information to the public}

The FIEA requires the FSA to make the securities statements and the periodic reports available to the public for a fixed period of time (five years for registration documents, annual reports and internal controls reports; three years for quarterly and semiannual reports and shelf registration documents until expiration) (FIEA Article 25(1)). All these reports are submitted to EDINET via the Internet, and the general public can access them via the Internet.

In addition, all issuers which have filed with the FSA any of the reports mentioned above are required to maintain copies thereof at their principal offices and major branch offices and make them available to the public for a fixed period of time (FIEA Article 25 (2)).

Finally, all securities exchanges and securities dealers associations are required to maintain at their offices copies of the reports mentioned above and make them available to the public for a fixed period of time (FIEA Article 25 (3)).

\section{Mechanism to ensure compliance with disclosure obligations} Civil liability

The FSA establishes the obligation to compensate damages applicable to the issuer, the officers of the issuer, the auditors who audited the financial statements, the underwriters, as well as any person who has another person acquire securities using a prospectus that contains false information or lacks material information (FIEA Article 18-Article 21, Article 17).

Administrative penalty

As indicated in Principle 11, failure to submit disclosure documents or the inclusion of false statements on them is subject to administrative penalties.

\section{Criminal offenses}

A person who submits a securities registration statement that contains false information that is material to investors may be punished with imprisonment with work for not more than ten years or by a fine of not more than ten million yen, or both (FIEA Article 197 (1) (i)). The fine imposed on a juridical person cannot exceed $¥ 700$ million (FIEA Article 207 (1) (i)).

\section{Review of disclosure documents by the FSA/SESC}

Registration statements

The FSA has delegated the review of securities registration statements to the local finance bureaus. Prospectuses are not reviewed; however their content is in practice very similar to that of the registration statement; thus in practice their content is reviewed through the registration statement. All securities registration statements are subject to desk review before they become effective. The review by the local bureaus focuses on ensuring that the statement is complete; that is, that it includes information for each of the sections required by the FIEA and the Ordinance to it. In cases of complex products, by practice the local finance bureaus consult with the FSA. 


\section{Review of periodic information}

FSA

The FSA has also delegated the review of annual reports to the local finance bureaus. The local

finance bureaus review a sample of reports. The sample is selected based on a number of criteria:

- Issuers that hit certain quantitative limits/benchmarks;

- Issuers selected through random sampling; and

- Issuers audited by audit firms whose internal controls are not at an optimal level.

Once the sample is determined, the FSA looks at the quarterly and semiannual reports also. Based on the findings of such review the local finance bureaus may send questions to an issuer, to check the accuracy of information contained in the reports. If after the inquiries, non material errors are found the issuers are required to submit a voluntary revision of the report. When the bureaus consider that there are material inaccuracies, they send a report to the SESC.

This screening is done twice a year.

SESC

The SESC also conducts a review of issuers' periodic information based on various previously established criteria (including certain quantitative thresholds) and information coming from different sources. .Over the past three years, there were 44 cases of decisions of an order to pay an administrative monetary penalty concerning false statements in disclosure documents

\section{Derogations of full disclosure}

Pursuant to the FIEA an issuer can request to the FSA that information included in its registration statement or periodic reports not be made available to the public on the grounds of being a business secret (FIEA Article 25 (4)). In deciding on the approval, the FSA comprehensively considers the nature of the items vis-à-vis investor protection (Disclosure Guidelines, 252). For such an approval, the FSA seeks the submission of written opinions from related persons, such as the audit firm, or refers to the opinion of the Financial Instruments Exchange where the issuer is listed, as needed. The FSA informed that these types of requests are very rare.

\section{Suspension of trading}

If information about securities or their issuer is deemed to possibly have major effects on investment decisions, and if the content of that information is unclear, or if the exchange deems that investors must be fully informed about the content of that information, then the Financial Instruments Exchange can suspend trading on such securities (Operating Rule of the Tokyo Stock Exchange, Article 29 (ii)).

\section{Insider trading}

Insiders, such as officers, employees and shareholders, who have come to know material information pertaining to the business or other matters of a listed company, are prohibited from trading their securities before disclosure. A person who has received such material information from such an insider is also prohibited from trading the securities he/she holds before disclosure.

Finally if a listed company's officers, employees, major shareholders make certain transactions such as purchase of securities, reports on such transactions must be submitted to the FSA. Also, if a listed company's officers, employees, major shareholders sold securities and obtained profits within six months after purchase, then the listed company can demand that they return those 


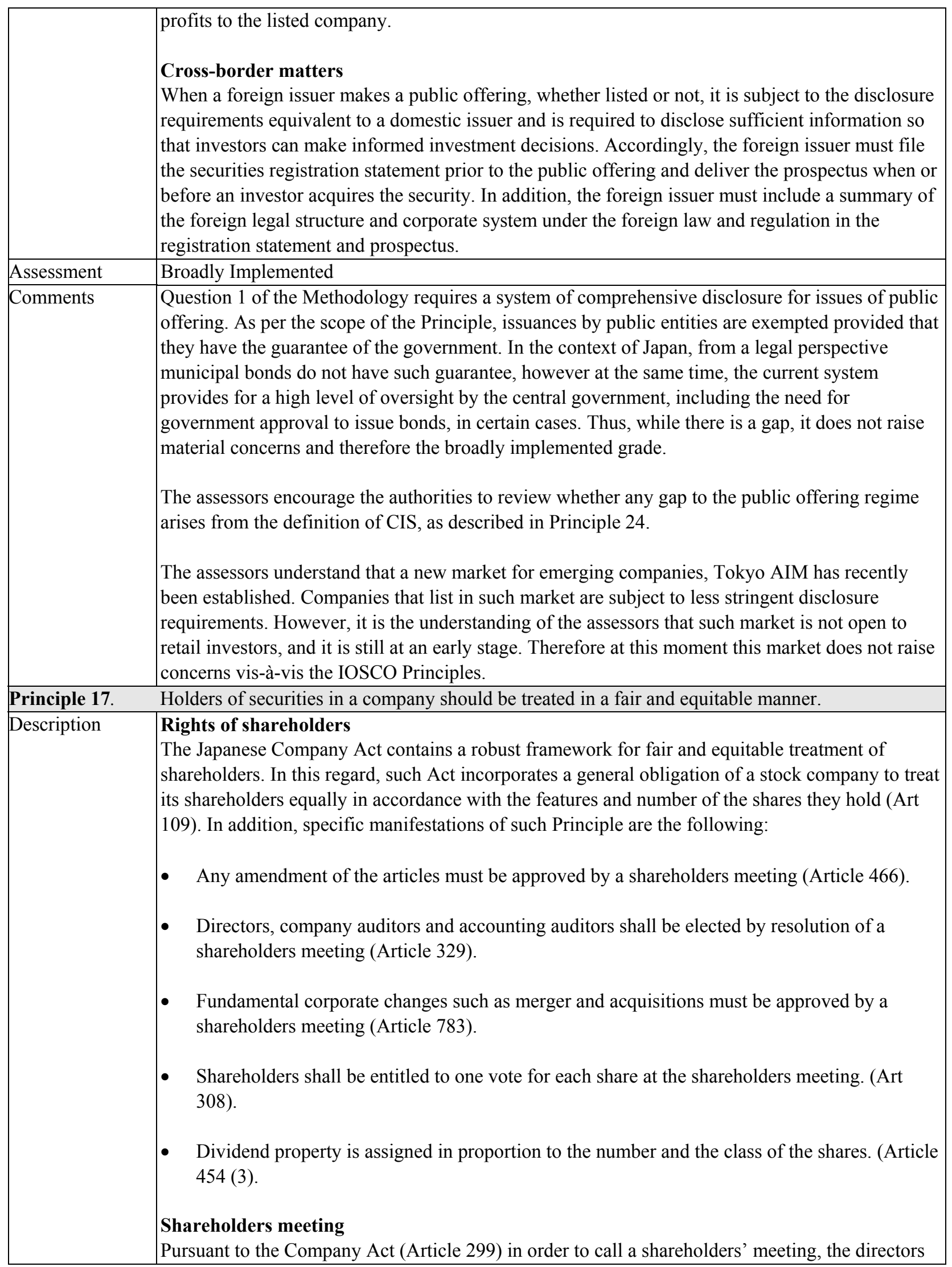


must send a notice to shareholders no later than two weeks before the meeting takes place. In cases where voting in writing is allowed, the reference document for shareholders' meeting and the voting form should also be sent (Article 301). The Company Act allows proxy votes and stipulates that, if the number of shareholders' is one thousand or more, voting in writing needs to be allowed (Company Act, Article 298 (2)).

\section{Tender offer}

The FIEA requires a mandatory tender offer in cases where after an off-the-markets purchase of shares the holding ratio of the acquirer would exceed one-third of the shares of the company (Article 27-2). The FIEA also requires a mandatory tender offer in cases where after an off-the-markets purchase of shares from a large number of people (i.e., over 10 people in 60 days) the holding ratio of the acquirer would exceed five percent of the shares of the company

The FIEA allows for partial offers, and in such case if the number of shares offered exceeds the number planned to be purchased in the offer, then the acquisition must be on a pro rata basis. However, when the holding ratio would be two-thirds or more after purchase, then the acquirer is required to make an offer to buy all the shares which are offered for sale.

The FIEA requires disclosure to the shareholders of the conditions of the offer on the start date of the tender offer. The offering document must include information on the purpose of the tender offer, grounds for valuation of the offer price, process of valuation of the offer price, and target company's opinion on the tender offer. In general, an independent valuation is not required. However, in the case of MBO if the acquirer obtains an independent valuation report, the acquirer must submit it to the Kanto Local Finance Bureau.

The period for the offer must be at least 20 business days, and at most 60 business days (FIEA Article 27-2 (2) and Order for Enforcement of the FIEA Article 8 (1)).

The FIEA Article 27-2 stipulates that the purchase price shall be equal for all shareholders who offer the sale of tendered shares.

The FSA has delegated the review of the offering documents for a tender offer in the Kanto local finance bureau. A practice has developed whereby an acquirer informally consults the offer document with the bureau. Through such informal process the bureau raised any concern that they might have. As a result when the offering document is submitted the bureau rarely has to request changes - usually only if changes in the company have occurred since the informal consultation. There are roughly $60-80$ tender offers a year in Japan in recent years.

\section{Other change of control transactions}

Changes of control by means of a merger require shareholder approval. In addition to the notice required for all shareholders meetings, the Company Act requires that stock companies keep documents or electromagnetic records that state or record the contents of the merger agreement at its head office at least two weeks before the shareholders' meeting (Article 782). Consideration for a merger should be delivered in proportion to the number of the shares of each class.

\section{Bankruptcy or insolvency of the company}

While shareholders are not able to participate in the process of bankruptcies and civil rehabilitation, they can participate in the process of corporate reorganization (the Corporate Reorganization Act, Article 165 (1)). In the process, the reorganization plan should treat the shareholders equally (the Corporate Reorganization Act, Article 168 (1) (v) and (vi)). 


\section{Accountability of directors and senior management}

Article 314 of the Company Act stipulates that in cases where a director, an accounting advisor, a company auditor or an executive officer is requested by the shareholders to provide explanations on certain matters at the shareholders meeting, they shall provide necessary explanations at the meeting.

In addition, Article 423 of the Company Act established that directors, accounting advisor, company auditor, executive officer or accounting auditor that neglects their duties shall be liable to the Company for damages arising as a result thereof.

\section{Substantial holdings}

Disclosure in offering documents

The securities registration statement and prospectus must contain the "Status of Major Shareholders" for the top 10 shareholders listed in descending order by their numbers of shares held, showing: names, addresses, numbers of shares held, and percentages of their numbers of shares held compared to the total number of issued shares (Cabinet Office Ordinance on Disclosure of Corporate Affairs, Template 2). The same applies to the semiannual and quarterly securities reports (Cabinet Office Ordinance on Disclosure of Corporate Affairs,

Template 4-3 and 5). For disclosure documents, if a change occurred in important facts, then an amendment or amendment report must be submitted (FIEA Article 7 and 24-2).

\section{Other extraordinary reports}

In the case of issuers who must submit an annual report (all issuers of public offering), if there are changes in the major shareholders who hold 10 percent or more of the voting rights, then the issuer must submit without delay an extraordinary securities report which contains the names of major shareholders, numbers of voting rights of major shareholders and their percentages of the voting rights of all shareholders before and after the change, and the date of the change (Cabinet Office Ordinance on Disclosure of Corporate Affairs, etc., Article 19 (1) (iv)).

Finally, the FIEA requires a person who comes to hold over five percent of the shares of a listed company to submit a Report of Possession of Large Volume within five business days. In addition, when there is a change of one percent or more in the holding ratio, a Change Report shall be submitted also within five business days. The FIEA stipulates that when there are joint holders, their held shares are aggregated for the purposes of determining whether they are required to submit a Report of Possession of Large Volume (Article 27-23 and 27-25).

\section{Insider holdings}

The number of shares held by officers must be included in the company's disclosure documents, such as the securities registration statements (Cabinet Office Ordinance on Disclosure of Corporate Affairs, etc., Template 2), the annual securities reports (Cabinet Office Ordinance on Disclosure of Corporate Affairs, etc., Template 3), the quarterly securities reports (Cabinet Office Ordinance on Disclosure of Corporate Affairs, etc., Template 4-3) and the semiannual securities reports (Cabinet Office Ordinance on Disclosure of Corporate Affairs, etc., Template 5).

In addition, if an officer meets the criteria for substantial holdings stated above, he/she must submit the relevant reports.

Public availability

All disclosure documents and reports must be submitted via EDINET, and therefore are available to the public. 


\begin{tabular}{|c|c|}
\hline & $\begin{array}{l}\text { Compliance with obligation to disclose shareholdings } \\
\text { Staff informed that there are no major violations of these obligations, though in a few cases late } \\
\text { filing has occurred. }\end{array}$ \\
\hline Assessment & Broadly Implemented \\
\hline Comments & $\begin{array}{l}\text { Question 5a) of the Methodology requires timely disclosure to the public of transactions carried } \\
\text { out by insiders. In the case of Japan insiders are not subject to notification requirements; rather } \\
\text { their holdings must only be disclosed in the registration documents. In the opinion of the assessors } \\
\text { such approach to disclosure does not guarantee timely information to investors as required by the } \\
\text { principles. It is important to acknowledge however that if their holdings become substantial, then } \\
\text { they are subject to the notifications pertaining substantial holdings as described also in this } \\
\text { principle. } \\
\text { In connection with Question } 3 \text { of the Methodology, the assessors also recommend that the } \\
\text { authorities review the provisions for mandatory tender offers, to determine whether they should be } \\
\text { extended to on-the market purchases. The assessors also encourage a review of squeeze-out } \\
\text { provisions. These issues have not been taken into consideration for the grade. }\end{array}$ \\
\hline Principle 18. & $\begin{array}{l}\text { Accounting standards used by issuers to prepare financial statements should be of a high and } \\
\text { internationally acceptable quality. }\end{array}$ \\
\hline Description & $\begin{array}{l}\text { Obligation to audit statements } \\
\text { Pursuant to the Cabinet Office Ordinance on Disclosure of Corporate Affairs the securities } \\
\text { registration statement and the annual securities report that issuers are required to submit must } \\
\text { contain financial statements (Article } 8 \text { and 15). The FIEA requires that such statements be audited } \\
\text { by an independent CPA or audit firm (Article 193-2, Order for Enforcement of FIEA and Article } \\
35 \text { and Cabinet Office Ordinance on Audit Certification of Financial Statements). } \\
\text { Where unaudited financial statements are used, for example, in interim reports, and interim period } \\
\text { financial statements in public offering and listing documents, in full or summary format, an audit } \\
\text { certification or review is required for such interim financial statements and quarterly financial } \\
\text { statements (Cabinet Office Ordinance on Audit Certification of Financial Statements, etc., Article } \\
\text { 1). } \\
\text { Content } \\
\text { As per the FIEA the financial statements must include: balance sheet, profit and loss statement, } \\
\text { cash flow statement, and a statement of changes in stockholder equity (Article. 193 of FIEA the } \\
\text { Ordinance on Terminology, Forms and Preparation Methods of Financial Statements, etc. Article } 1 \\
\text { (1) and the Cabinet Office Ordinance on Disclosure of Corporate Affairs, etc., Template } 2 \text { and } 3 \text {, } \\
\text { etc.). } \\
\text { The preparation of financial statements must comply with the following principles stated in the } \\
\text { Ordinance on Terminology, Forms, and Preparation Methods of Financial Statements (Article 5): } \\
\text { - Show true content on the financial status, business results and cash flow status of the company } \\
\text { submitting financial statements } \\
\text { - Clearly show accounting facts required to avoid mistaken judgment by interested parties } \\
\text { regarding the status of finances, business and cash flow of the company submitting the } \\
\text { financial statements } \\
\text { - The same principles and procedures of accounting treatments should be used through each } \\
\text { period for which financial statements are submitted, except if changed for proper reasons. } \\
\text { For items with the same content, the same presentation methods must be adopted through each } \\
\text { Financial statements are required to contain information in comparison with the financial }\end{array}$ \\
\hline
\end{tabular}


statements of the previous period

\section{Accounting standards used}

The FIEA requires that financial statements be prepared in accordance with generally accepted accounting standards published by the Business Accounting Council and the Accounting Standards Board of Japan (ASBJ) (Article 193 and Article 1 of the Ordinance on Terminology, Forms and Preparation Methods of Financial Statements). In practice, since the establishment of the ASBJ in 2001, the responsibility for developing accounting standards lies in the ASBJ.

The ASBJ has implemented a public comment procedure for the development of accounting standards. Once a standard has been finalized and published by the ASBJ, it needs to be endorsed by the FSA (through the Commissioner) (Article 1(3) of the Ordinance on Terminology, Forms and Preparation Methods of Financial Statements). The ASBJ's discussions on accounting standards and accounting standards implementation guidance are open to the public, with the FSA participating as an observer without any voting rights. On practical issues, the ASBJ reflects the revisions of accounting standards and publishes practical response reports.

Under the Ordinance on Terminology Forms and Preparation Methods of Financial Statements, etc., Article 1 (3), the ASBJ must:

- Be a private organization independent from persons who have interests;

- Continually receive funds provided from many people, not biased towards specific persons;

- Be an institution with a council system, established by people who have the ability to create company accounting standards from highly specialized viewpoints; and

- Continually consider, from the viewpoints of the business environment faced by companies, appropriate responses to changes in company practices, and international convergence.

\section{Quality of the standards}

As a result of the implementation of a project towards convergence with IFRS, there are currently no major differences between Japanese GAAPs and IFRS. The only difference remaining is on development cost, but the ASBJ is currently discussing how to converge with IFRS on this issue. In addition, as per a Protocol between the ASBJ and the IAISB the ASBJ is to consider mandatory adoption of IFRS by 2012.

\section{Oversight of accounting standards development}

The ASBJ is overseen by the Financial Accounting Standards Foundation, which is established as a public interest incorporated foundation in accordance with the Act on Authorization of Public Interest Incorporated Associations and Public Interest Incorporated Foundation (Article 27). The foundation is subject to reporting, inspections, recommendations, and orders by the FSA.

\section{Enforcement of accounting standards}

The auditing of financial statements by registered auditors constitutes a key mechanism to ensure compliance by issuers with accounting standards. In turn, the FSA has developed a system to oversee auditors' quality, as will be explained under Principle 19. In addition, as explained under Principle 16, both the FSA (through the local bureaus) and the SESC conduct reviews of disclosure documents.

If deficiencies or false statements are found in such reports (which can relate to the financial statements) the FSA has the authority to request the issuer to submit an amendment or amendment report (Article 9, and 10 respectively of the FIEA). 


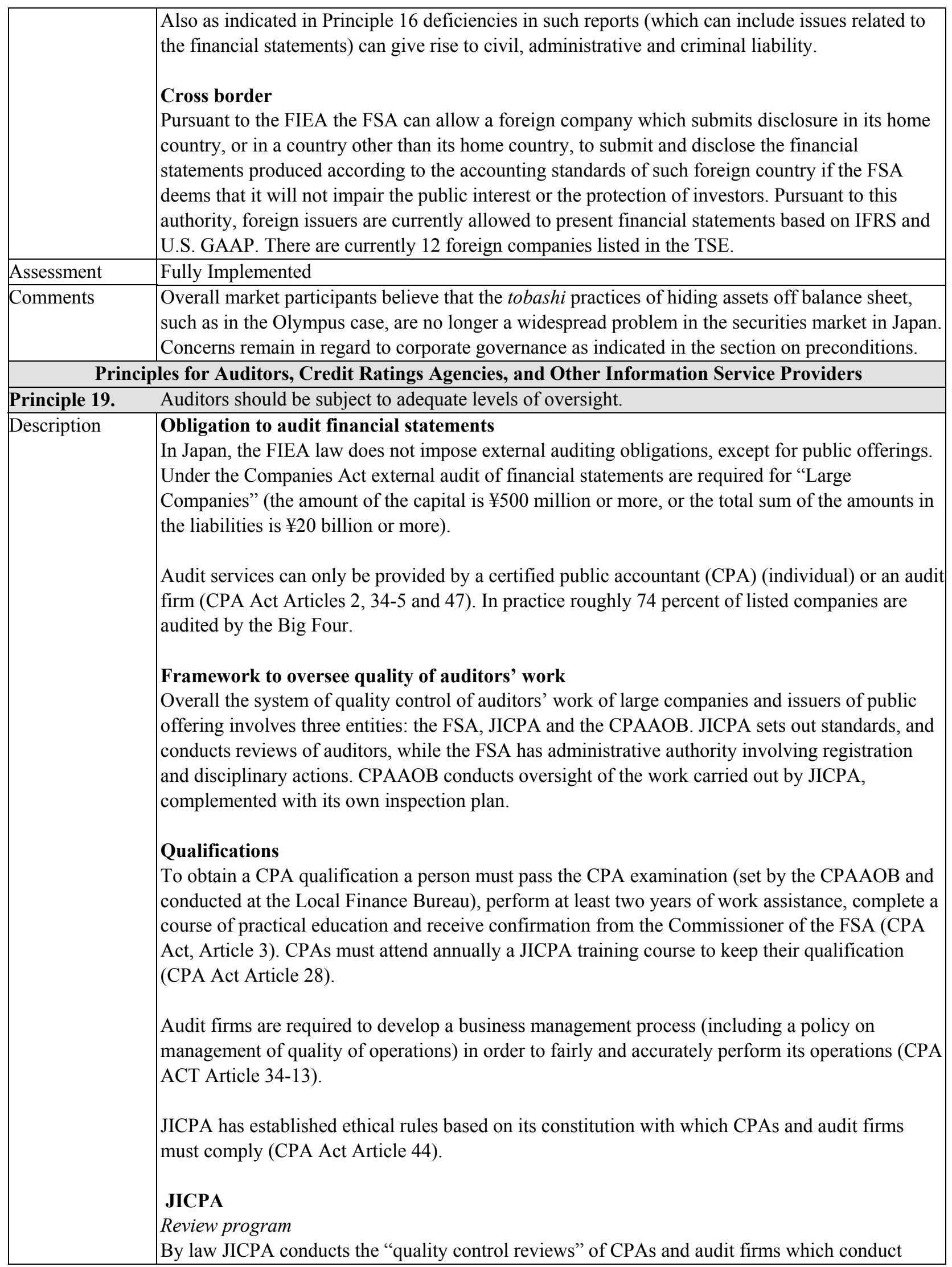


external audits of the financial statements of entities prescribed in JICPA's constitution, including "Large Companies" (except where the amount of the capital is less than $¥ 10$ billion and the total sum of the amounts in the liabilities is less than $¥ 100$ billion) and companies that offer securities to the public. Auditors are registered specifically for such audits by JICPA by its Quality Control Committee.

JICPA has a panel of 27 reviewers for its review program. JICPA has required 10 years of auditing experience for its reviewers. Market participants commented that some of them are hired for fixed periods and then go back to the industry.

Reviews are conducted on a three year cycle but in the case of the big four audit firms, JICPA's aim is a cycle of two years. Results of such reviews are reported to the CPAAOB (CPA Act Article 46-9-2). Reporting is done on a monthly basis, and there is also an annual report on JICPA's functions.

In fiscal year 2010, JICPA performed 99 quality control reviews of audit firms (53 audit corporations (including 1 joint audit office) and 46 CPAs). By March 31, 2011, 81 reports on those quality control reviews were submitted to the CPAAOB. Seventy nine out of the 81 cases reported to the CPAAOB included recommendations to remedy deficiencies. The conclusions of those reports were as follows:

- Unqualified conclusion: 77 cases (40 audit firms and $37 \mathrm{CPAs}$ ).

- Qualified conclusion: 4 cases (1 audit firm and 3 CPAs).

- Negative conclusion (none).

Market participants interviewed considered the quality of JICPA reviews to be thorough.

Enforcement actions

The JICPA has the authority to suspend membership but cannot fine them for misconduct. In addition it can refer a case to the FSA so that FSA can take appropriate measures pursuant to the CPA Act. In practice JICPA has used recommendations for improvement of quality control when it has found deficiencies, and has requested a remediation plan. If remediation is not satisfactorily implemented, JICPA has implemented a list of "unsatisfactory" auditors, which has the effect of preventing them from being used for audits of public issuers. JICPA has used such power. For example, in June 2010, two firms were placed on the list and subsequently ceased business.

\section{CPAAOB oversight}

Powers

Pursuant to the CPA Act the CPAAOB has the power to:

- Request JICPA to submit reports or materials on its operations, including procedures for quality control review.

- Conduct an on-site inspection on JICPA where it considers it necessary.

- Conduct inspections on audit firms (CPA Act Article 49-3(2)).

- Make a recommendation to the Commissioner of the FSA concerning administrative or other action in respect of JICPA (CPA Act Article 41-2). 
- Make recommendations for administrative actions in connection with auditing firms (the law provides that the Commissioner of the FSA must consult with CPAAOB and ask for its opinion about any penalty after FSA has held a hearing except where disciplinary action is based on such recommendation).

Inspection program

In practice the CPAAOB relies on the work carried out by JICPA, but complements it with a few inspections of its own. On an annual basis, the CPPAOB states the focus of its annual inspection plan. For 2010, its focus was quality control systems of audit firms and enhancing the function of quality control reviews by JICPA. In addition such plan states that the CPAAOB will conduct its own inspections with respect to the large audit firms and non large audit firms that have a relatively large number of listed companies as their audit clients.

In fiscal year 2009, the CPAAOB examined quality control reviews performed by the JICPA during the fiscal years of 2008 and 2009. The objective of such examination was to ascertain the following points:

- Appropriateness of JICPA's quality control reviews.

- Status of development and operation of quality control systems established for ensuring the quality of audit services.

- Implementation of quality control by each audit firm in relation to the performance of respective engagement.

As a result of such examination, pursuant to its Basic Plan on Examination and Inspection, the CPAAOB also has performed nine inspections of auditing firms. Inspection findings have been given to the firms for self implementation and one case was referred to the FSA for administrative action, for insufficient operational control.

\section{Enforcement}

The FSA has a broad array of tools at its disposal regarding auditors. It may:

- Issue a reprimand or an order for business improvement.

- Order a disposition (admonition or business suspension) if a CPA or audit firm made a false or improper certification, violated the CPA Act or conducted improper business operations.

- Cancel the registration (deregistration as a disciplinary measure).

- Suspend a firm from conducting business for a maximum of two years.

- Starting in 2008 administrative monetary penalties can also be imposed (however to date this new measure has not be used).

- A fine of not more than $¥ 1$ million can be imposed under CPA Act Article 53 where there was a failure to submit a report or materials or for the avoidance or obstruction of an on-site inspection.

- Finally criminal charges could be filed (for falsifying audit reports of public issuers), and the 


\begin{tabular}{|c|c|}
\hline & $\begin{array}{l}\text { sanction for a criminal violation may be imprisonment (with work for not more than } 10 \text { years) } \\
\text { or fine up to ¥10 million or both (FIEA Article 197). } \\
\text { In practice, the CPAAOB has issued recommendations s for improvement to JICPA quality control } \\
\text { review, for example requesting it to increase the number of reviewers. In the case of auditing } \\
\text { firms, when the CPAAOB started its operation, it disclosed publicly the findings of its initial } \\
\text { inspections on the "big 4" audit firms. Later on it has adopted the practice to issue reports that } \\
\text { state the main findings of its inspections. Every year since 2008, the CPAAOB has published and } \\
\text { made available on its web site a "Case Report on Deficiencies in Audit Quality Control." The FSA } \\
\text { has issued administrative actions in all cases where the CPAAOB makes recommendation for } \\
\text { administrative action ( } 15 \text { cases). }\end{array}$ \\
\hline & Fully Implemented \\
\hline Comments & $\begin{array}{l}\text { Question } 6 \text { of the Methodology requires an oversight process that is independent from the audit } \\
\text { profession. Based on conversations with market participants the assessors conclude that the } \\
\text { CPAAOB has actively overseen JICPA, as demonstrated by the recommendations to JICPA to } \\
\text { increase resources. Measures have been taken by both JICPA and the FSA on auditors. The } \\
\text { assessors encourage the authorities to continue strengthening the system. In this context the review } \\
\text { announced by the FSA, in light of the Olympus incident, is welcome. }\end{array}$ \\
\hline Principle 20. & Auditors should be independent of the issuing entity that they audit. \\
\hline Description & $\begin{array}{l}\text { Standards for independence } \\
\text { The Japanese legal framework contains basic standards for independence of external auditors } \\
\text { which require them to perform their services from an independent standpoint (CPA Act, Article 1). } \\
\text { Such basic standards are further developed in other laws and regulations (contained in the CPA } \\
\text { Act and Taxation legislation), and encompass both the individual CPA and audit firms. } \\
\text { In connection with the individual CPA, Article } 24 \text { of the CPA prohibits an auditor from } \\
\text { conducting an audit in the following circumstances: } \\
\text { - The auditor has a "substantial interest" in the entity subject to audit. This includes } \\
\text { debtor/credit relationship, ownership of securities and economic interests (including with any } \\
\text { director of the audit client). } \\
\text { - The auditor was a past director/employee of the entity. } \\
\text { The auditor provided advice or services such as taxation advice, development of IT or } \\
\text { management financial or accounting systems, property or valuation, outsourcing of internal } \\
\text { audit, and preparing financial statements for audit or exercising business judgment for the } \\
\text { client (participation in business decision making). } \\
\text { The prohibitions include a spouse of the auditor. } \\
\text { In regard to audit firms, Article } 34-11 \text { of the CPA Act prohibits an audit firm from providing audit } \\
\text { services in the following cases: } \\
\text { - When the audit firm owns stock or invests in the company. } \\
\text { When a partner who participates in the audit engagement has become an officer or taken an } \\
\text { equivalent position in the company. }\end{array}$ \\
\hline
\end{tabular}


- When the audit firm has a substantial interest in the company, which is defined in broad manner as a relationship concerning business, accounting or other matters (see description above).

Articles 24-2 and 34-11-2 of the CPA Act respectively prohibit an individual CPA and an audit firm from auditing the financial statements of a large company if the CPA or firm (or an entity substantially controlled by it) continuously receives fees for complementary services from a large company.

JICPA also imposes ethical rules covering the supply of services by its members, dealing with self-interest, self-review, advocacy, familiarity, or intimidation.

\section{Auditor rotation}

The CPA Act provides that each individual CPA and engagement partner of audit corporations must rotate for particular audit engagements of listed companies and certain large companies at least every seven years with cooling-off periods of two years. Partner rotation is required for the FIEA audits and certain large company audits pursuant to the Companies Act (Articles 24-3 and 34-11-3).

The CPA Act established a self-regulatory rotation rule for audit corporations auditing 100 or more listed companies to follow a five-year rotation rule with a five-year cooling-off period for the lead engagement partners and the lead examiners (Article 34-11-4).

\section{Internal controls}

Audit firms are required to develop their own service management systems to ensure the proper performance of services and of policies to control the quality of services (CPA Article 34-13). An audit firm must have operational controls to enable it to deliver a fair and appropriate service to the client and manage conflicts of interest. As per conversations with market participants and relevant authorities such type of controls are much more developed in the larger (global) firms. In their cases, in addition to the local risk managers there are global ethics committees in charge of reviewing that engagements respect the independence principle. Examples were given of cases where such controls resulted in the refusal to accept an engagement.

\section{Oversight of the selection process}

Pursuant to Articles 344 and 404 of the Company Act, the selection of external auditors is made by shareholders' meeting, but with prior consent from the corporate auditors, the board of auditors or the audit committee (for those corporations that have adopted the newer "occidental" style of corporate governance).

For listed companies, stock exchanges require the establishment of a board or committee of company auditors (TSE Rule for Security Listing Article 437 ii, OSE Rule for Business Behavior of Company Article 8 (1) ii). The board of company auditors decides the agenda and proposals of the selection of external auditors which it plans to submit to the shareholders meeting (Company Act Article 404(2) ii). The board of company auditors comprises three or more company auditors, and more than half must be independent auditors (Company Act Article 335(3). Under the definition, of independent auditors, (Company Act Article 2 xvi) a person who has been employed by the subject firm and its subsidiary as a management or staff member is not regarded as "independent," but a person working for the parent of a "sister" company for example would not be disqualified. Market participants commented that under the traditional system of corporate governance, corporate auditors or boards of auditors are not always perceived as sufficiently 


\begin{tabular}{|c|c|}
\hline & $\begin{array}{l}\text { independent, and the necessary expertise to provide robust oversight in financial matters might be } \\
\text { lacking. } \\
\text { If there is a change of auditor, the issuer must, without delay, submit to the Director General of the } \\
\text { Local Finance Bureau an extraordinary securities report which describes the situation. This report } \\
\text { must also be made available to the public (FIEA Article 24-5 and Cabinet Office Ordinance). } \\
\text { Oversight by JICPA } \\
\text { Auditors' independence is overseen by JICPA which performs quality control reviews to verify the } \\
\text { status of audit quality control in CPAs and audit firms, including compliance with standards for } \\
\text { the independence of auditors. } \\
\text { The review procedures include interviews with professional personnel at various levels and the } \\
\text { review of relevant audit working papers. In accordance with JICPA Quality Control Standards } \\
\text { Committee Statement No. } 1 \text { and Auditing Standards Committee Statement No. 32, and other } \\
\text { relevant standards, reviewers are to examine whether audit firms (including both audit } \\
\text { corporations and sole practitioners) properly adopt the professional requirements of independence, } \\
\text { integrity, confidentiality, and professional behavior. Also, reviewers examine: (a) whether } \\
\text { necessary skills and competence are attained and maintained through continuing education; (b) a } \\
\text { proper assignment policy, such as to whether the partner rotation rule has been implemented; (c) } \\
\text { audit engagements are independently reviewed by an independent engagement quality control } \\
\text { reviewer; (d) acceptance and retention of clients are properly controlled; and (e) monitoring is } \\
\text { adequately provided. } \\
\text { Based on the review, a written report is addressed to the firm's chief executive partner after the } \\
\text { deliberations of the Quality Control Committee. If reviewers learn of anything that needs } \\
\text { improvement or that the reviewed firm has not conformed to quality control policies and } \\
\text { procedures, the findings and recommendations are to be reported to the firm for adoption. }\end{array}$ \\
\hline Assessment & Broadly Implemented \\
\hline Comments & $\begin{array}{l}\text { Question } 6 \text { of the Methodology requires a governance body independent from management to } \\
\text { oversee the selection and appointment of the external auditor, and governance standards intended } \\
\text { to promote monitoring and safeguarding of the independence. In the context of Japan, such } \\
\text { function is exercised through the board of auditors (as very few companies have chosen the } \\
\text { committee system). Given current market views (which are also validated by reports carried out by } \\
\text { independent groups, which are available in the website) the assessors recommend that in the } \\
\text { context of public issuers the authorities consider reviewing the effectiveness of current governance } \\
\text { requirements relevant for the oversight of auditors' selection and auditors' independence. }\end{array}$ \\
\hline Principle 21. & Audit standards should be of a high and internationally acceptable quality. \\
\hline Description & $\begin{array}{l}\text { Standards adopted } \\
\text { The regulatory framework requires the financial statements included in public offering documents } \\
\text { and listing documents be prepared based on audits performed in accordance with generally } \\
\text { accepted audit standards and practices (Cabinet Office Ordinance on Audit Certification of } \\
\text { Financial Statements Article } 3(2) \text { ). } \\
\text { In Japan, the Business Accounting Council (BAC), an advisory body established within the FSA, } \\
\text { is in charge of developing the Auditing Standards, and the basic framework for auditing standards, } \\
\text { while the JICPA issues the Implementation Guidance, the guidelines for applying the Auditing } \\
\text { Standards (see below). The Auditing Standards and Implementation Guidance, as a combined set, } \\
\text { constitute Generally Accepted Auditing Standards (GAAS) in Japan. }\end{array}$ \\
\hline
\end{tabular}




\begin{tabular}{|c|c|}
\hline & $\begin{array}{l}\text { Organization responsible for standards } \\
\text { As indicated above, audit standards are established through a process which involves the BAC. } \\
\text { The BAC is a body within the FSA in charge with an advisory role in regard to the development of } \\
\text { accounting and auditing standards. The Commissioner of the FSA appoints Council members with } \\
\text { academic backgrounds. } \\
\text { The process for setting standards involves discussion with interested parties and within FSA. } \\
\text { When a draft set of standards has been prepared, they are submitted for public consultation via an } \\
\text { "exposure draft" in respect of which interested parties are invited to comment. After comments } \\
\text { received are considered, the standards are refined if necessary and finalized. When finalized, the } \\
\text { standards set by the Council are published as generally accepted standards. } \\
\text { The audit practice guidelines are prepared by the JICPA after a public comment process and } \\
\text { having passed through the Business Accounting Council. } \\
\text { The practice of the BAC and JICPA has been to revise the local standards immediately after } \\
\text { revisions are approved to the IAS. As a result FSA staff considers that there are no significant } \\
\text { differences between IAS and Japanese auditing standards. } \\
\text { Mechanism for enforcing compliance with auditing standards } \\
\text { The main mechanism to ensure compliance with auditing standards is the quality control review } \\
\text { conducted by JICPA. Enforcement actions can be imposed as described under Principle } 19 .\end{array}$ \\
\hline Assessment & Fully Implemented \\
\hline Comments & -- \\
\hline Principle 22. & $\begin{array}{l}\text { Credit rating agencies should be subject to adequate levels of oversight. The regulatory system } \\
\text { should ensure that credit rating agencies whose ratings are used for regulatory purposes are subject } \\
\text { to registration and ongoing supervision. }\end{array}$ \\
\hline Description & $\begin{array}{l}\text { Use for regulatory purposes, recognition criteria and registration under the ECAI } \\
\text { Credit ratings are only used for regulatory purposes in Japan in relation to the capital adequacy } \\
\text { regulations. Only entities recognized by the FSA as an external credit assessment institution } \\
\text { (ECAI) under Basel II principles can be used for this purpose, pursuant to the Notification } \\
\text { regarding recognition of external credit assessment institutions and classifications of ratings } \\
\text { applicable to banks' capital adequacy ratio calculation ("the Notification"). Recognition criteria } \\
\text { include six elements (Objectivity, Independence, International Access/Transparency, Disclosure, } \\
\text { Resources and Credibility); also refer to the IOSCO Code of Conduct Fundamentals for Credit } \\
\text { Rating Agencies. Those criteria conform to Basel II and Basel III (on paragraph } 90 \text { and 91). A } \\
\text { CRA that wants to be recognized as an ECAI must submit a request to the FSA. Pursuant to } \\
\text { Article } 2 \text { of the Notification in connection with Article 14-2 of the Banking Act the FSA can } \\
\text { refuse to recognize a CRA as an ECAI if it does not comply with the recognition criteria. } \\
\text { There is a separate registration process for CRAs, based on the FIEA which applies to any CRAs, } \\
\text { whose ratings are used for regulatory purposes or not. Such process was introduced in April 1, } \\
2010 . \\
\text { In practice, these two procedures have worked together, as all CRAs whose ratings are used for } \\
\text { regulatory purposes have registered with the FSA under the FIEA. Such designated ECAIs are: } \\
\text { three major foreign CRAs (Moody's, S\&P, and Fitch) and two domestic CRAs (JCR and R\&I), all } \\
\text { of which are registered under the FIEA regime. } \\
\text { The current regulations allow foreign CRAs to register themselves with the FSA without the need }\end{array}$ \\
\hline
\end{tabular}


to be incorporated domestically if the system of oversight in their home country is considered equivalent. The Commissioner of the FSA determines the process of equivalence by "designating" countries with appropriate regulation of CRAs as permitted to operate in Japan. However foreign entities have chosen to register their local operated subsidiaries with the FSA.

\section{Definition}

The FIEA defines credit rating (a grade which indicates by symbols or figures the assessment of the credit worthiness of financial instruments), credit rating business (business of determining credit ratings and providing them to a person or the public) and CRAs (person registered to conduct credit rating business (Article 2 (34-36) and Article 66-27).

\section{Regulatory requirements}

CRA's are required to conduct their operations with fairness and integrity as independent entities. They must establish quality control systems, ensure the independence and fairness of ratings and prevent conflict of interests. Ratings are prohibited where the CRA has a close relationship with an issuer, where they give advice on matters that may materially affect credit ratings or any acts resulting in insufficient protection of investors or loss of investor confidence in the credit rating business. CRAs are obliged to make timely information disclosure, including publishing their ratings policies and periodic disclosure of explanatory documents.

\section{Registration requirements}

To obtain registration, applicants are obliged to submit application documents containing all the information that the FSA deems necessary and to demonstrate they meet FSA regulations (based on IOSCO's Code of Conduct Standards). Details include:

- Relevant details of the applicant and its business and management systems to prevent conflicts of interest and arrangements to ensure that the ratings service is of quality.

- Information to demonstrate that it is capable of fairness and appropriateness (FIEA Article 6628), ratings to be determined by a ratings committee with rotation of members.

- Its financial statements (including annual report and income and loss statement). No minimum capital is required.

- Applicant's policies and methods concerning assignment of credit ratings. These must stipulate decisions only after comprehensive review of all relevant information. FIEA requires the ratings business to be conducted in accordance with such policies (Article 66-36).

- Applicant's business management systems to fairly and accurately perform credit rating business and to continuously conduct verifications and updates of assigned ratings (FIEA Article 66 and Cabinet Office Ordinance on Financial Business Instruments).

- An explanation of how people with specialized knowledge and skills, to ensure quality of information, will be used in assigning ratings, including sufficient staff with expertise and skills.

- Details of conflict of interest policies (discussed below).

The FSA has power to refuse to register a CRA where appropriate causes for refusal exist (FIEA Article 66). 


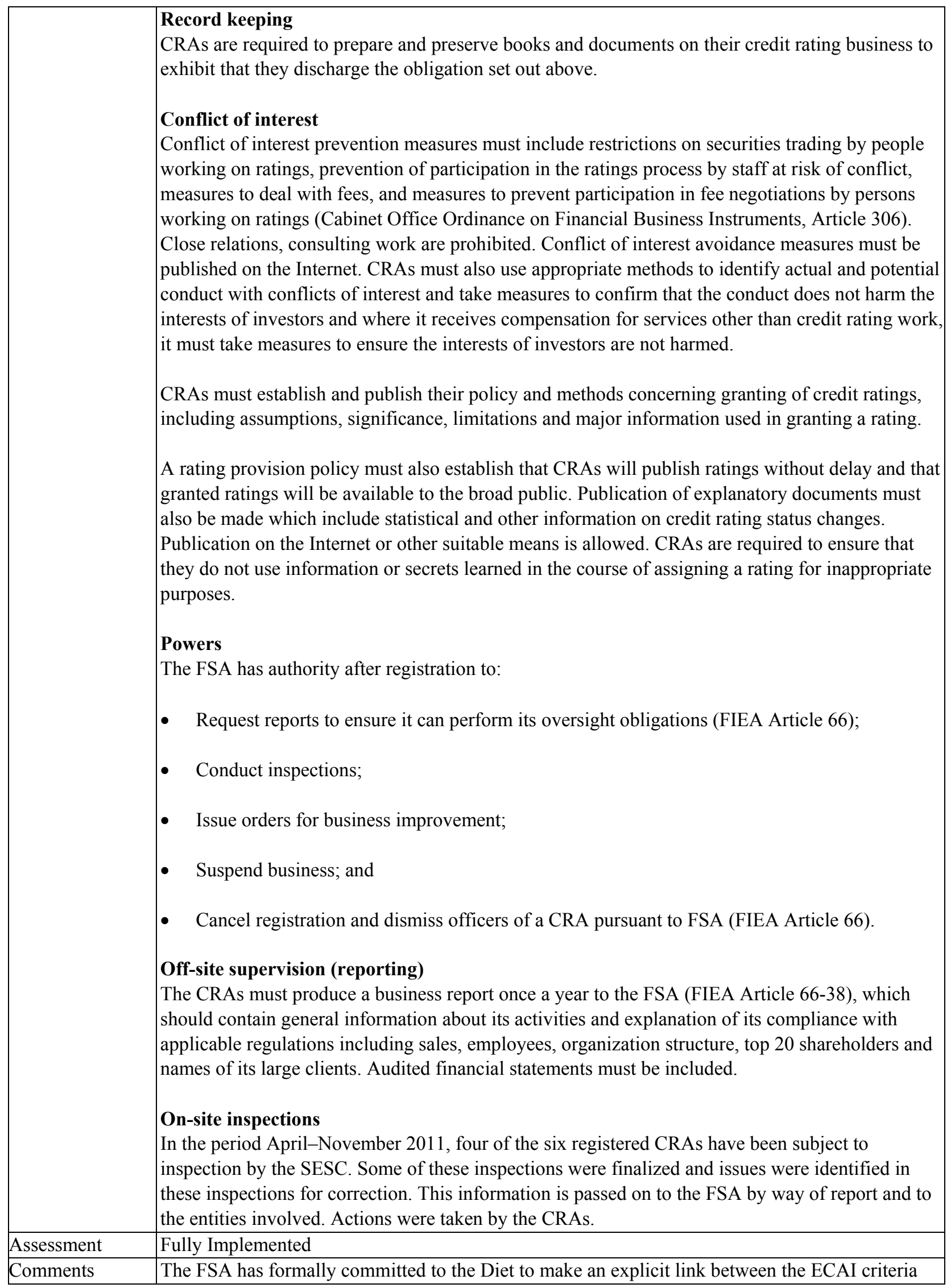




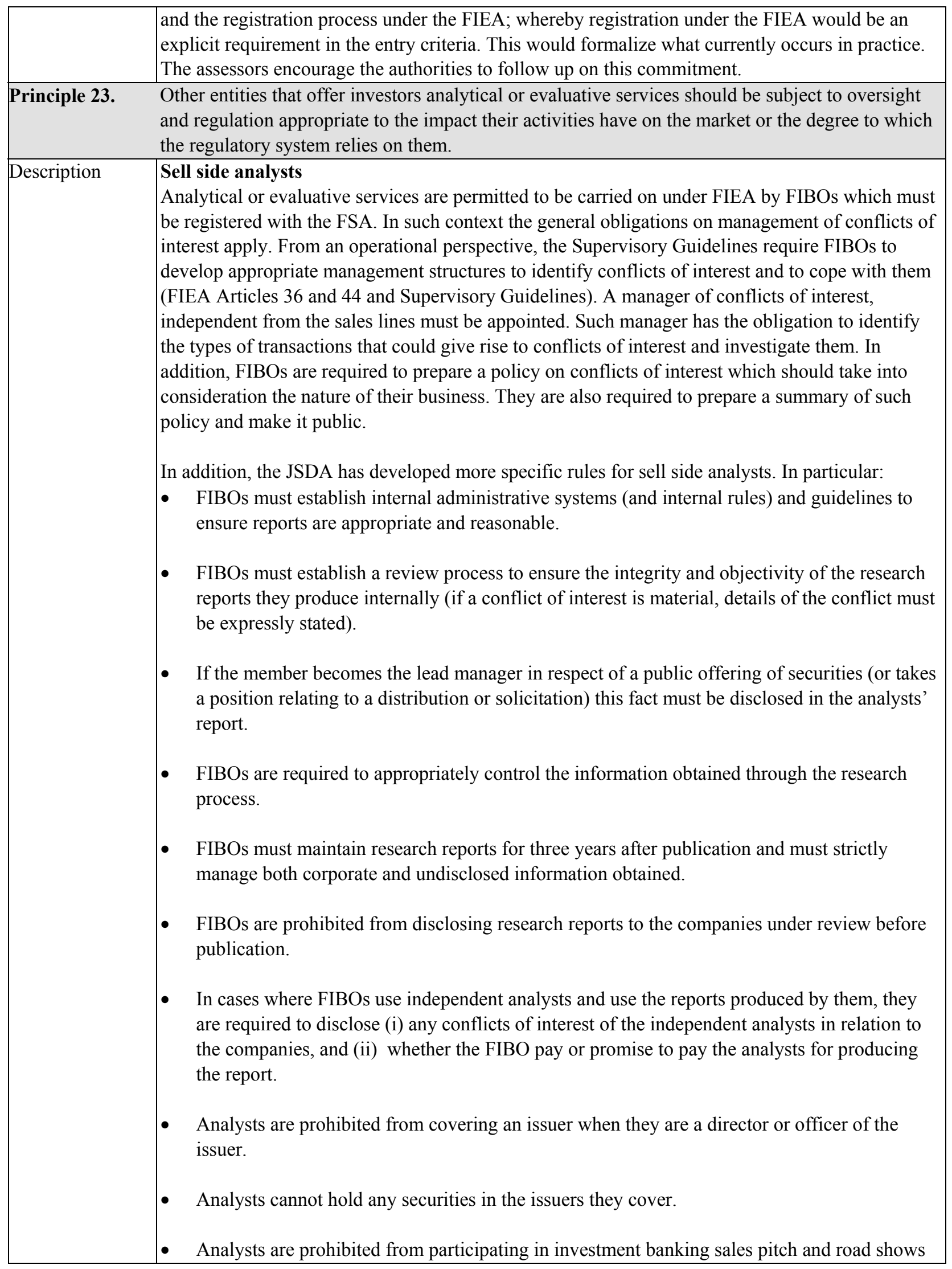




\begin{tabular}{|c|c|}
\hline & $\begin{array}{l}\text { and officers of the underwriting or investment banking divisions are prohibited from engaging } \\
\text { sales analysts in sales pitches. } \\
\text { Obligations on conflicts of interest are monitored via the on-site inspections carried out by the } \\
\text { JSDA and the SESC. } \\
\text { Other information services } \\
\text { Currently there are no other information services for which the FSA has considered necessary the } \\
\text { development of regulations to address potential conflicts of interests. } \\
\text { In the context of the valuation of CIS portfolios current regulations require an independent } \\
\text { valuation for illiquid assets. These services are provided by a variety of participants, including real } \\
\text { estate appraisers for real estate valuation and other type of information vendors (typically third } \\
\text { parties not related to the CIS manager or its group) for unlisted shares and other illiquid securities. } \\
\text { Submission of independent valuations is also required in certain cases in connection with tender } \\
\text { offers, mainly MBO. }\end{array}$ \\
\hline Assessment & Fully Implemented \\
\hline Comments & $\begin{array}{l}\text { The JSDA introduced a first set of rules on sell-side analysts in } 2002 \text {. Such rules were reformed in } \\
2004 \text { to introduce best practices from IOSCO's technical reports as well as recommendations } \\
\text { arisen from SESC inspections. In particular as a result of the former, provisions were added in } \\
\text { regard to the independence of the analysts from the investment banking unit and the prohibition to } \\
\text { have the salaries linked to such operations. As a result of the latter the regulations now deal } \\
\text { explicitly with independent analysts. Such review demonstrates that the FSA and the SRO have } \\
\text { paid attention to this issue. } \\
\text { The assessors encourage the authorities to review whether there is a need to develop regulations } \\
\text { for experts that provide valuation services to CIS, as well as for the experts that provide } \\
\text { independent valuations in connection with tender offers. }\end{array}$ \\
\hline \multicolumn{2}{|r|}{ Principles for Collective Investment Schemes } \\
\hline Principle 24. & $\begin{array}{l}\text { The regulatory system should set standards for the eligibility, governance, organization and } \\
\text { operational conduct of those who wish to market or operate a collective investment scheme. }\end{array}$ \\
\hline Description & $\begin{array}{l}\text { Definition of CIS } \\
\text { In general, in Japan the definition of CIS covered by the ITIC and the FIEA is linked to the type of } \\
\text { assets in which a pool of assets from investors is invested and the type of the legal structure } \\
\text { adopted. A manager of an investment corporation (IC) or an investment trust under the ITIC have } \\
\text { to be registered, regardless of the assets invested, and are the funds subject to the disclosure } \\
\text { requirements for a CIS under the FIEA. Conversely a manager of a partnership-type fund under } \\
\text { the FIEA that does not invest at least } 50 \text { percent in securities does not have to be registered, nor } \\
\text { are the funds subject to the disclosure requirements for a CIS under the FIEA. However the } \\
\text { distributor is subject to the FIEA and therefore is required to be registered. There is no limit to the } \\
\text { number of investors to which this type of funds can be offered, nor the amount of money that can } \\
\text { be raised. This partnership-type fund is the type of funds that are usually distributed by Type II } \\
\text { FIBOs. As per information compiled by the FSA based on an annual fund monitoring survey, the } \\
\text { majority of such funds are small (AUM is less than ¥10 billion) and leverage is low (less than } 200 \\
\text { percent). } \\
\text { Especially, the treatment of CIS that invests in real estate depends on the legal structure adopted. } \\
\text { A CIS that invests in real estate and takes the legal form of an IC is subject to the ITIC. Since the } \\
\text { equity of an IC under the ITIC is treated as a security, in case of a public offering, it is subject to } \\
\text { public disclosure requirements under the FIEA. A CIS that invests in real estate and takes the form }\end{array}$ \\
\hline
\end{tabular}


of a partnership is not regulated by the ITIC. Since the interest in a partnership that invests in real estate is not treated as a security, it is not subject to the requirement of disclosure in public offering, regardless of the number of investors. However distributors are required to make certain disclosures obligations to investors.

Finally the interest of a partnership which does not invest in real estate is subject to the FIEA. Accordingly such interest is subject to the requirements of disclosure in public offering where the partnership invests more than 50 percent of its assets in securities (including trusts beneficiaries of real state) and raises money from no less than 500 persons.

\section{Eligibility of operators and distributors}

\section{Operation/management}

The management of a CIS can only be carried out by a FIBO registered with the FSA as an IMBO (Article 29 of FIEA Article 3, 198 and 199 of ITIC).

The requirements are set forth in the FIEA and the Ordinance (Article 29-4 (1)), and include:

- A minimum capital of $¥ 50$ million.

- Sufficient resources.

- Adequate internal controls and risk management systems (Article 29-4 (1) of the FIEA VI-31-1 of the Supervisory Guidelines).

- Establishment of a compliance unit independent of the asset management unit (Article 29-4 (1) of the FIEA VI-3-1-1 of the Supervisory Guidelines).

- Fit and proper requirements for officers (which mainly focus on the integrity of the officers).

In the case of real estate investment corporations, the IMBO must obtain a special authorization.

IMBOs are required to notify material changes to the FSA, as well as violations to the FIEA as would any other FIBO.

\section{Distribution}

The distribution of CIS units can only be carried out by a FIBO registered with the FSA or by a financial institution also registered with the FSA (banks, insurers, cooperatives) and requires a separate registration as a distributor of CIS units.

Distributors are required to notify material changes to the FSA, as well as violations to the FIEA as any other FIBO.

\section{Registration process}

The registration process for IMBOs is the same as that for any other FIBO, which is explained in detail under Principle 29. This means that it is carried out by the local finance bureaus. As stated therein, there is a basic due diligence process, carried out through desk review and interviews. The inspection program does not contemplate on-site inspections for new registrants early after registration.

\section{Governance}

A general duty of loyalty and a duty of care as a prudent manager vis-à-vis unit holders are 
prescribed by the FIEA (Article 42 (1) and (2)).

In addition, an IMBO must be a corporation which has a company auditor or board of company auditors (FIEA Article 29-4 (1)). Such board has an oversight role over the affairs of the company. Market participants commented that some of the members are former staff of the company, but there are also outside members (and in companies with a board of auditors the law requires that the majority be outsiders).

According to FSA, staff and market participants larger FIBOs and IMBOs use a committee system, whereby such committees exercise an oversight role over the functions carry out by the FIBOs and IMBOs.

\section{Powers}

The powers of the FSA/SESC over IMBOs are the same as over any other FIBO, which are described in Principle 29. Accordingly such powers include the possibility to request reports and conduct inspections. Enforcement measures include orders for improvement, suspension for no more than six months and cancellation of registration.

\section{Oversight}

Off-site reporting

As a FIBO, an IMBO is required to submit a business report on an annual basis. Such report includes financial statements as well as other information on the status of the business. IMBOs are also required to notify material changes and violations of the law (see Principle 29). Financial statements are not required to be audited except for large companies, as per the Companies Act. FSA staff indicated that in practice the majority of IMBOs submit audited financial statements.

In connection with the CIS that it manages, the IMBO has to submit to the FSA and to investors (in the latter case through the distributors) an investment report for each fund it administers, on an annual basis as well as at the end of the accounting period of the CIS (Article 14 (3) of the ITIC Act for ITIC. In practice this means that they submit investment reports on a semi-annual basis. The investment report contains information on the fund (portfolio composition, value, etc). The law does not require that such report be disclosed to the public but in practice they are usually disclosed through the website of the IMBO.

In addition, based on the general powers to request reports, the FSA conducts a "funds monitoring survey" on an annual basis, whereby IMBOs are required to submit a report on the funds they administer (trends) and distributors of CIS a report on their distribution efforts.

ITAJ also requires CIS to fill out an annual questionnaire on the industry, as well as to report information on a monthly basis on the funds they administered.

Off-site monitoring

The FSA conducts off-site monitoring of the IMBOs and the funds they administer based on the reports that they are required to submit to the FSA, as well as information in the media, complaints, and the findings from the regular on-site inspections. For example, based on the annual fund monitoring survey the FSA produces a report that it shares with the SESC and publishes on the website.

FSA staff also noted that they keep a close relationship with IMBOs, so that they are alert to important developments. An example of such ad-hoc monitoring occurred after the failure of Lehman Brothers, when some REITs experienced funding problems. In such case, the FSA 
checked on their situation via ad-hoc reporting.

On-site inspections

SESC

The process to determine the number of IMBOs to inspect, the firms to be inspected and the focus of inspection is imbedded into the general plan of inspections described in Principle 12. Accordingly, the larger IMBOs get inspected more regularly, roughly every three years. Medium-size IMBOs would get inspected on a five year cycle. Cycles for smaller IMBOs (which would only manage discretionary/individual accounts) would be longer. As per comments from participants as well as files produced by the SESC, the inspections seem thorough. For a large IMBO, they can last four to six weeks.

Participants commented that the FSA and the SESC have been placing special emphasis on suitability obligations in connection with complex products, including funds. In such context the FSA has implemented stricter suitability standards for complex products. Additional guidance has been issued by the JSDA as well as ITAJ.

Enforcement

As indicated by the statistics included in Principle 12, during from 2008 to 20109 orders for improvement and three suspensions were imposed on IMBOs (see additional comments in Principle 12)

\section{ITAJ}

As indicated in Principle 9, the ITAJ also conducts inspections of IMBOs. There is no ex-ante division of "responsibilities" with the SESC. However, on an annual basis ITAJ produces its inspection plan and discusses it with the SESC, in order to avoid overlap. Once it is finalized, the plan is disclosed to ITAJ members. The IMBOs to inspect are selected based on a set of criteria:

- Inspection plan of the SESC;

- $\quad$ Cases referred by the SESC;

- Results of a survey prepared by ITAJ on an annual basis;

- Notifications of violations; and

- Complaints.

Inspections are announced. As per comments from market participants ITAJ's inspections last for about five days and involve teams of four to five people (some are former FSA/SESC staff). They are focused on particular areas.

Enforcement actions by ITAJ are not publicly disclosed (see enforcement actions in Principle 9)

\section{Recordkeeping}

IMBOs are required to prepare and preserve books and documents on the business for a period of five to ten years (Article 47 of the FIEA and Art 181(3) of Cabinet Office Ordinance on Financial Investment Business).

\section{Conflicts of interest}

The FIEA establishes a general duty of loyalty and a duty of care as a prudent manager vis-à-vis 


\begin{tabular}{|c|c|}
\hline & $\begin{array}{l}\text { CIS holders (Article } 36 \text { (1) and Article } 42 \text { (1) and (2) of the FIEA). } \\
\text { In addition, IMBOs, their board members and operating officers are prohibited from transacting } \\
\text { with the funds they administer; except if agreed in advance by the CIS holders and with the } \\
\text { approval of the FSA (Article } 42-2 \text { of the FIEA Article } 128 \text { and Article } 129 \text { of the Cabinet Office } \\
\text { Ordinance on Financial Instruments Business, etc.). An IT must disclose to investors transactions } \\
\text { made with interested counterparties (Article 13 (1) of the ITIC). A similar obligation exists for an } \\
\text { IC, where the IMBO must disclose the transaction to the IC (Article } 203 \text { (1) and (2) of the ITIC). } \\
\text { IMBOs are also prohibited from providing special profits (Art } 38 \text { (vii) of the FIEA Cabinet Office } \\
\text { Ordinance on Financial Instruments Business, etc., Article } 117 \text { (1) (iii)). } \\
\text { In addition, as a FIBO, IMBOs are subject to the duty of best execution (Article } 40-2 \text { of the FIEA). } \\
\text { They are also prohibited from doing unnecessary transactions (Art } 42-2 \text { (vii) of the FIEA } \\
\text { Article130 (1) (iii) of the Cabinet Office Ordinance on Financial Instruments Business, etc.). } \\
\text { Delegation } \\
\text { The FIEA allows an IMBO to delegate decisions on investment (full or part) of a specific fund in } \\
\text { another FIBO, but it cannot delegate full investment decisions of all funds it administers. (Article } \\
42-3 \text { (2) of the FIEA Article } 12 \text { and } 202 \text { of the ITIC). Delegation arrangements must be included } \\
\text { in the Basic Terms and Conditions of the Investment Trust (Article } 4 \text { of the ITIC). } \\
\text { The FSA may order the entity in which investment was outsourced to submit reports and the SESC } \\
\text { can conduct inspections, as needed (Article 56-2 (1) of the FIEA Article } 213 \text { of the ITIC). The } \\
\text { FSA can also issue an order for improvement of business operation. (Article } 51 \text { (1) of the FIEA } \\
\text { Art } 214 \text { (1) of the ITIC). } \\
\text { The FSA informed that delegation is common for funds that invest abroad, in connection with such } \\
\text { portion of the portfolio. }\end{array}$ \\
\hline Assessment & Broadly Implemented \\
\hline Comments & $\begin{array}{l}\text { Questions } 8 \text { and } 9 \text { of the Methodology require that the regulator conduct inspections on CIS } \\
\text { managers and proactively investigative activities in order to identify suspected breaches of the } \\
\text { laws. } \\
\text { The understanding of the assessors is that the current risk based approach has ensured } \\
\text { periodic/regular inspections for CIS managers as they are the larger IMBOs (or at least } \\
\text { medium-size IMBOs). However, for the reasons stated in Principle } 12 \text { the assessors encourage the } \\
\text { authorities to review the current approach, including by enhancing the framework to determine } \\
\text { risks on individual firms, and the inspection program (either through more institution based } \\
\text { inspections, an/or thematic reviews and/or random inspections). Strengthening of the supervisory } \\
\text { program should also have an effect on enforcement actions. ITAJs enforcement actions seem } \\
\text { limited. It would be important that the FSA/SESC follows up on this aspect with ITAJ. } \\
\text { Concerns regarding other IMBOs that do not manage CIS (assets managers of individual and } \\
\text { discretionary portfolios) are discussed and accounted for in Principle 31, as per IOSCO's } \\
\text { definition of securities intermediaries. }\end{array}$ \\
\hline Principle 25. & $\begin{array}{l}\text { The regulatory system should provide for rules governing the legal form and structure of collective } \\
\text { investment schemes and the segregation and protection of client assets. }\end{array}$ \\
\hline Description & $\begin{array}{l}\text { Legal form } \\
\text { CIS in Japan can be constituted as a trust (investment trust or IT) or as a corporation (investment } \\
\text { corporation or IC) (ITIC, Article 2). }\end{array}$ \\
\hline
\end{tabular}




\begin{tabular}{|c|c|}
\hline & 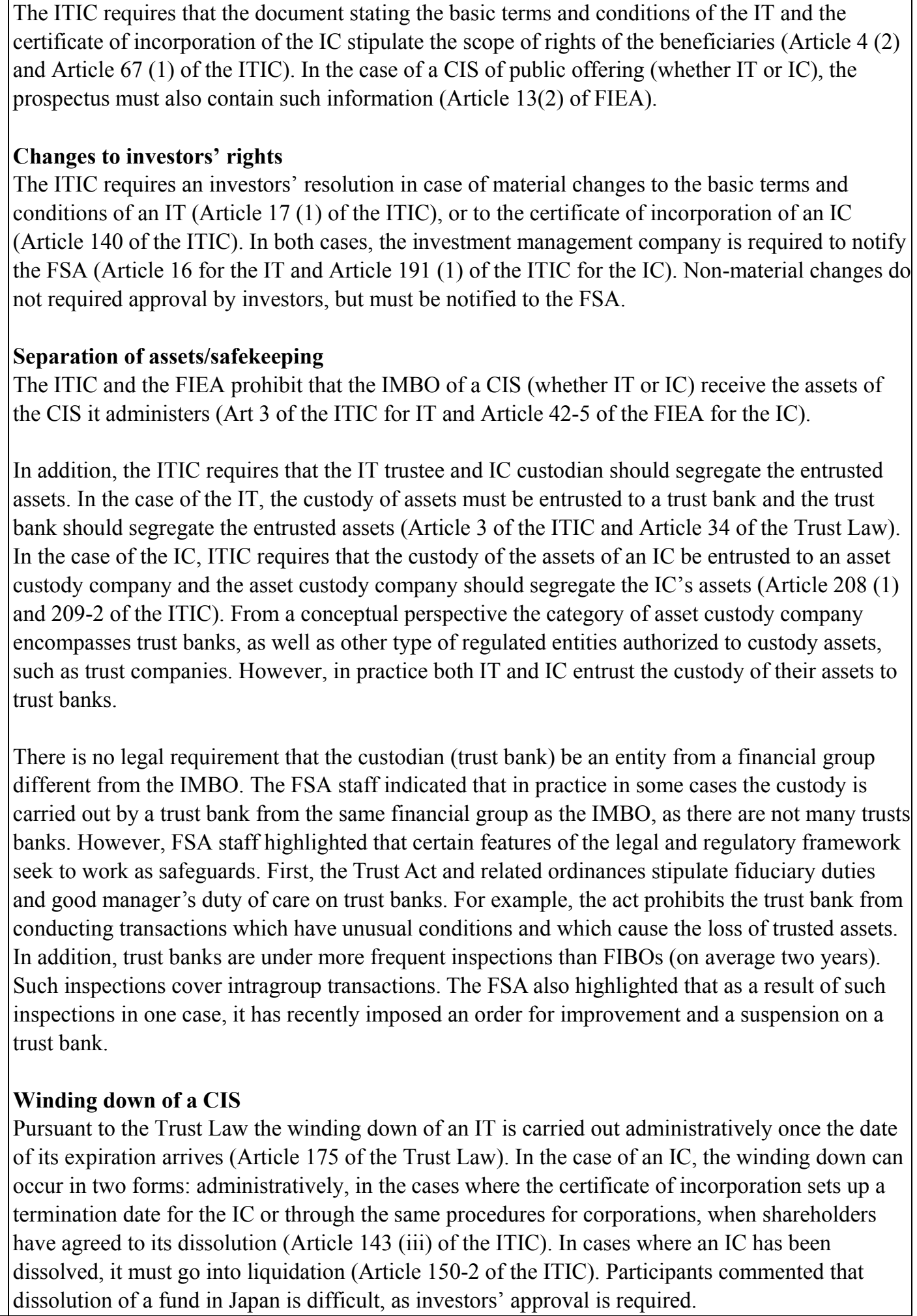 \\
\hline & Broadly Implemented \\
\hline
\end{tabular}




\begin{tabular}{|c|c|}
\hline Comments & $\begin{array}{l}\text { Question } 8 \text { of the Methodology requires that custody of assets be entrusted to independent entities, } \\
\text { and that if related entities were to be used then additional safeguards must be in place. The } \\
\text { assessors acknowledge the existence of certain features in the legal framework that aimed to } \\
\text { protect investors' interest. In particular, the fact that trust banks are subject to inspections by the } \\
\text { FSA. However the assessors believe that additional safeguards must be in place as per the } \\
\text { principles. Such safeguards could include, for example, specific reports to the FSA and investors } \\
\text { on the security of the assets and intra-group transactions. }\end{array}$ \\
\hline Principle 26. & $\begin{array}{l}\text { Regulation should require disclosure, as set forth under the principles for issuers, which is } \\
\text { necessary to evaluate the suitability of a collective investment scheme for a particular investor and } \\
\text { the value of the investor's interest in the scheme. }\end{array}$ \\
\hline Description & 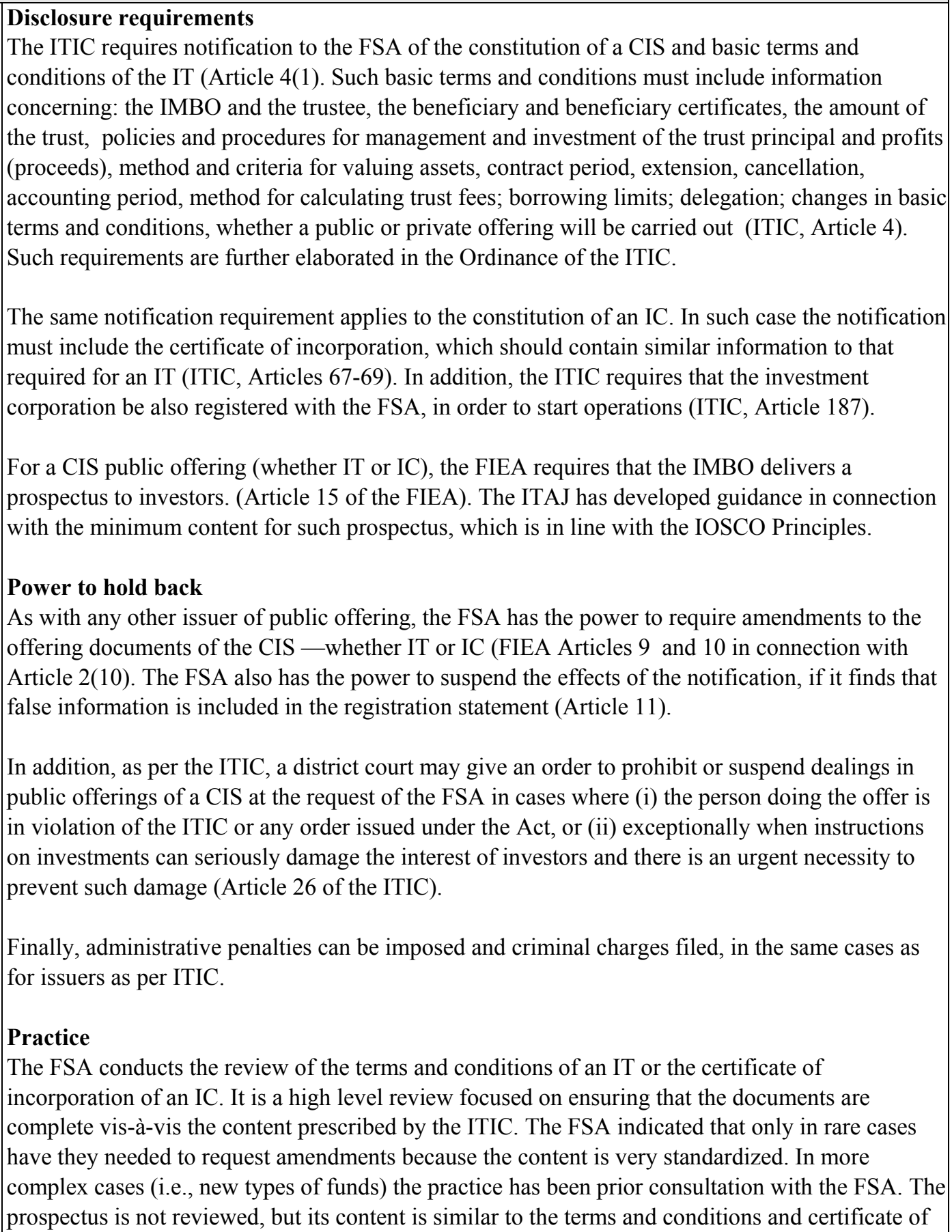 \\
\hline
\end{tabular}




\begin{tabular}{|c|c|}
\hline & $\begin{array}{l}\text { incorporation. Furthermore ITAJ has developed a template for prospectus as well as a typology of } \\
\text { funds. } \\
\text { Advertisement } \\
\text { The general rules of FIEA in regard to advertisement by issuers apply to CIS; that is, when } \\
\text { advertisement is carried out through means different from the prospectus, such means cannot be } \\
\text { misleading or include misrepresentations (Article 13(5) of the FIEA) } \\
\text { Periodic information } \\
\text { As indicated under Principle 24, the IMBO is required to submit to the FSA and distribute to } \\
\text { investors semiannual investment reports, which provide investors with up-to-date information on } \\
\text { the funds they are invested in. In the case of listed funds, quarterly reports apply as for any other } \\
\text { listed issuer. Annual reports must contain audited financial statements which must be prepared } \\
\text { according to Japanese GAAPs (Article } 3 \text { of the Ordinance on Accountings of Investment Trust } \\
\text { Property). } \\
\text { Powers to oversee investment policies } \\
\text { Overall compliance with investment policies is ensured via ongoing monitoring and on-site } \\
\text { inspections described in Principle } 24 \text {. }\end{array}$ \\
\hline Assessment & Fully Implemented \\
\hline Comments & -- \\
\hline Principle 27. & $\begin{array}{l}\text { Regulation should ensure that there is a proper and disclosed basis for asset valuation and the } \\
\text { pricing and the redemption of units in a collective investment scheme. }\end{array}$ \\
\hline Description & $\begin{array}{l}\text { Asset valuation } \\
\text { As per the Ordinance on Accountings of Investment Corporations and the Ordinance on } \\
\text { Accountings of Investment Trust, Japanese GAAPs must be used to value the assets of IT and IC. } \\
\text { The ITAJ has issued rules on valuation and accounting of assets (Rules, etc., on Valuation and } \\
\text { Accounting of Investment Trust Property). Such rules establish a general duty of loyalty and a } \\
\text { duty of care as a prudent manager in relation to the valuation of the assets incorporated in an } \\
\text { Investment Trust Property. The Rules also provide more specific guidance in connection with asset } \\
\text { valuation. Liquid assets are required to be valued at market prices (Article 3). For stocks this } \\
\text { means closing price on exchanges and for bonds reference values provided by the JSDA, bid } \\
\text { prices provided by securities firms or banks or prices supplied by price vendors; bonds with less } \\
\text { than one year maturity can be valued at amortized accost as adjusted every day). For illiquid assets } \\
\text { (unlisted securities and real estate) the ITIC requires an independent (third party) valuation both at } \\
\text { the moment of acquisition and transfer. } \\
\text { NAV } \\
\text { According to ITAJ Rules, the NAV and the base price per unit must be calculated daily (Article } 51 \\
\text { (2) and (3) and } 52 \text { of the Rules, etc. on Valuation and Accounting of Investment Trust Property). } \\
\text { The ITIC also requires that the subscription and redemption price be fair (Article } 82 \text { (6) and } 125 \\
\text { (1)). } \\
\text { The basic terms and conditions of the IT, and the certificate of incorporation of the IC must } \\
\text { contain information on subscription and redemption price (Article } 4 \text { (2) of the ITIC, Article } 8 \text { of } \\
\text { the Ordinance for Enforcement of the ITIC for the IT, Article } 83 \text { (1) and } 67 \text { of the ITIC, Article } \\
135 \text { and } 105 \text { of the Ordinance for Enforcement of the ITIC for the IC). Subscription and } \\
\text { redemption prices must be disclosed daily on the website of the ITAJ, as well as on the website of } \\
\text { the IMBO. }\end{array}$ \\
\hline
\end{tabular}




\begin{tabular}{|c|c|}
\hline & $\begin{array}{l}\text { Pricing errors } \\
\text { ITIC requires that pricing errors due to negligence be borne by the IMBO (Article 21). The } \\
\text { Inspection Manual for IMBOs requires the review of the systems to value CIS. Such review covers } \\
\text { issues such as whether an internal system to value accurately portfolio assets has been developed, } \\
\text { whether verifications are carried out, whether adequate measures exist for cases of pricing errors } \\
\text { and actions are taken accordingly. } \\
\text { Suspension of redemptions } \\
\text { The conditions for redemptions have been left to the terms and conditions of the IT. ITAJ has } \\
\text { issued a memorandum in connection with the cases where suspensions can take place. Pursuant to } \\
\text { the ITAJ Rule, IMBOs must notify to the ITAJ suspensions of redemptions. In turn, ITAJ notifies } \\
\text { it to the FSA, pursuant to a FSA instruction. } \\
\text { There are no specific rules in regard to the actions that the FSA could take if a suspension is not in } \\
\text { the interest of investors. However the FSA believes that it could use its authority to issue an order } \\
\text { for improvement to require the lifting of a suspension. (Article 51, 52, 56-2 of the FIEA Art } 213 \\
\text { and } 214 \text { of the ITIC). } \\
\text { Examples were given of a recent experience with suspensions, where the ITAJ and the FSA kept } \\
\text { close monitoring of the situation. }\end{array}$ \\
\hline Assessment & Fully Implemented \\
\hline Comments & \\
\hline Principle 28. & $\begin{array}{l}\text { Regulation should ensure that hedge funds and/or hedge funds managers/advisers are subject to } \\
\text { appropriate oversight. }\end{array}$ \\
\hline Description & $\begin{array}{l}\text { Pursuant to the FIEA the management of a CIS, irrespective of whether they are public offerings } \\
\text { or not is a regulated activity that can only be carried out by a FIBO duly registered with the FSA. } \\
\text { As a result, fund managers of hedge funds have to register in with the FSA. } \\
\text { As far as the manager is concerned there are no differences in registration requirements for a } \\
\text { manager of hedge funds versus the manager of a CIS public offering. Thus, all the requirements } \\
\text { described in Principle } 24 \text { are applicable to hedge fund managers. Accordingly, there are } \\
\text { registration requirements applicable to fund managers including, minimum capital, as well as } \\
\text { appropriate resources. Also, requirements on internal controls and risk management, segregation } \\
\text { of investors' assets and management of conflict of interest apply to them. } \\
\text { In the same vein, the FSA has the same powers over managers of hedge funds that it has vis-à-vis } \\
\text { manager of CIS of public offering. Furthermore they are also subject to the same reporting } \\
\text { obligations as all other FIBOs, and to on-site inspections. } \\
\text { The main difference in treatment vis-à-vis managers of CIS of public offering relates to reporting } \\
\text { obligations in connection to the funds they administer. In this regard, the FIEA allows the terms } \\
\text { and conditions of an IT or the certificate of incorporation of an IC which is not of public offering } \\
\text { to determine the reporting that would be available to investors. Vis-à-vis the FSA, the only } \\
\text { reporting that currently would apply is the fund monitoring survey that the FSA conducts on an } \\
\text { annual basis. } \\
\text { There is no specific typology for hedge funds; thus it is difficult to determine in a rigorous manner } \\
\text { the size of the hedge fund industry in Japan. However, the FSA estimates that the industry is still } \\
\text { very small. A similar indication was given by market participants. }\end{array}$ \\
\hline
\end{tabular}




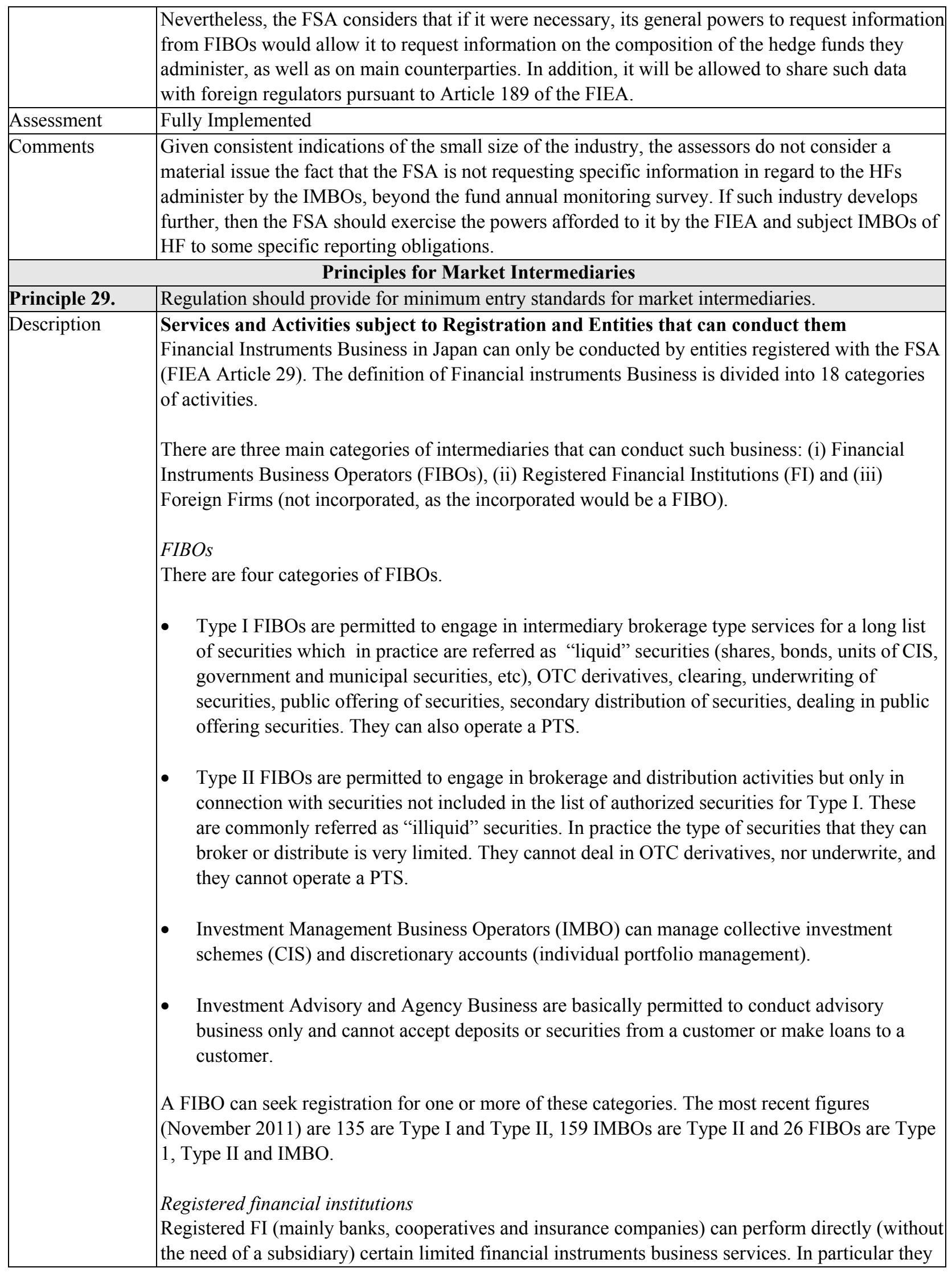


can distribute CIS and government securities. Trust banks, which are a particular type of bank, can also manage CIS. Finally, the legal framework allows banks to perform transactions in securities as a principal but not as an agent. In practice this means that they can trade OTC derivatives, and conduct proprietary trading provided that at the other end the counterparty is also a financial institution or a FIBO. These restrictions are set in FIEA Article 33.

In the provision of the services that they can conduct vis-a-vis retail investors FI are subject to the same regulations as any other FIBO. In all other aspects (i.e. capital and other prudential requirements and reporting obligations) they are subject to their corresponding legal framework.

Foreign firms

Foreign firms can choose to provide financial business services via an incorporated firm, in which case they are an ordinary FIBO, or as a branch. In such case, the foreign firm is required to bring to Japan ("internalize") capital. The home jurisdiction of the branch must be of equivalent regulatory standard.

Foreign securities firms cannot conduct sales and purchase of securities to a person in Japan other than financial institutions as the counter party. There is also a restriction on "wholesale" underwriting which can be permitted with FSA approval (FIEA Article 59).

In practice most foreign firms have chosen to incorporate and registered as FIBOs. There are only 22 not incorporated foreign firms.

\section{Registration requirements}

Registration with the FSA by any entity that wishes to conduct Financial Instruments Business is required (FIEA Article 29).

Minimum entry standards are established in the FIEA for each category of FIBO, and are set up essentially in the negative as grounds under which "refusal of registration" occurs (FIEA Article 29-4). Essentially all categories are subject to:

- Minimum capital requirements, net asset requirements and capital adequacy. The criteria vary depending on the type of FIBO (see below).

- The applicant's directors and officers are checked to ensure they have no recent criminal record or links to organized crime, and CVs are requested. If the applicant seeks registration as Type I (except foreign firms) the major shareholders are checked (but not other types). The shareholding percentage specified is 20 percent (or 15 percent if so stated in the Cabinet Ordinance) for this purpose (FIEA Article 29-4). Reports setting out business operations including risk management, internal control, details of shareholders and human resource structure are required.

- Sufficient resources.

- Adequate internal controls and risk management systems (Article 29-4 (1) of the FIEA VI-3-1-1 of the Supervisory Guidelines).

- Establishment of a compliance unit (Article 29-4 (1) of the FIEA VI-3-1-1 of the Supervisory Guidelines). 


\section{Registration process}

Applications for registration for FIBO, Registered FI and foreign securities companies are all processed in a similar manner. This occurs at the Local Finance Bureau where the head office of the applicant is located.

The Local Finance Bureau processing the application must follow the FIEA and the Supervisory Guidelines set down by FSA which requires checking of the capital requirements, personnel, internal control and risk management as submitted. The applicant and its staff are required to appear and answer questions at the Local Finance Bureau as part of the vetting process. Processing the application may take several months depending on the number of interviews/hearings conducted of the management and the issues that arise there from and the sufficiency of the information provided to verify operational, internal and procedural controls for the business and that personnel are appropriately skilled and knowledgeable. The person conducting the screening of the application prepares an internal report and a recommendation for registration for his/her superiors at the Local Finance Bureau. If the recommendation is to register the applicant, a copy of such recommendation (together with an executive summary of the application) is sent to FSA. To ensure that all such officers handling applications are adopting a consistent approach, once a year there is a training session for these officers by FSA. There is also ongoing training and secondment of staff in the Local Finance Bureau.

The FSA informed that very few applications get rejected, as there is a common practice of withdrawal in cases where the FSA has questioned whether the applicant meets the requirements.

There is no policy to inspect a FIBO within a set period (for example within 12 months of commencement of operations) and in particular in the case of small FIBOs the first inspection after registration might occur only if problems or issues arise in the conduct of its business or there is concern arising from its annual reporting obligation or the annual monitoring survey for funds which requires information on distribution of CIS.

\section{Powers of the FSA over securities intermediaries}

The FSA has a broad set of powers over securities intermediaries:

- It can request reports and conduct inspections.

- Issue orders for improvement (FIEA Article 51).

- Suspend some or all of the registrant's operations for a period not to exceed six months or cancel registration if there is a failure to meet the entry criteria.

Grounds include an applicant's past acts, its capital requirements, and violations of the FIEA or inadequate staffing (including violation of Financial Legislation or close links with organized crime).

\section{Material changes}

Any change in items listed in FIEA Article 29 (registration criteria expressed as grounds for refusal of registration) is required to be notified to the FSA within two weeks from the date of change (FIEA Article 31). Neither changes in executive officers or directors nor in major shareholders require pre-vetting by the FSA. However upon notification the FSA conducts verifications and if problems are found it can issue an order requesting changes.

Changes in officers or directors: The FSA checks to ensure that there is no known adverse criminal 


\begin{tabular}{|c|c|}
\hline & $\begin{array}{l}\text { record of the person; in addition as for any other director a curriculum vitae is required to verify } \\
\text { qualifications. If a director or senior manager resigns and the position remains vacant, a review of } \\
\text { the circumstances will be made. Subsequently when the position is filled, the newly appointed } \\
\text { person is required to report to Local Finance Bureau on any adverse legacy issues that that person } \\
\text { becomes aware of relating to the business. } \\
\text { For FIBOs Type I, changes to the shareholding structure in excess of } 20 \text { percent: a further check } \\
\text { will be made that the capital adequacy of the businesses is being maintained and that there is no } \\
\text { recent criminal record of the new shareholder. } \\
\text { Publicly available information } \\
\text { The FSA keeps a public register of all FIBOs, Registered FI and foreign securities companies, } \\
\text { which is available to the public via its web site (FIEA Article 29). The Japanese site displays } \\
\text { names, dates of registration, registration numbers and business types (the English version only } \\
\text { displays names, addresses and phone numbers under broad business headings). Further } \\
\text { information can be obtained on inquiry to the Local Finance Bureau. Registration certificates } \\
\text { (including managers' names) must be displayed to the public in each office by the registered } \\
\text { entity. } \\
\text { Investment Advisors } \\
\text { In Japan investment advisors are required to be registered as one category of FIBO, and therefore } \\
\text { are subject to registration with the FSA as explained above. } \\
\text { Accreditation of individuals } \\
\text { Individuals who want to engage in certain activities on behalf of a FIBO-for example sales } \\
\text { representatives-are required to be accredited by the JSDA. To be accredited an individual must } \\
\text { pass an examination with the JSDA. There is a requalification requirement every five years. The } \\
\text { JSDA keeps the registry of accredited individuals. }\end{array}$ \\
\hline Assessment & Broadly Implemented \\
\hline Comments & $\begin{array}{l}\text { Questions } 2 \mathrm{~d} \text { ) and e) and 3) require a comprehensive assessment of registration criteria. While the } \\
\text { hearings provide good insights into a firm prior to start up, certain aspects of its actual process and } \\
\text { operation require on-site inspection for full verification. Thus the assessors recommend that the } \\
\text { registration process be strengthened. In such context the assessors recommend that the authorities } \\
\text { review whether current fit and proper requirements are too narrowly defined. } \\
\text { In addition, the assessors encourage the authorities to review the current framework for changes in } \\
\text { key personnel and major shareholders, to determine whether a pre-approval system is warranted. }\end{array}$ \\
\hline Principle 30. & $\begin{array}{l}\text { There should be initial and ongoing capital and other prudential requirements for market } \\
\text { intermediaries that reflect the risks that the intermediaries undertake. }\end{array}$ \\
\hline Description & $\begin{array}{l}\text { Initial and ongoing capital requirements (minimum capital, net assets and capital adequacy ratio) } \\
\text { are required initially on registration and continuously (FIEA Articles } 29,31,46,52 \text {, and 53). } \\
\text { Minimum capital requirements } \\
\text { The requirements are for capital or deposits for operations of the following amounts: } \\
\text { - Type I Financial Business: } ¥ 50 \text { million (capital) (roughly US } \$ 621,000) \\
\text { - Type II Financial Business: } ¥ 10 \text { million (roughly US } \$ 124,000 \text { ) (deposits for operation) } \\
\text { - Investment Management Business: } ¥ 50 \text { million (capital) } \\
\text { - Investment Advisory and Agency business: } ¥ 5 \text { million (deposits for operation) }\end{array}$ \\
\hline
\end{tabular}


There are a number of the firms which are both Type I and Type II (there are also IMBOs that are Type II, and there are also Type I, that are also Type II and IMBO. In these cases, the higher requirement applies.

\section{Ongoing capital requirements}

Type I

For Type I FIBO, a capital adequacy ratio applies as per standards that are based on risk weighting assets and liabilities. The standards are stipulated by public notice for the calculation of market risk equivalent, counterparty risk equivalent and basic risk equivalent. The public notice sets out the risk weight of each risk asset.

The ratio is derived from a formula where the numerator is calculated by deducting the amount of illiquid assets (unlisted securities, loans and real estate) from the capital. The denominator is the equivalent of credit risk, market risk (the standard is the same as that of Basel II) and operational risk (calculated by multiplying the operating cost by 25 percent).

Overall the understanding of the assessors based on the information provided by the FSA and conversations with market participants is that the capital adequacy ratio for Type I FIBO is more conservative than Basel II, mainly due to (i) the deduction of more assets in the numerator, (ii) the fact that securities firms are not allowed to use internal models, only the standardized approach and (iii) the way operational risk is calculated.

Under the standards, liquidity risk is managed by measures such as daily fund raising, outlook for future fund raising, ensuring financing methods (payment reserve) to take account of a sudden change of business or in the market.

Liquidity risk is calculated by deducting the full amount of the illiquid assets (such as unlisted securities, loans and real estate) from the capital which is calculated on methods similar to calculating Tier 1, Tier 2 and Tier 3, of Basel II standards. In addition the FSA requires internal controls for managing liquidity risk.

Consolidated regulation and supervision was introduced in April 2011. This requires a Type I FIBO whose total assets are more than one trillion JPY to be designated as a Special FIBO. In such case it is required to calculate its capital adequacy on a consolidated basis. Where the Special FIBO and its parent conduct its business, the parent company is designated as a Designated Ultimate Parent Company. Such a Designated Ultimate Parent Company can select either the standard of consolidated regulatory capital adequacy ratio or the standard of consolidated capital adequacy ratio based on Basel II. Currently these designations have been made and they both have chosen the ratio based on Basel II.

All other FIBOs

For Type II FIBO, IMBO, Investment Advisory and Agency Business the ongoing capital requirements are the maintenance of the minimum capital requirements at registration, set out above.

\section{Reporting of capital adequacy}

Type I

Type I FIBOs are required to maintain records and calculate their own capital adequacy ratio. They are also required to prepare quarterly financial reports which are provided to FSA and published. These reports include capital adequacy, total assets, assets of clients outstanding and cash position. 
In addition, Type I must provide a monthly risk management report (containing financial information, balance sheet and capital adequacy calculation) to the FSA or the Local Finance Bureau but they do not make this publicly available. The monthly report must be in a set format, and be lodged by the $20^{\text {th }}$ of the following month (FIEA Article 46).

Type I are required to be aware of their capital ratio situation ("appropriate grasp") on a daily basis and take action if capital adequacy falls below a ratio of $140 \%$. If this occurs, they are required to prepare and submit daily notifications to the FSA of their financial position. If an operator's capital adequacy ratio falls below 120 percent, the FSA orders the operator to submit plans for specific measures to maintain or improve the ratio ("corrective action"). The process is regarded by FSA as "early warning" of potential issues which it will supervise closely on a daily basis.

All other FIBOs

For Type II FIBO, IMBO, Investment Advisory and Agency Business the ongoing capital requirements are the maintenance of the minimum capital requirements at registration, set out above. They do not file specific capital adequacy reports with the FSA, but they are required to submit a Business Report, which includes their financial statements, on an annual basis. Such Reports are lodged with the Local Finance Bureau. Such reports are not made publicly available. FSA staff indicated that, from a cost benefit view, such reporting requirements are sufficient, as the FSA would have the ability to impose ad hoc reporting on specific firms due to market or stress conditions.

\section{Auditing of financial position}

There is no requirement in the FIEA for external auditing of the financial statements of any FIBO. However based on obligations for public issuers on the FIEA and Company Law-as per the requirement for large companies - most Type I and IMBOs are audited externally. The remaining FIBOs must have internal audit reviews of their financial information by their "corporate auditors," but corporate auditors do not need to be CPAs. FSA staff highlighted that Type I FIBOS are required to submit an annual external audit of the segregation of customers' assets, and that from a cost benefit view it does not consider appropriate to require all FIBOs to have their annual financial statements externally audited.

\section{Review by the FSA of capital adequacy}

The specific reports on capital adequacy are the main mechanism to check capital adequacy for Type I FIBOs. The FSA/local finance bureaus supervisors are required to identify the margin and rate of change in FIBOs Type I capital adequacy each month and analyze risks which have materialized, as well as undertaking stress tests under criteria set by FSA. This analysis is translated into a monthly report that clearly identifies "problematic" Type I FIBOs, require to follow up on their actions to address "problems" and report on such actions. Reports can also be required under FSA's "early warning system" explained above. In addition on a quarterly basis the FSA produces a report where it provides an aggregated view of the sector.

For large complex firms the FSA has established the OSBM which is in charge of prudential supervision of such firms. In such case in addition to the reporting requirements for Type I FIBOs the Office has subjected each of the firms to tailor-made prudential requirements that allow it to follow more closely the positions and risk of each firm.

For Type II the annual Business Reports are used to check minimum capital. In addition, as distributors of "CIS" they are required to respond to the annual monitoring survey of the FSA. Such survey requires them to provide detailed information on their business, final position, sales made, etc. For IMBOs and FIAs the annual business report is also used to check capital. 


\begin{tabular}{|c|c|}
\hline & $\begin{array}{l}\text { Powers of the FSA in relation to Prudential Requirements } \\
\text { The FSA has the following powers to seek compliance with and address problems with capital and } \\
\text { other prudential requirements: } \\
\text { - Request reports } \\
\text { - Issue Orders for Improvement under FIEA (Article 51) } \\
\text { Suspend the registration } \\
\text { Risks for unaffiliated entities and off-balance sheet activities } \\
\text { For Type I FIBOs the Supervisory Guidelines permit a financial instruments' group to calculate its } \\
\text { own capital adequacy based on the standards described above. Consolidated regulation and } \\
\text { supervision was introduced in April } 2011 \text {. This requires a Type I FIBO whose total assets are more } \\
\text { than one trillion JPY to be designated as a Special FIBO. In such case it is required to calculate its } \\
\text { capital adequacy on a consolidated basis. As these are the larger institutions with diverse } \\
\text { operations, a significant risk factor has been covered. } \\
\text { In respect of all other categories the FSA relies on it's off- site monitoring and the inspection } \\
\text { process to pick up unaffiliated entities and off- balance sheet risk. FSA is for this purpose } \\
\text { authorized to obtain reports, conduct inspections and suspend business operations depending on an } \\
\text { adverse outcome of any review of capital of the registered entity. }\end{array}$ \\
\hline Assessment & Partly Implemented \\
\hline Comments & $\begin{array}{l}\text { Questions } 1,2,3 \text {, and } 4 \text { of the Methodology requires ongoing capital that is adjusted by risk and } \\
\text { that can allow smooth winding-down of the intermediary; Question } 6 \text { requires detail, format, } \\
\text { frequency and timeliness of reporting to the regulator (and /or SRO) in sufficient detail to reveal a } \\
\text { significant deterioration in the capital adequacy position of the market intermediary and } \\
\text { Question } 7 \text { requires the financial position of a securities intermediary to be subject to independent } \\
\text { audit in order to provide additional assurance that the financial position reflects the risks the } \\
\text { intermediary undertakes. } \\
\text { In connection with Type I FIBOs capital requirements are in line with the Principles as Type I } \\
\text { FIBOs are subject to on-going capital requirements that are roughly in line with Basel II, and to } \\
\text { timely reporting, including quarterly and monthly reports. } \\
\text { For all other categories the minimum capital requirement is flat. Given that investment advisers } \\
\text { are not allowed to hold clients' assets, the lack of a risk adjusted capital is not a gap under the } \\
\text { IOSCO Principles. In the case of asset managers (discretionary or collective-CIS), the risk that } \\
\text { such intermediaries face is operational. Prima facie the situation of Type II FIBOs is more difficult } \\
\text { to ascertain, as the FIEA refers to them as broker-dealers. The limitations in the type of assets for } \\
\text { which they can provide brokerage services, as well as the prohibitions on OTC derivatives and } \\
\text { underwriting, make their business model relatively simple. In practice, as per the information } \\
\text { received by the FSA Type II FIBOs are distributors of units of "funds" that invest in illiquid assets } \\
\text { (REITs, race horses, etc), which are of private offering. Thus the risk that they face is also } \\
\text { operational (arising from potential fraud or other types of business conduct violations). Thus from } \\
\text { the perspective of the IOSCO principle there is a gap in the capital requirements of both categories } \\
\text { of intermediaries. However given that the risks in both cases are operational (and mitigated in the } \\
\text { case of CIS managers by the requirement of a separate custodian) the assessors do not consider } \\
\text { this gap sufficiently broad to warrant a partly implemented grade. } \\
\text { However, the situation is different in connection with the obligation to have the financial }\end{array}$ \\
\hline
\end{tabular}




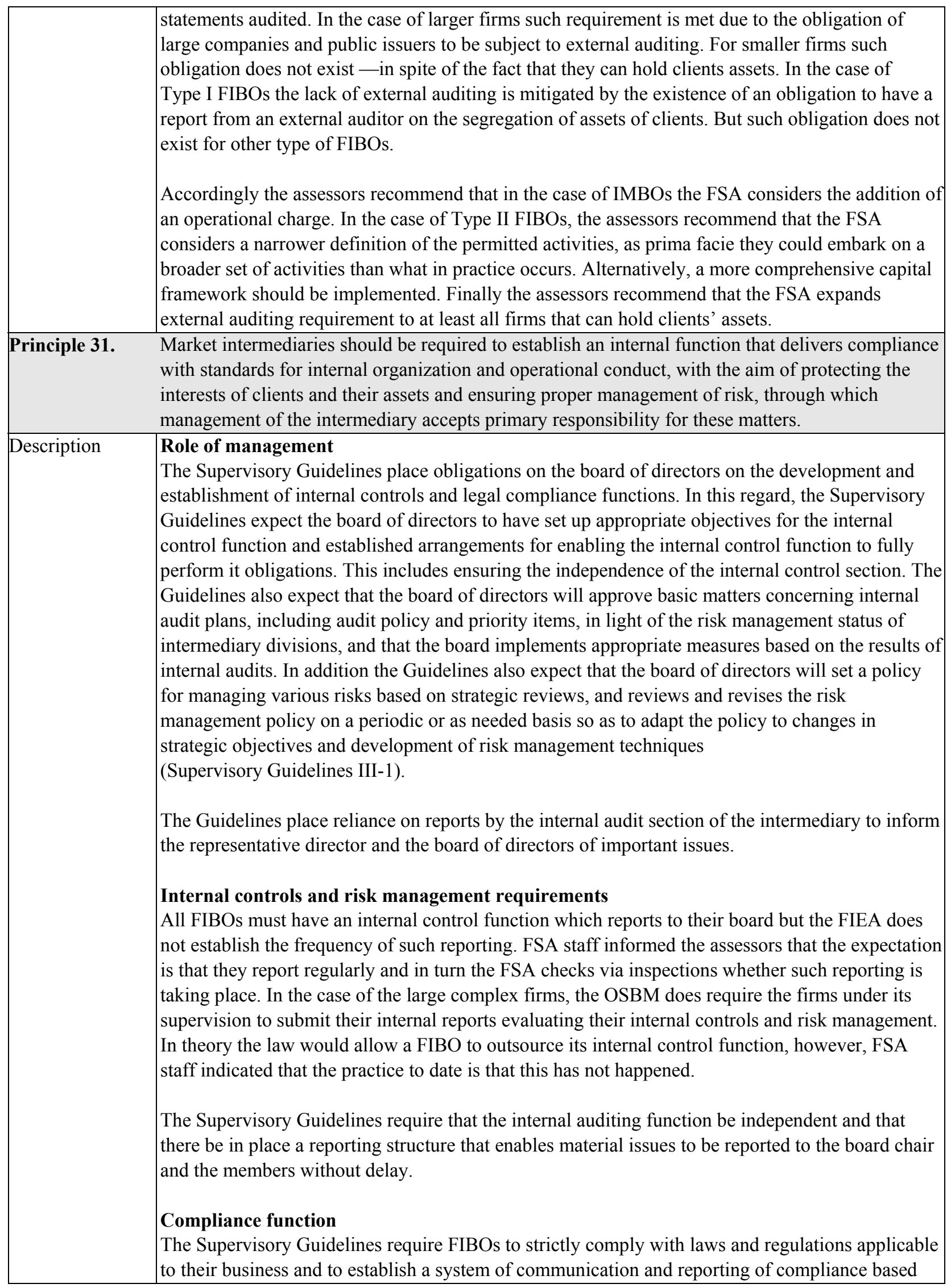


information to management within the business. For this purpose, FIBOs are required to establish divisions of managers in charge of compliance who must be independent of sales or asset management divisions (Supervisory Guidelines IV).

FIBOs are required to report immediately to the FSA when there is a breach of the law or regulations detected by the FIBO or its directors or officers (FIEA Article 50-8 Cabinet Order). In fact, the FIBOs submit reports to the FSA, which are followed up by the FSA.

\section{Management of conflicts of interest}

All FIBOs and their directors and employees are required to execute business in good faith and fairly to customers (FIEA Article 36). Conflicts of interest must be prevented and appropriate management structures (systems) to identify them and address them must be developed (FIEA Articles 36 and 44 and Supervisory Guidelines). In addition the Supervisory Guidelines require that a conflict of interest manager be appointed and that it be independent from the sales lines, and monitor the sales lines.

Under the Supervisory Guidelines, if the FSA considers that a conflict of interest management system is inadequate, an "order for improvement" can be issued.

If there is a likelihood that a customer's interests would be unduly harmed, the FSA can hold a hearing concerning the FIBO and require a report from it as to how it system complies with the obligation in its internal management system..

\section{Direct market access}

Clients are not permitted to have direct ("naked") electronic access to the markets as only members of an exchange are connected to the exchanges' trading systems and may conduct sales and purchases of securities and undertake market transactions in derivatives. However sponsored access is permitted. Exchanges regulations require members to have appropriate management systems. In practice FIBOs establish limits per client based on ratings and financial standing. The robustness of such "filters" is reviewed ex-post via on-site inspections by the JSDA/TSE and/or the FSA. In addition, the exchanges systems have a price limitation function, "tick" size limitations and circuit breakers to deal with excessive volatility.

\section{Clients assets}

FIBOs are required to manage client assets separately from their own property (FIEA Articles 42-4 and 43-2). Client money or securities must be deposited with a trust company (FIEA Article 43-2). Type I FIBOs are required to have an audit on clients' assets by a CPA or audit firm at least once a year (Cabinet Office Ordinance on Financial Instruments Business Article 142).

\section{Investors complaints}

FIBOs are required to have a person made responsible for handling investor complaints as part of the internal control function, at the branch level. Complaint details are to be reported to the head office compliance and dealt with. The FIBO is required to notify to the FSA complaints which indicate violations of law.

In addition, FIBO's are also required to develop appropriate control environments respectively for complaints and disputes in the financial ADR system. The distinction between complaints and disputes is under the Supervisory Guidelines considered to be relative and connected with each other. FIBOs must deal with complaints and disputes appropriately while taking into consideration their relativity and connections. FIBOs are required to develop internal control environments to deal with complaints made by customers in a prompt, fair and appropriate manner, including 
measures and responses required in the financial ADR system (Supervisory Guidelines III-2-5).

Ongoing discussions occur among FSA supervisory bureau, SESC, National Police Agency, ADR, associations, Consumer Agency and The National Consumer Affairs Center of Japan to ensure that client complaints are given prompt attention.

The Financial Instruments Mediation Assistance Centre (FIMAC), a financial ADR system, has been created for "simply and expeditiously" processing complaints and resolving disputes related to financial products and services. FIMAC conducts mediation of complaints arising from all types of intermediaries.

Know your customer obligations

Article 40(i) of the FIEA requires FIBOs to know their customers and prohibits them from conducting inappropriate business with them in light of the customers' knowledge, experience, assets and purpose in transacting business. FIEA also requires the maintenance of books and records (Article 46-2 and Cabinet Office Ordinance on Financial Instruments Business 157(2)), so all such customer information is required to be retained.

JSDA rules require its members to maintain relevant client details and to understand the customer's status and investment purpose ("know the customer"). The JSDA's requirements for account opening are onerous (16 specific procedures) requiring that a face to face meeting occur with a new client (one hour duration) and appropriate due diligence be undertaken regarding antimoney laundering due diligence and suitability for investment recommendations for the client.

In reaction to the development of complex products that have been offered to retail investors, the FSA has increased its supervision over suitability obligations. In particular it has set up a stricter suitability requirement in connection to complex products.

\section{Record- keeping obligations}

The Cabinet Resolution requires various types of documents (books and records) to be maintained by FIBOs for five to ten years.

\section{Information to be given to clients}

Customers must receive a document from a FIBO (before entering into a transaction) that outlines the contract and discloses fees and consideration payable by the customer (FIEA Article 37-3) and other relevant information to enable the client to make an informed investment decision. After a transaction is effected, customers receive a confirmation which sets out the contract date and names of the parties and other relevant particulars (FIEA Article 37-4).

FIBOs must provide clients with a statement of "outstanding balance of transactions" at least once a year (FIEA Article 37-4 and Cabinet Office Ordinance Article 98). In practice statements are given on a quarterly basis.

\section{Oversight of compliance with requirements set forth in this Principle}

Both off-site and on-site supervision are used by the FSA to monitor compliance with the obligations set forth in this Principle. As indicated on Principle 30 FIBOs are subject to different reporting obligations depending on their type. In addition they are subject to on-site inspections. The Supervisory Guidelines developed by the FSA are very thorough and address the review of all the issues included in this Principle. The opinion of participants is that the inspections carried out by the SESC are thorough and inspectors have the right skills. The files discussed with the SESC lead the assessors to the same conclusion. However an important challenge is the coverage of the 


\begin{tabular}{|c|c|}
\hline & $\begin{array}{l}\text { inspection program, as small Type I and IMBOs may go uninspected for long periods of time, and } \\
\text { type II FIBOs and investment advisors are only inspected on cause, as discussed in detail in } \\
\text { Principle } 12 \text {. } \\
\text { Inspections by SROs } \\
\text { As indicated in Principle 9, the JSDA conduct inspections on members which come to } \\
\text { complement the inspection program of the SESC, in particular in connection with larger firms. The } \\
\text { JSDA follows a risk based approach to determine the member firms to inspect. In this regard, the } \\
\text { key factors taken into consideration are: } \\
\text { - Capital adequacy (for regular members). } \\
\text { Past records of JSDA and SESC inspections. } \\
\text { Other information available (media, complaints). } \\
\text { Lines of business and customer profile. } \\
\text { The TSE also has an inspection program. Given that exchange members are also JSDA members, } \\
\text { the JSDA and the TSE have coordinated their enforcement programs, and in practice they conduct } \\
\text { joint inspections, whereby the TSE focuses on compliance with the rules and the JSDA focus on } \\
\text { compliance with JSDA rules. }\end{array}$ \\
\hline Assessment & Partly Implemented \\
\hline Comments & $\begin{array}{l}\text { Question } 19 \text { of the Methodology requires that the regulator has in place a supervision program that } \\
\text { seeks to monitor compliance of market intermediaries with their obligations. As indicated in } \\
\text { Principle } 12 \text { the coverage of the inspection program is limited, in particular for smaller Type I, and } \\
\text { IMBOs and all Type II and Investment Advisors - which are inspected mainly by cause. Such } \\
\text { limited coverage is a source of concern, in particular in light of the findings of the inspections } \\
\text { carried out by the SESC. Therefore, the partly implemented grade. } \\
\text { Question } 3 \text { of the IOSCO Methodology requires a market intermediary to be subject to an } \\
\text { objective periodic evaluation of its internal controls and risk management processes. The current } \\
\text { framework requires the existence of an internal control function, and the expectation is that such } \\
\text { function should periodically conduct such type of assessments. However, market participants } \\
\text { commented that fully independent functions exist mainly in the larger intermediaries, who do } \\
\text { conduct these types of assessments usually on an annual basis. In smaller firms such function is } \\
\text { not as developed. Thus the assessors encourage the authorities to explore mechanisms to } \\
\text { strengthen this function on smaller firms. }\end{array}$ \\
\hline Principle 32. & $\begin{array}{l}\text { There should be a procedure for dealing with the failure of a market intermediary in order to } \\
\text { minimize damage and loss to investors and to contain systemic risk. }\end{array}$ \\
\hline Description & $\begin{array}{l}\text { Early warning system } \\
\text { Type I } \\
\text { For Type I FIBO the FSA has established a double system that entails an early warning system and } \\
\text { an early correction system. If a Type I FIBO capital adequacy ratio falls below } 140 \text { percent } \\
\text { mandatory reporting is required (early warning) and if it falls below } 120 \text { percent the FSA } \\
\text { demands a plan to increase the ratio (early corrective action). The FSA may hold a hearing and } \\
\text { require detailed reporting of the situation thereby identifying the risks involved. It can also } \\
\text { conduct an inspection of the FIBO, if required. }\end{array}$ \\
\hline
\end{tabular}


Other FIBOs

For all other FIBOs, if the capital or the deposits for operation fall below the required minimum (refer to Principle 30), the FIBO must make a notification to the FSA and the situation is assessed. The FSA may utilize any of its powers in these circumstances. The FSA does not see this category as high risk.

Plan to deal with the failure of intermediaries and coordination with other authorities The FSA has not developed a plan to be followed in the event of an intermediary's failure. The FSA stored all relevant documents related to past bankruptcy cases, including those of large and complex securities firms, which keep a close record of specific procedures. This included the kind of cooperation FSA had with BOJ and court officials, the kind of business FSA ordered the firm to continue and suspend, the kind of information that had been released to the media and public, etc. The FSA believes that those documents work as precedents for dealing with the eventuality of a firm's failure, including a combination to restrain conduct, to ensure assets are properly managed and to provide information to the market as necessary. Accordingly, the FSA does not consider that there is additional benefit in preparing for internal use only, a plan which includes template documents, procedure manuals or guides to cover the types of issues that might arise in a failure/default scenario which would be routinely reviewed and updated as regulations and business activity change. Staff indicated that the FSA has been exchanging information and views with the BOJ to jointly prepare for a possible future financial crisis in the domestic financial market, and such discussions include necessary actions in case of an emergence of financial difficulties in potentially vulnerable firms.

A special case of cooperation concerns the supervisory college of one large entity which includes a crisis management group.

\section{Powers of the FSA}

The FSA has the power to order a market intermediary to change its methods of business, deposit its property, or take other measures it regards as necessary (Early Corrective Action, FIEA Article 51). It may cancel the intermediaries' registration, cancel its authorization, or order suspension of all or part of its business (FIEA Article 52). The FSA may request bankruptcy proceedings be commenced, or seek the appointment of an administrator and thereby control an intermediaries assets.

\section{Insolvency}

FIBOs are subject to the same regime as other entities, namely the procedure under the Bankruptcy Act and civil rehabilitation proceedings under the Civil Rehabilitation Act (similar to the U.S. Chapter 11 process).

The FSA can file for rehabilitation procedures and thereby can select a provisional administrator by filing for administrative order under the Act. The filing for administration orders needs to be made at the beginning of the rehabilitation procedures, therefore the FSA cannot file for administration orders without a basis of bankruptcy procedure initiation. A provisional administrator has the authority to manage and dispose of obligors' assets after the selection until the decision of initiation of the bankruptcy procedure. Permission of a court is needed when a provisional administrator makes a decision which is not within the scope of ordinary business of the affected firm.

In addition pursuant to Article 38 of the BOJ Act, on request of the PM and the MoF the BoJ could provide financial assistance to a securities firms, for purposes of ensuring financial stability. Such power has been used in the past by the BOJ in connection with the failure of Yamaichi. 


\begin{tabular}{|c|c|}
\hline & $\begin{array}{l}\text { Investors protection } \\
\text { Client assets are required to be managed separately by a FIBO from its own property (FIEA } \\
\text { Article } 43-2 \text { ). As stated in Principle } 31 \text {, in the case of Type I FIBOs an annual external audit is } \\
\text { required to check compliance with such obligation. } \\
\text { In the event of the insolvency of a FIBO, the FSA can issue an administrative order to protect } \\
\text { customers’ assets, including for example an order to return the segregated assets to the customers } \\
\text { promptly or to transfer the customers’ assets to other FIBO. (Article } 51-2 \text { of the FIEA). In } \\
\text { addition, Type I FIBOs are required to join an investor protection fund under which clients may be } \\
\text { refunded certain assets if they do not receive the total amount of their claims against the } \\
\text { intermediary (FIEA Article } 79-20 \text { ). The maximum reimbursement amount by the fund in the event } \\
\text { of bankruptcy of a firm is not more than ¥10 million per investor. The fund does not compensate } \\
\text { for loss to customers owing to decline of the securities holding prices. The Fund was established in } \\
2006 \text { and is funded by a compulsory contribution from its members. } \\
\text { Practice } \\
\text { The FSA recently was required to conduct prompt action in respect to Lehman Brothers Japan Inc. } \\
\text { by issuing orders to require the company to maintain assets in Japan. }\end{array}$ \\
\hline Assessment & Broadly Implemented \\
\hline Comments & $\begin{array}{l}\text { Question } 1 \text { of the methodology requires a clear plan to deal with the eventuality of a firms' failure. } \\
\text { The FSA has not developed a specific plan nor has it conducted other useful exercises such as } \\
\text { scenario analysis to be carried out along with the BOJ, in spite of the existence of large complex } \\
\text { firms. However, the assessors acknowledge that the authorities have documented with detail past } \\
\text { large failures domestic and international (such as Yamaichi, Sanyo and Lehman) and the responses } \\
\text { thereto and that there is a substantial written "corporate memory" available to current FSA } \\
\text { management to refer to and guide it should a firm failure occurs again. It is also acknowledged that } \\
\text { discussions with the BOJ are ongoing regarding action to be taken in respect of a future financial } \\
\text { crisis. In such context, the assessors recommend that the FSA continue to work jointly with the } \\
\text { BoJ in establishing plans to address the failure of large complex securities firms. } \\
\text { In addition, the assessors encourage the authorities to explore the development of a resolution } \\
\text { regime for large complex firms. The assessors acknowledge, however, that this is an area where } \\
\text { best practices have not developed yet and that discussions at the international level are on-going. }\end{array}$ \\
\hline \multicolumn{2}{|r|}{ Principles for the Secondary Markets } \\
\hline Principle 33. & $\begin{array}{l}\text { The establishment of trading systems including securities exchanges should be subject to } \\
\text { regulatory authorization and oversight. }\end{array}$ \\
\hline Description & $\begin{array}{l}\text { Types of regulated markets } \\
\text { There are two different types of regulated markets in Japan: } \\
\text { - A Financial Instruments Exchange (FIE) } \\
\text { - A Proprietary Trading System (PTS) } \\
\text { Exchanges } \\
\text { Under Article } 80 \text { of the FIEA a license needs to be obtained from the FSA to establish a FIE. } \\
\text { Under the legal framework such license must be granted by the MoFS on behalf of the PM. } \\
\text { However the review of the application is done at the FSA, which provides a recommendation to } \\
\text { the MoFS. } \\
\text { Licensing requirements } \\
\text { - Capital must not be less than } ¥ 1 \text { billion. (FIEA Article } 83-2 \text { and Cabinet Order for } \\
\text { Enforcement of FIEA Article 19). In addition CCPs themselves must be registered entities }\end{array}$ \\
\hline
\end{tabular}


(FIEA Article 156) and have capital of at least one billion JPY as per Cabinet Ordinance.

- Applicants must be "fit and proper" (no fines of applicant/officers/major shareholders in last five years, no license rescission) (FIEA Article82).

- Applicants must be able to demonstrate adequate articles of incorporation.

- Applicants must have operational and brokerage contract rules that conform to the laws and regulations that are sufficient for achieving "fair and smooth" sales and purchases of securities (and market transactions in derivatives, if applicable) as well as for the protection of investors.

- The applicant must have an appropriate personnel structure sufficient to operate a FIE and it must be organized as an exchange in an appropriate manner.

- An applicant's operational rules must contain detailed regulations relating to guarantee funds or clearing margins (FIEA Article 117).

There is a primary shareholder limitation of 20 percent maximum holding but local government can hold between 20-50 percent of an exchange. An authorized Financial Instruments Firms Association, an exchange or an exchange holding company is permitted to hold over 50 percent (FIEA Article 106-10). Authorization is required to establish an exchange holding company.

Licensing process

Relevant documents attached to the application are verified by staff of the Financial Markets Division of FSA. This includes a validation of the applicants' articles of incorporation, it's operational (listing and delisting of securities) and brokerage contract rules, it's personnel structure and the kind and type of transactions. The trading system is checked by staff to ensure conformity with the operational rules but an independent IT systems evaluation of the trading system is not required. Meetings are held with the applicant and although on-site visits could be conducted by FSA as part of the verification process in practice this does not occur until a periodic inspection is conducted, post licensing as required by the inspection process.

\section{Proprietary trading systems (PTS)}

A PTS can only be established by a FIBO (Type 1, FIEA Article 30). Authorization for this activity is required in addition to the requirement that a FIBO be registered. Such authorization is also pursuant to a verification process by FSA staff, similar to that for exchanges.

Authorization criteria

The criteria to be taken into account for authorization are a combination of the obligations set in FIEA and also set out in the Cabinet Office Ordinance (see for example Article 17(12)) obligations to establish appropriate rules.

- These include the methods to manage risk of loss and methods to "decide" business.

- Capital must exceed $¥ 300$ million which is substantially higher than the base requirement for a Type I FIBO of $¥ 50$ million.

A PTS is required to be examined and reported on concerning its IT infrastructure by an independent expert without any conflict of interest (FIEA Article 30-3 and Cabinet Office 
Ordinance Article 18(4)).

Authorization process

Before grant of authorization, the FSA is required to validate whether an appropriate system and regulations have been developed and are included in its operational rules including trading, management of risks of loss, whether the applicant has sufficient capital and resources and whether documents attached to the application sufficiently describe its business methodology, including segregation of operations and settlement procedure for traded securities. Validation is conducted by staff of the Securities Business Division, Supervisory Bureau of FSA. The FSA does not conduct an on-site visit during the validation process, however it relies on the report by the independent third party on the IT systems of the PTS (see comment above).

\section{On-going compliance with requirements}

The licensing or authorization criteria, respectively, continue to apply after authorization. The FSA does not require exchanges or PTS to submit an annual assessment report, nor does the FSA have a process to formally assess compliance criteria on an annual basis.

However, an exchange is obliged to report to the FSA the condition of system management and maintenance on a monthly basis. If changes occur, this must be documented in the report. Also, exchanges are required to notify outages to the FSA immediately. In addition, Article 151 of the FIEA provides the FSA with the authority to order the production of a report or conduct an inspection. This power has been used recently by the FSA, as the TSE migrates its future market to a new platform. In such context the FSA has required progress reports from the TSE.

There is no specific ongoing requirement for a PTS to provide an IT report on a periodic basis; however PTS are required to report any operational incident to the JSDA and the FSA. In addition, as FIBOs, operators of PTS are subject to inspections programs by JSDA and the SESC.

Authorization is required of any amendments to the articles of incorporation, operational or brokerage contract rules, of an exchange (FIEA Article 149). Listing of securities or financial instruments or suspensions or lifting of trading suspensions requires notification to the FSA (FIEA Articles 121 and 128).

A PTS is required to notify and obtain registration from the FSA of any change (FIEA Article 31) of any of the criteria for registration (except its category of business, in respect of which other provisions apply).

\section{Fairness of access}

Exchanges are prohibited from providing unjust discriminatory treatment to a member (FIEA Article 87-9). To assess such requirement the operational rules of the exchange must contain detailed regulations relating to trading participants (FIEA Article 117). Fairness of access is examined as part of the review of the exchange's application and any amendment after licensing is also reviewed for this purpose. In this regard for purposes of providing co-location facilities both the TSE and OSE discussed fair access previously with the FSA.

In respect of a PTS fair market access is also verified as part of the authorization process (Cabinet Office Ordinance Article 17 (12)) as are any subsequent amendments to relevant rules.

\section{Operational information (Record keeping, Access to information)}

Exchanges are required (by the criteria of licensing) to keep trading records to permit them to reconstruct past trading activity and to do so in a reasonable time. The FSA has access to such 


\begin{tabular}{|c|c|}
\hline & $\begin{array}{l}\text { information. } \\
\text { A PTS is required to prepare and preserve "books and documents" to also include trading records } \\
\text { (FIEA Article 46-2 and } 3 \text { ). } \\
\text { Exchanges trade data and quote information is available to all members on real time. It is also } \\
\text { available to the market via distribution services such as FLEX and API. Trading information on a } \\
\text { PTS (pre and post trade) is disclosed via JSDA publicly via its web site. }\end{array}$ \\
\hline Assessment & Fully Implemented \\
\hline Comments & $\begin{array}{l}\text { The FSA and the market consider it unlikely that a new competitor exchange will seek approval } \\
\text { since consolidation of existing exchanges has commenced with the announcement of the } \\
\text { agreement to combine managements of the TSE and the OSE (by January 2013). In such context, } \\
\text { the assessors do not see as a major concern the lack of a requirement for a detailed IT systems } \\
\text { assessment, in the context of licensing of exchanges. Also, given that in the past the MoFS has } \\
\text { relied on the technical recommendations of the FSA, the assessors do not see as a major concern } \\
\text { the fact that the licensing and de-licensing of exchanges is retained by the PM, but exercised by } \\
\text { the MoFS. } \\
\text { The assessors note that in the past there had been concerns about the reliability of the IT systems } \\
\text { of the TSE. The TSE migrated it equity market to arrowhead in 2010. Participants expressed } \\
\text { favorable views on the reliability of this new platform. }\end{array}$ \\
\hline Principle 34. & $\begin{array}{l}\text { There should be ongoing regulatory supervision of exchanges and trading systems which should } \\
\text { aim to ensure that the integrity of trading is maintained through fair and equitable rules that strike } \\
\text { an appropriate balance between the demands of different market participants. }\end{array}$ \\
\hline Description & $\begin{array}{l}\text { Market surveillance by the Exchanges or TSE SRO } \\
\text { Exchanges and TSE SRO are responsible for real time surveillance of the markets. The key } \\
\text { objective of such monitoring is to ensure orderly trading. In addition, they also support SESC } \\
\text { functions in regard to the detection of unfair trading practices via surveillance on t+1. To do that } \\
\text { the exchanges have automated mechanisms, with alerts imbedded on them. } \\
\text { The TSE employs } 50 \text { people to monitor unfair trading practices, manipulation of the market and } \\
\text { insider trading. Any suspicious trading activity will be examined by the exchange, against price } \\
\text { volume movements in the market, price sensitive announcements, patterns of trading and general } \\
\text { market intelligence received. If necessary a preliminary investigation will be conducted and the } \\
\text { TSE would be able to request information from members. However if information from third } \\
\text { parties is required, then cases are referred to the SESC as exchanges do not have compulsory } \\
\text { powers over third parties. OSE market surveillance conducts similar type of surveillance and } \\
\text { employs } 25 \text { people. } \\
\text { The exchanges carry an important number of investigations each year in connection with unfair } \\
\text { trading practices. For example, in } 2010 \text { the TSE concluded } 149 \text { investigation reports, while in } \\
\text { 2009 it concluded } 220 \text { investigations reports in connection with suspicions of unfair trading } \\
\text { practices. Such reports are scrutinized by the SESC staff to determine whether further action is } \\
\text { needed, including opening up its own investigation. } \\
\text { There is a formal agreement between the exchanges to co-operate and share information. The } \\
\text { exchanges meet five times a year to exchange information about market issues. However in } \\
\text { practice, in what relates to the cash markets, the TSE concentrates roughly } 90 \text { percent of trading } \\
\text { volumes. } \\
\text { There is more active cooperation between the TSE and the OSE in order to monitor for potential }\end{array}$ \\
\hline
\end{tabular}


problems across the cash and derivatives markets, and contacts in such case occur more regularly via phone. In the case that the exchanges identify a potential case of market manipulation they communicate it to the SESC. The SESC provided examples of investigations of potential market manipulation across the markets.

Market surveillance by the SESC

The SESC and the local finance bureaus conduct surveillance on $t+1$ with the overall objective of detecting unfair trading practices.

The SESC uses intelligence received from exchanges' market monitoring, information received from intermediaries and from the public to detect unfair trading practices. The SESC systems do not generate intraday alerts, but the SESC does use certain factors (similar to those used in an alert system) as the basis for its market surveillance.

Various sources of information are available to the SESC:

- Real time information from vendors, as well as SCAN-IPS (internet patrol system) as web based "crawler" to identify information about the market or chat rooms.

- A "reception desk" to receive information from the public and on average 7000 items of information (each is documented) is received annually from this source.

- In addition a system called "Compliance WAN" uses a dedicated line connected to the network nationwide of securities firms with national securities exchanges, the JSDA, the SESC and with the Local Finance Bureaus, to electronically transfer transaction data. The new "Compliance WAN" system began operation on January 26, 2009, and it can now be used by market surveillance staff of the SESC from their desk PCs.

The SESC uses its SCAN system (developed in house) to consolidate and analyze data obtained from the exchanges, the JSDA and FIBOs (including data on PTS) via Compliance WAN. The system allows it to review bids and offers by security, by client name and by volume and price.

In 2010 the SESC and the local finance bureaus conducted 691 early-stage investigations, and in 2009 it conducted 749 early-stage investigations related to unfair trading practices. In particular, the SESC has conducted selected reviews of trading between markets that offer the same or similar products.

Oversight of regulated markets by the FSA/SESC

\section{Off site}

Exchanges

There are several mechanisms for off-site supervision.

- There are regular (separate) monthly meetings between the SESC and the larger exchanges, TSE and OSE.

- Exchanges are required to submit a monthly report on their activities including trading.

- Exchanges report not just on anomalous trading but on their business affairs including financial and prudential matters, and settlement figures.

- In addition there is an annual report, including audited financial statements (audit is required 


\begin{tabular}{|c|c|}
\hline & 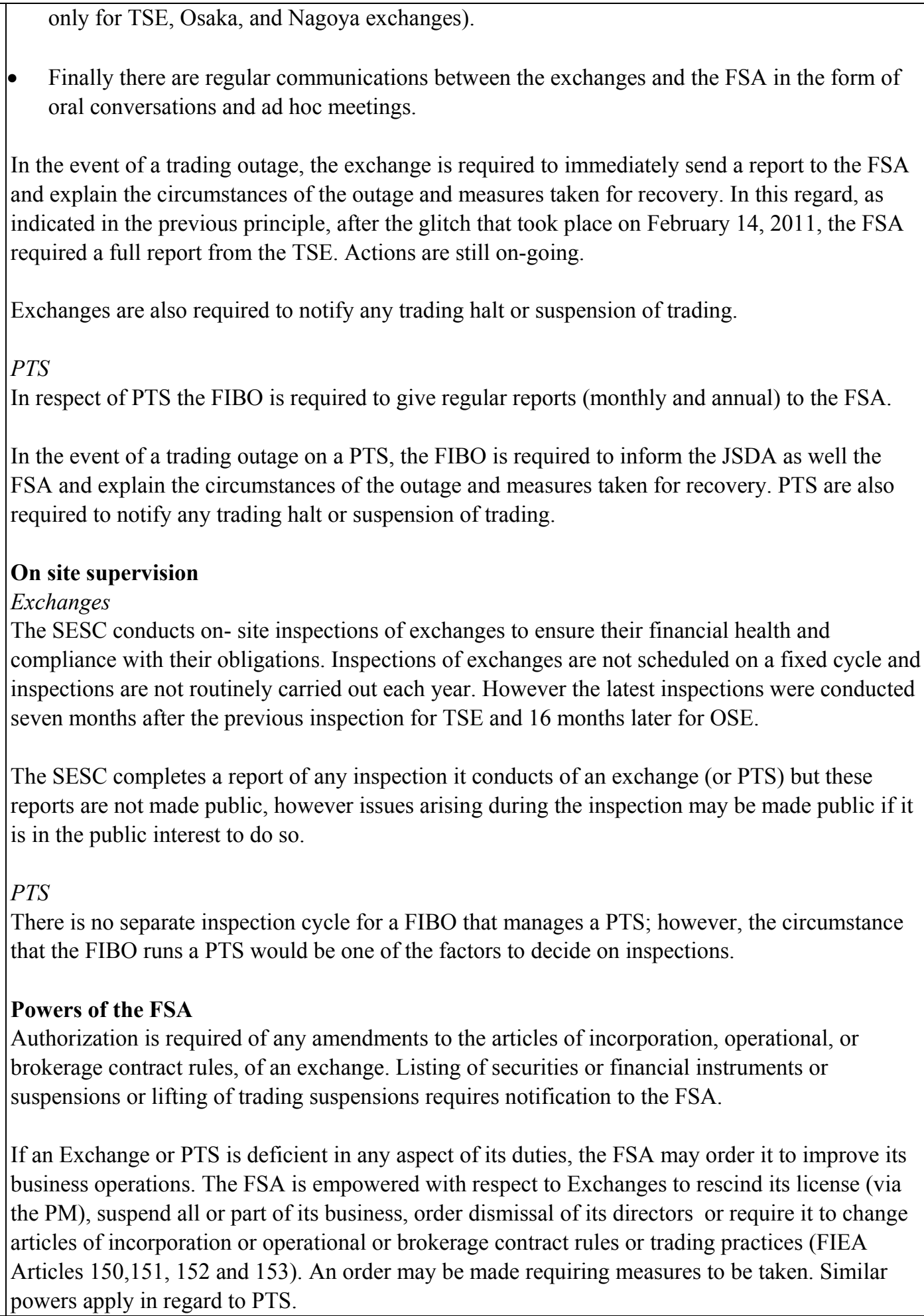 \\
\hline Assessment & Fully Implemented \\
\hline Comments & -- \\
\hline Principle 35. & Regulation should promote transparency of trading. \\
\hline Description & $\begin{array}{l}\text { Transparency } \\
\text { Exchanges }\end{array}$ \\
\hline
\end{tabular}




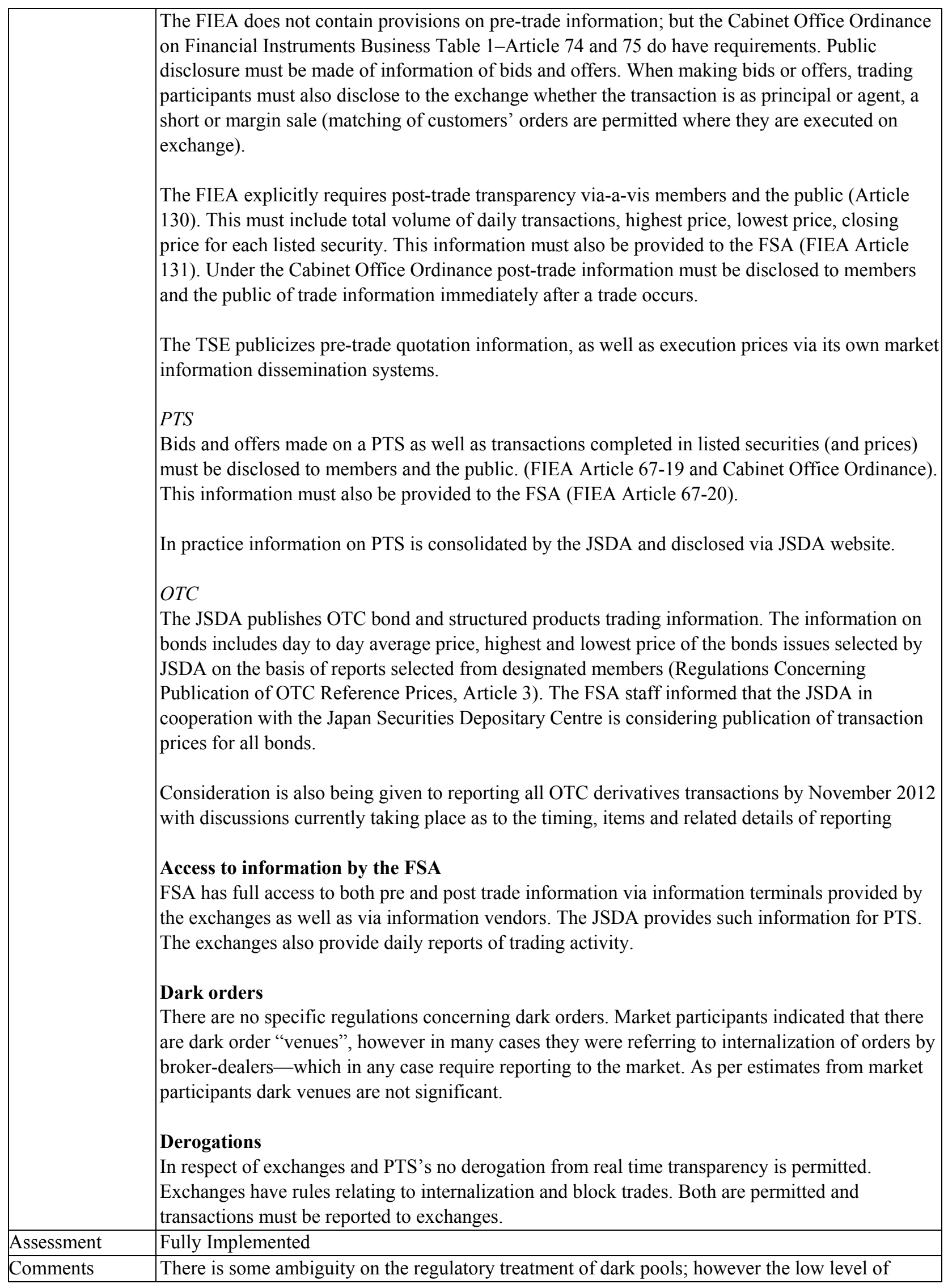




\begin{tabular}{|c|c|c|c|}
\hline & \multicolumn{3}{|c|}{ activity leads to conclude that this point is not a cause of major concern. } \\
\hline Principle 36. & \multicolumn{3}{|c|}{ Regulation should be designed to detect and deter manipulation and other unfair trading practices } \\
\hline \multirow[t]{7}{*}{ Description } & \multicolumn{3}{|c|}{$\begin{array}{l}\text { Misconduct } \\
\text { The FIEA imposes both administrative and criminal penalties for a set of unfair practices listed in } \\
\text { the FIEA. Administrative money penalties by way of fine depend on the nature of the offence } \\
\text { under a formula approach (for insider trading or market manipulation repeat offenders can be } \\
\text { levied additional amounts under a "surcharge payment order"). }\end{array}$} \\
\hline & & Administrative Infraction & Criminal offenses \\
\hline & $\begin{array}{l}\text { Market and price } \\
\text { manipulation }\end{array}$ & $\begin{array}{l}\text { Article 174- } 2 \text { formula. } \\
\text { Aggregate of (i) the profit or loss } \\
\text { during the period of the violation } \\
\text { and (ii) the difference between } \\
\text { the value of sales (purchases) } \\
\text { until the end of the violation and } \\
\text { the value appraised using the } \\
\text { lowest (highest) price during the } \\
\text { one month after the violation }\end{array}$ & $\begin{array}{l}\text { Article } 197 \text { penalty } \\
\text { imprisonment not more than } \\
10 \text { years or fine of not more } \\
\text { than } ¥ 10 \text { million or both (but } \\
\text { maximum fine of } ¥ 30 \text { million } \\
\text { if act done for property } \\
\text { benefit) }\end{array}$ \\
\hline & $\begin{array}{l}\text { Spread rumors and } \\
\text { make false } \\
\text { quotations } \\
\text { (including false } \\
\text { statements) }\end{array}$ & $\begin{array}{l}\text { Article } 173 \text { formula. Difference } \\
\text { between the value of sales } \\
\text { (purchases) until the end of the } \\
\text { violation and the value appraised } \\
\text { using the lowest (highest) price } \\
\text { during the one month after the } \\
\text { violation) }\end{array}$ & $\begin{array}{l}\text { Article } 197 \text { penalty } \\
\text { imprisonment not more than } \\
10 \text { years or fine of not more } \\
\text { than } ¥ 10 \text { million or both ( but } \\
\text { maximum fine of } ¥ 30 \text { million } \\
\text { if act done for property } \\
\text { benefit) }\end{array}$ \\
\hline & Insider dealing & $\begin{array}{l}\text { Article } 175 \text { formula. Difference } \\
\text { between the value of sales } \\
\text { (purchases) related to the } \\
\text { violation (limited to those made } \\
\text { during the six months prior to the } \\
\text { publication of material facts) and } \\
\text { the product of the lowest } \\
\text { (highest) price during the two } \\
\text { weeks after the publication of } \\
\text { material facts and he volume of } \\
\text { such sales (purchase) }\end{array}$ & $\begin{array}{l}\text { Article } 197-2 \text { penalty } \\
\text { imprisonment not more than } \\
\text { five years or fine of not more } \\
\text { than } ¥ 5 \text { million or both }\end{array}$ \\
\hline & $\begin{array}{l}\text { Wrongful acts and } \\
\text { using fraudulent } \\
\text { means }\end{array}$ & & $\begin{array}{l}\text { Article } 197 \text { penalty } \\
\text { imprisonment not more than } \\
10 \text { years or fine of not more } \\
\text { than } ¥ 10 \text { million or both } \\
\text { (but maximum fine of } \\
¥ 30 \text { million if act done for } \\
\text { property benefit) }\end{array}$ \\
\hline & \multicolumn{3}{|c|}{$\begin{array}{l}\text { Mechanisms to detect unfair trading practices } \\
\text { Market surveillance by the SESC and the exchanges and on-site inspections by the SESC, the } \\
\text { JSDA and the exchanges, described in Principles } 12 \text { and } 35 \text { are the main mechanisms used by the } \\
\text { authorities to detect unfair trading practices. Administrative sanctions (money penalties) imposed } \\
\text { and criminal referrals are summarized below. }\end{array}$} \\
\hline
\end{tabular}




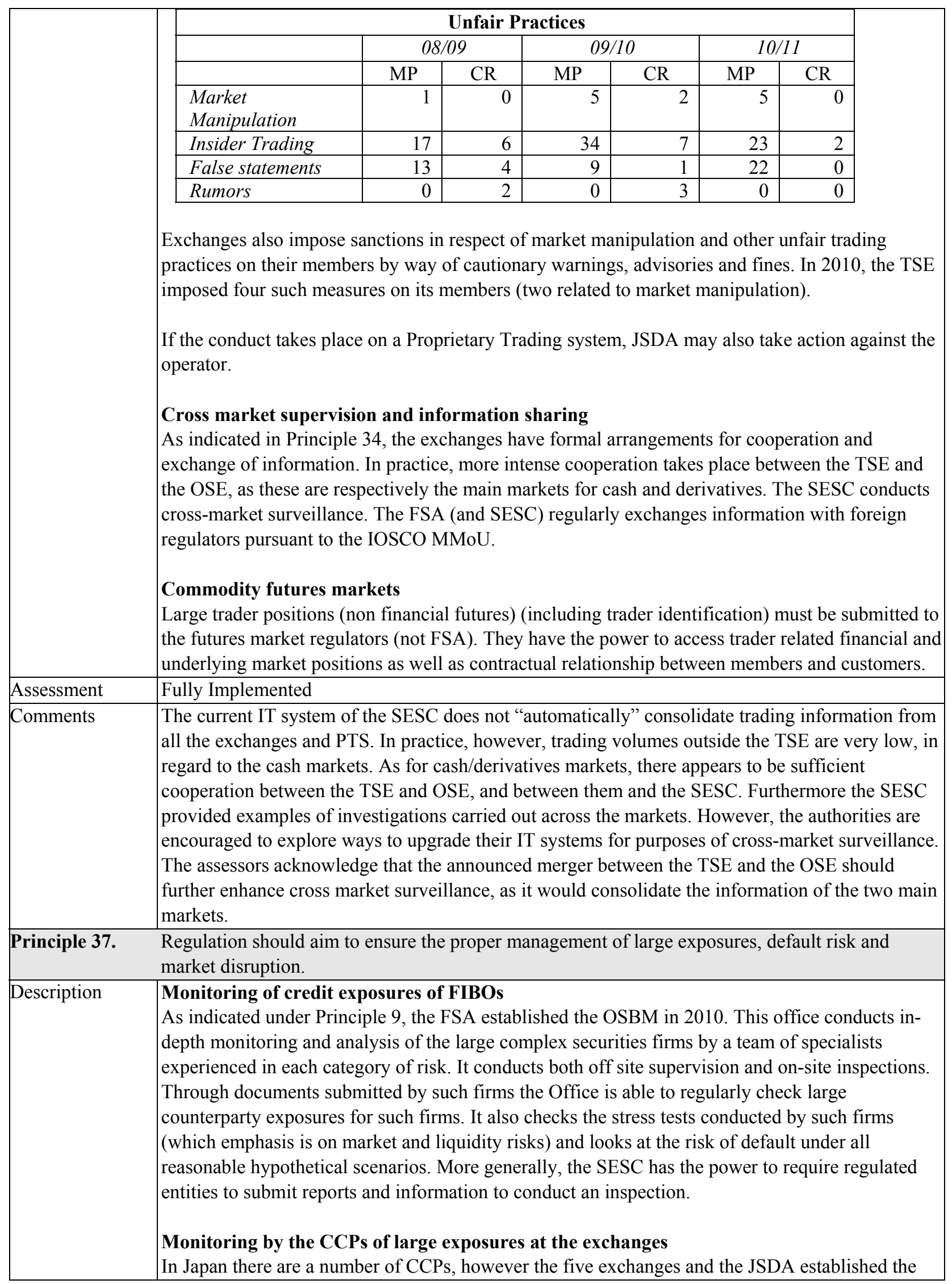


Japan Securities Clearing Corporation (JSCC) in 2003 to consolidate clearing of securities transactions that used to be performed separately by individual cash markets. The JSCC also clears for three PTS as well as futures and option transacted on TSE (and OTC derivatives markets). As JSCC assumes obligations for cash market transactions it monitors the risks as counterparty to the transactions, including in the event of default of the clearing participant. OSE internally clears and settles trades on its market.

The FIEA (FIEA Article 156) requires a CCP to be licensed as a Financial Instruments Obligation Assumption Service, have appropriate business rules (including a clearing deposit) and to establish procedures of collateral management and monitor large exposures and monitor the exposures of clearing members. Members which have excessive exposures against their net capital or who have deteriorating credit are required to increase their margins. Any amendment of the business rules (or articles of incorporation) requires FSA authorization (FIEA Article 156-12).

In its function as CCP, the OSE (and the JSCC) have established criteria for clearing participants, which include minimum capital requirements, a capital ratio and a consolidated capital to risk ratio. Clearing members are also required to contribute to a settlement fund, based on their trading volumes.

Both the OSE and JSCC monitor unsettled positions on a daily basis. Although no "hard limits" are imposed, "soft" position limits operate via collateral and margin arrangements under which, maximum loss calculations are regularly undertaken to ensure that exposures are manageable.

When they find high levels of risk they have the power to:

- Request a report from the participant when the estimated amount of position risk exceeds a certain ratio (depending on the type of transaction).

- Require increased collateral.

- If derivatives are involved, instruct the participant to reduce its exposure or provide more margin/collateral to the CCP. If this does not occur new trades will not be permitted (but existing trades will be settled normally).

- The FSA is informed twice daily by the OSE/JSCC of the bigger positions members hold together with commentary about the positions.

\section{Default procedures}

Detailed default procedures are required by the FIEA to be contained in the business rules of a CCP (FIEA Article 156). Procedures must cover liquidation on the failure of a clearing participant, including calculation of the amount of open positions.

In the event of a default by a participant, the OSE (or the JSCC) would first suspend the delivery of settlement funds and securities to the defaulter while at the same time selling the securities in respect of which delivery was suspended. If necessary, the settlement fund would be used, based on loss sharing rules that are known to clearing members (and available in the websites of the TSE and OSE). Both CCPs have liquidity facilities with settling banks to secure short term liquidity.

\section{Large traders report}

Currently CCPs receive information from clearing members only on a net basis. However, the FSA is in a position to request more granular information based on its general powers over 


\begin{tabular}{|c|c|}
\hline & 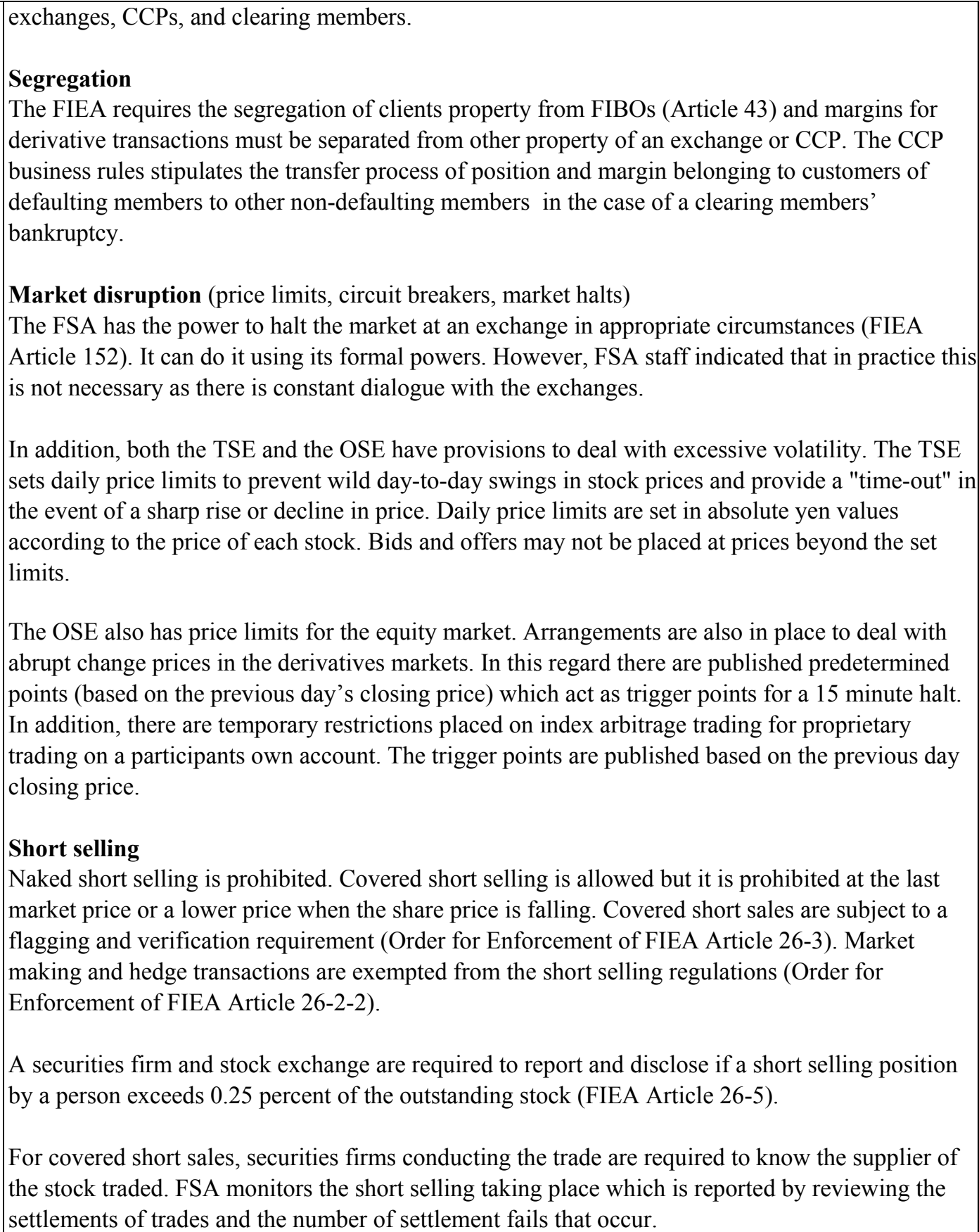 \\
\hline Assessment & Fully Implemented \\
\hline Comments & -- \\
\hline & Principles Relating to Clearing and Settlement \\
\hline Principle 38. & $\begin{array}{l}\text { Securities settlement systems and central counterparties should be subject to regulatory and } \\
\text { supervisory requirements that are designed to ensure that they are fair, effective and efficient and } \\
\text { that they reduce systemic risk. }\end{array}$ \\
\hline Description & -- \\
\hline Assessment & Not assessed \\
\hline Comments & -- \\
\hline
\end{tabular}

